\title{
21. PHYSICAL PROPERTIES OF DEEP-SEA SEDIMENTS FROM THE PHILIPPINE SEA AND SEA OF JAPAN
}

\author{
Arnold H. Bouma, Department of Oceanography, Texas A\&M University, College Station, Texas \\ and \\ J. Casey Moore, Earth Sciences, University of California, Santa Cruz, California
}

\section{INTRODUCTION}

Physical property data were routinely collected on cores recovered during DSDP Leg 31 in the Philippine Sea and Sea of Japan. This paper synthesizes the density, porosity, water content, and vane shear collected in this region. These data are not only of geotechnical significance, but also provide sensitive indicators of physical and chemical diagenesis. It behooves geologists to pay attention to physical properties as they provide quantitative support for many macroscopic to ultra microscopic observations on the sediment-rock transformation.

Wet-bulk density was routinely determined during Leg 31 on at least two sections per core by the Gamma Ray Attenuation Porosity Evaluation (GRAPE). Onboard an analog record was produced from which calculations were made for the shipboard reports. The data were also stored on magnetic tape which was processed later via the DSDP facilities. Occasionally a cylinder sample was collected for grain density analyses on shore. Those data were then utilized to correct the assumed grain densities used for the GRAPE. In addition, 1-cc syringe collected samples were taken onboard for direct laboratory analyses of water content, density, and porosity.

Discussions on these measurements are given and/or evaluations have been previously presented (Gealy, 1971; Bennett and Keller, 1973; Boyce, 1973c; Manheim et al., 1974). In addition, a number of memoranda and instructions to the shipboard scientists written by Boyce (1972a, b, c; 1973a, b, d, e; 1974 a, b) present the techniques and the derivation of formulas.

The wide variety of lithologies recovered during Leg 31 provided an opportunity to study the variation of shear strength with sediment type over depths of several hundred meters. These data are compiled by site, and comparisons are made by sediment type.

\section{METHODS, DEFINITIONS, AND EQUATIONS}

In the following section some brief notes are given on the methods and evaluations of techniques used, on the definitions of the parameters, and on the equations utilized. Three groups of analyses can be distinguished: (1) water content, density, and porosity via the gravimetric methods; (2) density and porosity via the GRAPE method; and (3) vane-shear measurements.

\section{Gravimetric Methods}

No salt corrections are applied in all these techniques. The samples are either collected with a 1-cc syringe for analyses onboard ship, with a cylinder to provide data for the GRAPE computer program, via a chunk of material if the sediment is too stiff for the syringe method, or in small bottles for home base analyses.

\section{Water Content}

Two types of water content data are distinguished: the wet-water content (used throughout this paper) and the dry-water content. These parameters are defined as follows:

Wet-water content $(\%)=$

$\frac{\text { (weight wet sediment)-(weight dry sediments }+ \text { salts) }}{\text { (weight wet sediment) }} \times 100$

$$
=\frac{\text { (weight of evaporated water) }}{\text { (weight of wet sediment) }} \times 100
$$

$\begin{aligned} & \text { Dry-water } \\ & \text { content }(\%)\end{aligned}=\frac{\text { (weight of evaporated water) }}{\text { (weight of dry sediment }+ \text { salts) }} \times 100$

If salt corrections ( $\left.35 \mathrm{ppt} @ 21^{\circ} \mathrm{C}\right)$ are desired, a factor of 1.0363 may be used with the wet-water content, for example: wet-water content with salt correction = $1.0363 \times$ water content without salt correction (Boyce, 1973a, b; 1974a).

The water content of a 1-cc syringe collected sample was obtained onboard ship. According to Boyce (1974a) the absolute error is about $\pm 2 \%$. This technique can only be applied when dealing with soft sediments which enable the investigator to fill the syringe properly. When this is not successful, a chunk of sample is collected. Not having a known volume is not important when measuring water content.

Occasionally a cylinder sample, about $2 \frac{1}{2} \mathrm{~cm}$ in diameter and $2 \frac{1}{2} \mathrm{~cm}$ high, was collected by the marine technician on watch. This sample is analyzed on shore, and the results are used for the computer program of the magnetic tape GRAPE data. The senior author collected a number of larger samples (about 40-50 cc) in glass bottles for home base analyses. By using large samples and a stable balance, a high accuracy can be obtained.

\section{Wet-Bulk Density}

Bulk density or wet unit weight is defined as the ratio of the total weight of the sediment mass to the total volume of the sediment mass irrespective of the degree of saturation (Cernock, 1970). If all voids are filled with 
water, the bulk density in $\mathrm{g} / \mathrm{cc}$ can be calculated according to the equation:

$$
\text { Wet-bulk density in } \mathrm{g} / \mathrm{cc}=\frac{\text { weight of wet sediment }}{\text { volume of wet sediment }}
$$

Salt corrections are not required according to Boyce (1973b, 1974b). For these analyses it is vital that the syringe is properly filled and that the volume removed for weighing is cut off very accurately. The volume of 1 cc actually is too small to obtain the accuracies required (Bennett and Keller, 1973). The bottle samples, mentioned under water content, provide much more accurate data.

\section{Porosity}

This parameter is defined as the ratio in \% of the volume of voids to the total volume of the sediment mass (Cernock, 1970) and it can be calculated from the water content if grain density is known (or can be estimated, and assuming $100 \%$ saturation). The porosity can also be obtained from the syringe technique data as follows (no salt correction):

Porosity in $\%=\frac{100}{1.00 \mathrm{~g} / \mathrm{cc}} \times \frac{\text { weight of evaporated water }}{\text { volume of wet sediment }}$

\section{Grain Density}

The definition of grain density in $\mathrm{g} / \mathrm{cc}$ is the weight of the mineral grains divided by their volume. This parameter should be calculated from data obtained by the pycnometer method (Boyce, 1973b). Grain density can be calculated as an approximation from the wetbulk density and the porosity. This is not precise, and it results in a large scatter of data, especially when high porosities are involved. The grain density, including slats, is obtained as follows:

Grain density in $\mathrm{g} / \mathrm{cc}=$

(weight of dry sediment + salts)

(volume of evaporated water) (100/porosity)-(volume of evaporated water)

\section{GRAPE Methods}

The GRAPE analog data in the form of magnetic digital tape, was computer processed according to Boyce $1973 \mathrm{c}$ (note typographical error in step 2 of Whitmarsh, program on p. 1118 where $\rho_{\mathrm{wt}}$ should be $\rho_{\mathrm{wz}}$. Boyce, personal communication).

Sample data, however, were calculated differently than the GRAPE analog data, as follows: gamma rays of a specific energy level are absorbed or scattered when they travel through a core, and the attenuation is related to the density of the sample (Evans, 1965; Harms and Choquette, 1965; Boyce, 1973c). The amount of intensity that is registered can be calculated as follows:

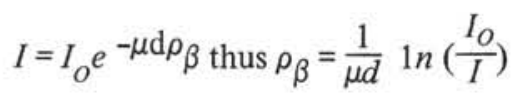

where

$I$ is the intensity of the gamma ray beam penetrating the sample with no loss of energy.
Io is the source intensity.

$\mu$ is the mass attenuation coefficient in $\mathrm{g} / \mathrm{cc}$. Unless the attenuation coefficient of the material is known, the mass attenuation coefficient is $0.100 \mathrm{~g} / \mathrm{cc}$. $d$ is the thickness or diameter of the sample in $\mathrm{cm}$. $\rho \beta$ is the bulk density in $\mathrm{g} / \mathrm{cc}$.

When dealing with porous materials, the above equation becomes (Evans, 1965; Harms and Choquette, 1965; Schlumberger, 1966):

$$
\rho_{\beta}=\rho_{g}(1-\phi)+\rho_{f}(\phi)
$$

where

$\rho g$ is the matrix or grain density. Normally the value $2.65 \mathrm{~g} / \mathrm{cc}$, the density of quartz, is used. Feldspar and clay densities range from 2.56 to 2.72 , calcite 2.71 , and dolomite averages $2.85 \mathrm{~g} / \mathrm{cc}$. Due to the mixed mineralogy the calculations were based on $2.65 \mathrm{~g} / \mathrm{cc}$.

$\phi$ is the porosity or volume/liquid content when the material is completely liquid saturated.

$\rho f$ is the density of the fluid filling the pores. The GRAPE value $1.125 \mathrm{~g} / \mathrm{cc}$ was used. However, the $\rho \beta$ will be in error because the interstitia water attenuation coefficient is greater than that of quartz. Therefore, the analog GRAPE data were processed through the Whitmarsh Iteration for proper adjustment which is equivalent to the following for the sample data:

Assign $\rho f=$ true density seawater $=1.025 \mathrm{~g} / \mathrm{cc}$ Therefore, true wet-bulk density $=\rho \beta t$ :

$$
\rho_{\beta t}=\rho_{g}(1-\phi)+\rho_{f}(\phi)
$$

When combining both bulk-density equations, an equation for porosity is obtained. Using the abovementioned values, the following simple equation can be derived:

$$
\begin{aligned}
& \phi=\left(\rho_{g}-\frac{1 n I_{O} / I}{\mu d}\right) /\left(\rho_{g}-\rho_{f}\right) \\
& \phi=\left(\rho_{g}-\frac{1}{\mu d} \ln \frac{I_{O}}{I}\right) /\left(\rho_{g}-\rho_{f}\right) \\
& \phi=\left(\rho_{g}-\rho_{\beta}\right) /\left(\rho_{g}-\rho_{f}\right)=\frac{2.65-\rho \beta}{1.525}
\end{aligned}
$$

\section{VANE SHEAR}

Shear strength was determined manually with a "Torvane shear device." The vane shear was rotated at a rate of $10^{\circ}-20^{\circ} / \mathrm{sec}$. All measurements were made by the authors. Repeated determinations by the same or different operators varied by less than $15 \%$. Measurements were made in the least-disturbed portions of the cores, usually near their base and normally on vertical surfaces. All plotted data are from sediment in the clayey silt, silty clay, or clay grain size.

Vane-shear test values provide a measure of sediment cohesion and approximate shear strength determined from unconfined (or confined undrained) triaxial tests. 
In this paper only raw values are presented. Lee (1973) has made corrections on vane-shear measurements from North Pacific deep-sea sediments in order to approximate in situ conditions. He finds that the estimated in situ strengths are higher by a factor of 2 or 3 than the laboratory measurements. The uncorrected vane-shear data presented in this paper are referred to simply as shear strength.

\section{GRAPE COUNT VARIATIONS, DRIFT CHARACTERISTICS, AND COMPARISON WITH ANALOG RECORDS}

Two slices of rock from Core 8 (Hole 290) were measured on the GRAPE unit for 2 min according to the count method. The results are presented in Table 1, which not only reveals the variation within one core section of this polymict debris flow deposit (Pluenneke and Bouma, this volume), but also the drift of the equipment.

Two sets of counts were made at slightly different spots on a plan-parallel slice from Piece \#1 which is the top piece of Section 1. Eight measurements were carried out at randomly selected spots on a slice from Piece \#2 of Section 5. In addition, four repetitive counts were conducted on the same location in this latter slice to find drift characteristics of the unit when measuring inhomogeneous natural material.

Table 1 shows that the drift in the GRAPE system, when the sample is not moving, varies between 6464 and 6651 counts/sec. This is a variation of 187 counts/sec or $2.85 \%$ of the average. The drift is $1.50 \%$ in the direction of the highest count and $1.39 \%$ to the lowest value. Applying these percentage variations to the average number of counts/sec of Piece \#2 of Section 5, only 4 counts are higher and 2 counts lower than the range covered by the variation. This means that $50 \%$ of the counts fall within that variation and $50 \%$ can be real since the sediment is polymict in nature. The variation is too large to allow conclusions to be drawn about the variations when calculating the resulting densities and porosities.

When comparing these data with the count values obtained from complete core segments, it can be seen that both result in comparable density values. Section 2 has a coarse sandy texture and visually and radiographically is more homogeneous than the much coarser Section 5. This may account for the difference in variation and the difference in counts/sec for both samples.

Instead of using a polymict sediment to study drift characteristics of the GRAPE, the present authors made measurements on a standard aluminum bar with four different thicknesses (1, 1.5, 2, and 2.625 in.) (Table 2). This bar is assumed to be homogeneous, and variations should refer to drift within the unit. The first four measurements in Table 2 were done without moving the bar. The following groups of counts were made while the bar was moving slowly in a horizontal direction. Theoretically, each set of counts covers the same part of the aluminum bar. Table 2 also shows the total variation obtained per groups of counts.

The drift measured when the bar is not moving is much larger than any variation obtained on one thickness from a moving bar. The percentage of variation is higher than the similar one given in Table 1. No comparison can be made between data from the moving and the nonmoving bar. It seems that the variation in number of counts/sec decreases with increasing diameter of the aluminum bar. This may indicate that the accuracy of the measurements increases with a decrease in the length of the air path the gamma rays

TABLE 1

GRAPE Count Measurement on Two Sediment Slices From Core 8, Hole 290. Based on 2 Minute Counting

\begin{tabular}{|c|c|c|c|c|c|c|}
\hline $\begin{array}{l}\text { Section- } \\
\text { Piece }\end{array}$ & $\begin{array}{l}\text { Thickness } \\
\text { (cm) }\end{array}$ & $\begin{array}{l}\text { Counts } \\
\text { per Sec }\end{array}$ & $\begin{array}{l}\text { Average } \\
\text { Counts per } \\
\text { Sec }\end{array}$ & $\begin{array}{l}\text { Bulk } \\
\text { Density } \\
\text { (g/cc) }\end{array}$ & $\begin{array}{c}\text { Porosity } \\
(\%)\end{array}$ & Remarks \\
\hline $1-1$ & $\begin{array}{l}1.6256 \\
1.6256\end{array}$ & $\left.\begin{array}{l}6911 \\
6872\end{array}\right]$ & 6892 & $\begin{array}{l}2.10 \\
2.14\end{array}$ & $\begin{array}{l}36 \\
33\end{array}$ & $\begin{array}{l}\mathrm{D} \\
\mathrm{D}\end{array}$ \\
\hline \multirow[t]{3}{*}{$5-2$} & $\begin{array}{l}1.7018 \\
1.7018 \\
1.7018 \\
1.7018 \\
1.7018 \\
1.7018 \\
1.7018 \\
1.7018\end{array}$ & $\left.\begin{array}{l}6649 \\
6610 \\
6647 \\
6236 \\
6394 \\
6437 \\
6366 \\
6478\end{array}\right]$ & 6477 & $\begin{array}{l}2.23 \\
2.27 \\
2.24 \\
2.61 \\
2.46 \\
2.42 \\
2.49 \\
2.39\end{array}$ & $\begin{array}{l}27.5 \\
25 \\
26.8 \\
2.6 \\
12 \\
15 \\
10 \\
17\end{array}$ & $\begin{array}{l}\text { D } \\
\text { D } \\
\text { D } \\
\text { D } \\
\text { D } \\
\text { D } \\
\text { D } \\
\text { D }\end{array}$ \\
\hline & $\begin{array}{l}1.7018 \\
1.7018 \\
1.7018 \\
1.7018\end{array}$ & $\left.\begin{array}{l}6464 \\
6651 \\
6548 \\
6548\end{array}\right]$ & 6553 & 2.40 & 16 & $\begin{array}{l}\mathrm{S} \\
\mathrm{S} \\
\mathrm{S} \\
\mathrm{S}\end{array}$ \\
\hline & 1.7018 & & $6486^{a}$ & $2.38^{\mathrm{a}}$ & $17.7^{\mathrm{a}}$ & \\
\hline
\end{tabular}

Note: D indicates that counts were done at different spot from previous one; $\mathrm{S}$ indicates that counts were done at same spot as previous one.

atotal average of Piece 2 from Section 5. 
TABLE 2

GRAPE Counts on Standard Aluminum Bar With Four Different Diameters as Used for Calibration Purposes

\begin{tabular}{|c|c|c|c|c|c|c|}
\hline $\begin{array}{l}\text { Thickness } \\
\text { (cm) }\end{array}$ & $\begin{array}{l}\text { Counts } \\
\text { per } 2 \mathrm{sec}\end{array}$ & $\begin{array}{l}\text { Average } \\
\text { counts } \\
\text { per } 2 \mathrm{sec}\end{array}$ & $\begin{array}{l}\text { Average } \\
\text { Density } \\
(\mathrm{g} / \mathrm{cc})\end{array}$ & $\begin{array}{l}\text { Total V } \\
\text { (counts } \\
\text { per } 2 \\
\text { sec) }\end{array}$ & $\begin{array}{l}\text { riation } \\
\text { (as \% } \\
\text { of the } \\
\text { average) }\end{array}$ & Remarks \\
\hline $\begin{array}{l}2.54 \\
2.54 \\
2.54 \\
2.54\end{array}$ & $\begin{array}{l}4786 \\
4686 \\
4633 \\
4638\end{array}$ & 4686 & 2.874 & 153 & 3.27 & $\begin{array}{l}\text { Bar } \\
\text { not } \\
\text { moving }\end{array}$ \\
\hline $\begin{array}{l}2.54 \\
2.54 \\
2.54\end{array}$ & $\begin{array}{l}4798 \\
4767 \\
4762\end{array}$ & 4776 & 2.799 & 36 & 0.75 & $\begin{array}{l}\text { Bar } \\
\text { moving }\end{array}$ \\
\hline $\begin{array}{l}3.81 \\
3.81 \\
3.81\end{array}$ & $\begin{array}{l}3365 \\
3359 \\
3353\end{array}$ & 3359 & 2.790 & 12 & 0.36 & $\begin{array}{l}\text { Bar } \\
\text { moving }\end{array}$ \\
\hline $\begin{array}{l}5.08 \\
5.08 \\
5.08\end{array}$ & $\begin{array}{l}2380 \\
2386 \\
2382\end{array}$ & 2383 & 2.768 & 6 & 0.25 & $\begin{array}{l}\text { Bar } \\
\text { moving }\end{array}$ \\
\hline $\begin{array}{l}6.6675 \\
6.6675 \\
6.6675\end{array}$ & $\begin{array}{l}1556 \\
1563 \\
1560\end{array}$ & 1560 & 2.747 & 7 & 0.49 & $\begin{array}{l}\text { Bar } \\
\text { moving }\end{array}$ \\
\hline
\end{tabular}

Note: Mean bulk density for the aluminum bar from these figures is $2.796 \mathrm{~g} / \mathrm{cc}$. Density given by Boyce $(1973 \mathrm{c}, 1973 \mathrm{e})$ is $2.71 \mathrm{~g} / \mathrm{cc}$.

have to travel. The distance between the gamma ray source and the scintillation detector is fixed. Accuracy could be improved if the distance of travel through air was fixed, that is, if the cores were of uniform diameter. The analog densities are practically always lower than those obtained from count data.

\section{TEST RESULTS}

For geographical as well as lithological purposes, the 12 sites from Leg 31 have been placed into two groups: the Philippine Sea (Sites 290-298) and the Sea of Japan (Sites 299-302). Bulk density, porosity, and water content have been determined by GRAPE and syringe methods on most sites, while vane shear has only been measured at Sites 293, 294, 295, 296, 297, 298, 299, and 302 .

\section{Site 290}

This site was placed at the distal edge of a sedimentary apron. A significant portion of the sedimentary column was deposited below the carbonate compensation depth and preceded by volcanic debris that have undergone postdepositional alteration.

The upper 90 meters consist predominantly of brown silt-bearing clays, locally becoming silt/zeolite-rich or containing zeolite-rich volcanic ash beds. From 90 to 139 meters the sediments are yellow to medium brown nannofossil oozes, increasing in volcanic ash downward. Locally some radiolarian-bearing/clay-rich zones were observed. From 139 to 225 meters the sediments are mainly zeolite-bearing/ash-rich nannofossil oozes. The bottom part, cored to a depth of 255 meters, consists of volcanic conglomerate containing subangular to subrounded clasts of diabase, volcanic alteration products, and glass in a micrite matrix.

The physical properties vary considerably due to the nature of the material as well as to the degree of coring disturbance. Core 1 was too watery to allow any measurements. Cores 2-6 were dry and core cutting resulted in microruptures which affected the syringe sampling accuracy. Cores 7 and 8 were well indurated.

The data are given in Table 3 and Figure 1. Scattering is large and increase/decrease of bulk density/porosity is small from Cores 1 to 7. A rapid change can be noted in Core 8. The computer plot from the GRAPE data shows little due to a compressed horizontal scale. In Figure 1 the same symbol is used for count method results on pieces from Core 8 as for the syringe method data for the upper seven cores.

\section{Site 291}

Two holes, 291 and 291A, were drilled at this site. Five lithologies were distinguished starting with a siltrich zeolite clay in the upper 69 meters. From 69 to 80 meters a nannofossil ooze was encountered, followed by a clayey radiolarian ooze of late Eocene age to a depth of about 99 meters. This was underlain by a nannofossilradiolarian-bearing clay changing to a ferruginous, zeolite-rich clay. From 118 to 126.5 meters a finegrained basalt was drilled.

Few measurements on physical properties were obtained. In most cases the analog record could easily be averaged (Table 4, Figure 2), however, when consistent offsets were recognized, smaller intervals were averaged. The bulk densities thus obtained for Core 5 (Hole 291) were very unreliable due to fragmentation of the material. Therefore, a number of pieces were subjected to the count method. A difference of $0.1-0.2 \mathrm{~g} / \mathrm{cc}$ was obtained between analog record averaging and count computation, which is within the order of magnitude for technical errors.

A minor, but rather consistent increase in bulk density from 1.28 to $1.42 \mathrm{~g} / \mathrm{cc}$ was observed in the upper four cores of Hole 291. The basaltic material from Core 5 
TABLE 3

Bulk Density, Porosity, and Water Content as Determined by the GRAPE and Syringe Methods, Site 290

\begin{tabular}{|c|c|c|c|c|c|c|c|c|c|c|c|}
\hline \multirow[b]{3}{*}{ Core } & \multirow[b]{3}{*}{ Section } & \multirow{3}{*}{$\begin{array}{l}\text { Diameter } \\
\text { (in.) }\end{array}$} & & & \multirow[b]{3}{*}{ Lithology } & \multicolumn{2}{|c|}{ GRAPE } & \multicolumn{3}{|c|}{ Syringe } & \multirow{3}{*}{ Remarks $^{b}$} \\
\hline & & & \multicolumn{2}{|c|}{ Interval $(\mathrm{cm})$} & & \multirow{2}{*}{$\begin{array}{c}\text { Bulk } \\
\text { Density } \\
\text { (g/cc) }\end{array}$} & \multirow{2}{*}{$\begin{array}{l}\text { Porosity } \\
\text { (\%) }\end{array}$} & \multirow{2}{*}{$\begin{array}{c}\text { Water } \\
\text { Content } \\
(\%)\end{array}$} & \multirow{2}{*}{$\begin{array}{l}\text { Bulk } \\
\text { Density } \\
(\mathrm{g} / \mathrm{cc})\end{array}$} & \multirow{2}{*}{$\begin{array}{c}\text { Porosity } \\
\text { (\%) }\end{array}$} & \\
\hline & & & GRAPE $^{\mathrm{a}}$ & Syringe & & & & & & & \\
\hline 1 & 1 & 2.6 & A & 66 & Silty clay & 1.38 & 83.6 & 61.29 & 1.35 & 82.66 & \\
\hline \multirow[t]{5}{*}{2} & 2 & 2.6 & A & & Clayey & 1.39 & 82.9 & & & & \\
\hline & 3 & & & $0-6$ & Clayey & & & 69.18 & 1.26 & 87.03 & \\
\hline & & & & $0-6$ & Clayey & & & 68.81 & 1.28 & 87.93 & \\
\hline & 4 & 2.6 & A & 77 & Clayey with volc. ash & 1.39 & 82.9 & 61.78 & 1.36 & 84.20 & \\
\hline & 5 & 2.6 & A & & Clayey with volc. ash & 1.41 & 80.9 & & & & \\
\hline \multirow[t]{2}{*}{3} & 2 & 2.6 & A & 74 & Nanno and rad ooze & 1.42 & 80.9 & 59.12 & 1.32 & 78.17 & \\
\hline & 3 & 2.6 & A & $0-6$ & Nanno ooze & 1.41 & 80.9 & 52.94 & 1.40 & 74.10 & \\
\hline 4 & 2 & 2.6 & A & 85 & Nanno ooze & 1.46 & 78.3 & 54.70 & 1.32 & 72.20 & \\
\hline \multirow[t]{5}{*}{5} & 1 & & & 83 & Nanno ooze with clay & & & 55.28 & & & Chunk method \\
\hline & & & & $144-150$ & Nanno ooze with clay & & & 55.46 & 1.38 & 76.41 & Experimental \\
\hline & 2 & 2.3 & A & $143-150$ & Nanno ooze with clay & 1.43 & 80.3 & 52.29 & & & Experimental \\
\hline & 3 & 2.3 & $0-75$ & & Nanno ooze with clay & 1.47 & 77.6 & & & & \\
\hline & & 2.3 & $75-150$ & & Nanno ooze with clay & 1.67 & 64.5 & & & & \\
\hline \multirow[t]{2}{*}{6} & 2 & 2.3 & A & & Clay-ash-nanno ooze & 1.50 & 75.7 & & & & \\
\hline & 3 & 2.3 & A & & Nanno volc. ash & 1.50 & 75.7 & & & & \\
\hline \multirow[t]{8}{*}{7} & 1 & & & $138-150$ & Nanno volc. ash & & & 44.44 & 1.25 & 55.70 & Experimental \\
\hline & & & & $138-150$ & Nanno volc. ash & & & 48.81 & 1.46 & 68.46 & Experimental \\
\hline & & & & $138-150$ & Nanno volc. ash & & & 43.97 & 1.37 & 60.43 & Experimental \\
\hline & 2 & 2.3 & $0-75$ & & Nanno volc. ash & 1.51 & 75.0 & & & & \\
\hline & & 2.3 & $75-150$ & & Nanno-rich volc. ash & 1.58 & 70.4 & & & & \\
\hline & 3 & 2.3 & A & & Nanno-rich volc. ash & 1.56 & 71.7 & & & & \\
\hline & 4 & 2.3 & A & & Nanno volc. ash & 1.56 & 71.7 & & & & \\
\hline & & & Piece no. & & & & & GRA & E count $\mathrm{r}$ & thod & \\
\hline \multirow[t]{22}{*}{8} & 1 & 2.33 & 2 & & Volc. conglomerate & 2.09 & 36.8 & & 2.13 & 34 & \\
\hline & & 2.32 & 3 & & Volc. conglomerate & 2.09 & 36.8 & & 2.08 & 37 & \\
\hline & & 2.32 & 4 & & Volc. conglomerate & 2.07 & 38.2 & & 2.15 & 32.7 & \\
\hline & & 2.32 & 5 & & Volc. conglomerate & 2.14 & 33.6 & & 2.17 & 31 & \\
\hline & 2 & 2.32 & 1 & & Volc. conglomerate & 2.06 & 38.8 & & 2.07 & 38 & \\
\hline & & 2.32 & 14 & & Volc. conglomerate & 2.10 & 36.2 & & 2.24 & 26.8 & \\
\hline & & 2.33 & 16 & & Volc. conglomerate & 2.12 & 34.9 & & 2.17 & 31 & \\
\hline & & 2.30 & 19 & & Volc. conglomerate & 2.17 & 31.6 & & 2.24 & 26.8 & \\
\hline & 3 & 2.32 & 4 & & Volc. conglomerate & 2.23 & 27.6 & & 2.34 & 20 & \\
\hline & & 2.33 & 9 & & Volc. conglomerate & 2.23 & 27.6 & & 2.27 & 25 & \\
\hline & & 2.32 & 11 & & Volc. conglomerate & 2.04 & 40.1 & & 2.12 & 34.7 & \\
\hline & & 2.32 & 12 & & Volc. conglomerate & 2.06 & 38.8 & & 2.12 & 34.7 & \\
\hline & & 2.32 & 14 & & Volc. conglomerate & 2.18 & 30.9 & & 2.27 & 25 & \\
\hline & & 2.32 & 15 & & Volc. conglomerate & 2.20 & 29.6 & & 2.27 & 25 & \\
\hline & & 2.32 & 17 & & Volc. conglomerate & 2.16 & 32.2 & & 2.23 & 27.5 & \\
\hline & 4 & 2.30 & 4 & & Volc. conglomerate & 2.11 & 35.5 & & 2.19 & 20 & \\
\hline & & 2.32 & 6 & & Volc. conglomerate & 2.31 & 22.4 & & 2.39 & 17 & \\
\hline & & 2.32 & 17 & & Volc. conglomerate & 2.31 & 22.4 & & 2.39 & 17 & \\
\hline & & 2.30 & 18 & & Volc. conglomerate & 2.56 & 5.9 & & 2.66 & - & \\
\hline & 5 & 2.30 & 1 & & Volc. conglomerate & 2.39 & 23.0 & & 2.49 & 10 & \\
\hline & & 2.34 & 6 & & Volc. conglomerate & 2.41 & 15.8 & & 2.47 & 11 & \\
\hline & & 2.335 & 15 & & Volc. conglomerate & 2.53 & 7.9 & & 2.60 & 3 & \\
\hline
\end{tabular}

${ }^{\mathrm{a}} \mathrm{A}=$ average reading from the GRAPE analog record.

${ }^{b}$ Experimental $=$ all weighings made on triple beam balance. Volume was determined by subtracting the weight in water from the wet weight. 


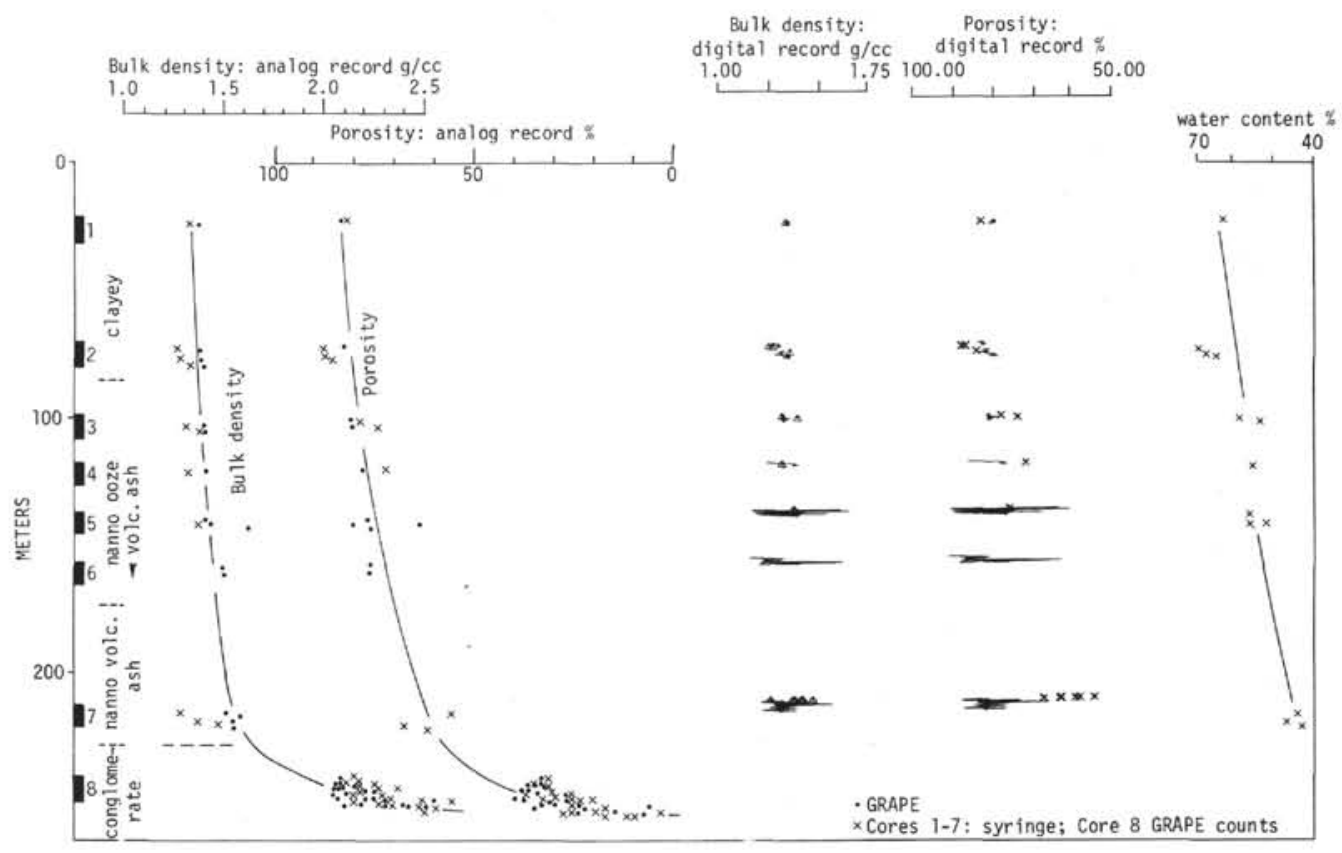

Figure 1. Plot of physical properties for Site 290. GRAPE analog record readings as well as computer plot are presented in addition to laboratory analyses (syringe and chunk methods).

On the left the cores are given as black rectangles and the general lithology.

TABLE 4

Bulk Density, Porosity, and Water Content as Determined by the GRAPE and Syringe Methods, Site 291

\begin{tabular}{|c|c|c|c|c|c|c|c|c|c|c|c|}
\hline \multirow[b]{3}{*}{ Core } & \multirow[b]{3}{*}{ Section } & \multirow{3}{*}{$\begin{array}{l}\text { Diameter } \\
\text { (in.) }\end{array}$} & & & \multirow[b]{3}{*}{ Lithology } & \multicolumn{2}{|c|}{ GRAPE } & \multicolumn{3}{|c|}{ Syringe } & \multirow[b]{3}{*}{ Remarks } \\
\hline & & & \multicolumn{2}{|c|}{ Interval $(\mathrm{cm})$} & & \multirow{2}{*}{$\begin{array}{c}\text { Bulk } \\
\text { Density } \\
(\mathrm{g} / \mathrm{cc})\end{array}$} & \multirow{2}{*}{$\begin{array}{l}\text { Porosity } \\
\text { (\%) }\end{array}$} & \multirow{2}{*}{$\begin{array}{c}\text { Water } \\
\text { Content } \\
(\%)\end{array}$} & \multirow{2}{*}{$\begin{array}{c}\text { Bulk } \\
\text { Density } \\
(\mathrm{g} / \mathrm{cc})\end{array}$} & \multirow{2}{*}{$\begin{array}{c}\text { Porosity } \\
(\%)\end{array}$} & \\
\hline & & & GRAPE $^{a}$ & Sy ringe & & & & & & & \\
\hline 1 & 1 & \multirow{4}{*}{2.6} & \multirow{4}{*}{ A } & \multirow{3}{*}{$\begin{array}{c}140 \\
144-150\end{array}$} & \multirow{10}{*}{$\begin{array}{l}\text { Silty zeolite clay } \\
\text { Silty zeolite clay } \\
\text { Nanno ooze } \\
\text { Clayey rad ooze } \\
\text { Clay } \\
\text { Zeolite-rich clay } \\
\text { Rad zeolite clay } \\
\text { Rad zeolite clay } \\
\text { Cherty clay } \\
\text { Cherty clay } \\
\text { Zeolite clay }\end{array}$} & \multirow{4}{*}{1.28} & \multirow{4}{*}{89.8} & 56.92 & 1.38 & 78.5 & \multirow{14}{*}{$\begin{array}{l}\text { Count method } \\
\text { Count method }\end{array}$} \\
\hline \multirow[t]{2}{*}{2} & 1 & & & & & & & 56.52 & 1.41 & 79.8 & \\
\hline & 2 & & & & & & & & \multirow[b]{2}{*}{1.19} & \multirow[b]{2}{*}{90.2} & \\
\hline 3 & 1 & & & 136 & & & & 76.02 & & & \\
\hline & 3 & 2.6 & 0.70 & & & 1.33 & 86.6 & & & & \\
\hline & & 2.6 & $90-125$ & & & 1.37 & 83.9 & & & & \\
\hline & & 2.6 & $130-150$ & & & 1.42 & 80.7 & & & & \\
\hline & 4 & 2.6 & A & $0-6$ & & 1.37 & 83.9 & 46.28 & 1.49 & 68.8 & \\
\hline & & & & $0-6$ & & & & 56.64 & 1.31 & 74.2 & \\
\hline & & & & 88 & & & & 62.10 & 1.31 & 81.4 & \\
\hline \multirow[t]{4}{*}{5} & 2 & 2.34 & $\begin{array}{l}\text { Piece no. } \\
4\end{array}$ & & Basalt & 2.96 & & & & & \\
\hline & 2 & $\begin{array}{l}2.34 \\
0.27\end{array}$ & $\stackrel{4}{7 \mathrm{~A}-1}$ & & $\begin{array}{l}\text { Basalt } \\
\text { Basalt }\end{array}$ & $\begin{array}{l}2.96 \\
3.04\end{array}$ & & & & & \\
\hline & & 2.35 & 16 & & Basalt & 2.82 & & & & & \\
\hline & & 2.35 & 16 & & Basalt & 3.01 & & & & & \\
\hline
\end{tabular}

${ }^{a_{A}}=$ average reading from the GRAPE analog record.

reveals a much higher density $(2.82-2.87 \mathrm{~g} / \mathrm{cc}$ on the analog record and $2.96-3.04 \mathrm{~g} / \mathrm{cc}$ via the count method).

The water content values vary between $46 \%$ and $76 \%$ in the upper four cores with no apparent pattern. The value seems out of proportion in Core 3, presumably due to the sloppy consistency as a result of drilling distortion.

The porosities and water content show a reversal in a downward direction. With increase in radiolarian content an increase in porosity and water content can be observed. If this is real or artificial cannot be determined here.

\section{Site 292}

Site 292 was drilled to a depth of 443.5 meters through 367.5 meters of nannofossil ooze and chalk. The upper 154 meters consist of ooze, from 154-225 meters the sediment consists of nannofossil ooze with interbedded nannofossil chalk, while the bottom 142.5 meters were made up of nannofossil chalk with minor interbeddings of nannofossil ooze and cherty concretions. Below this, starting with Core 40 a sequence of exceptionally uniform intersertal to subophitic tholeiitic basalts were drilled. 


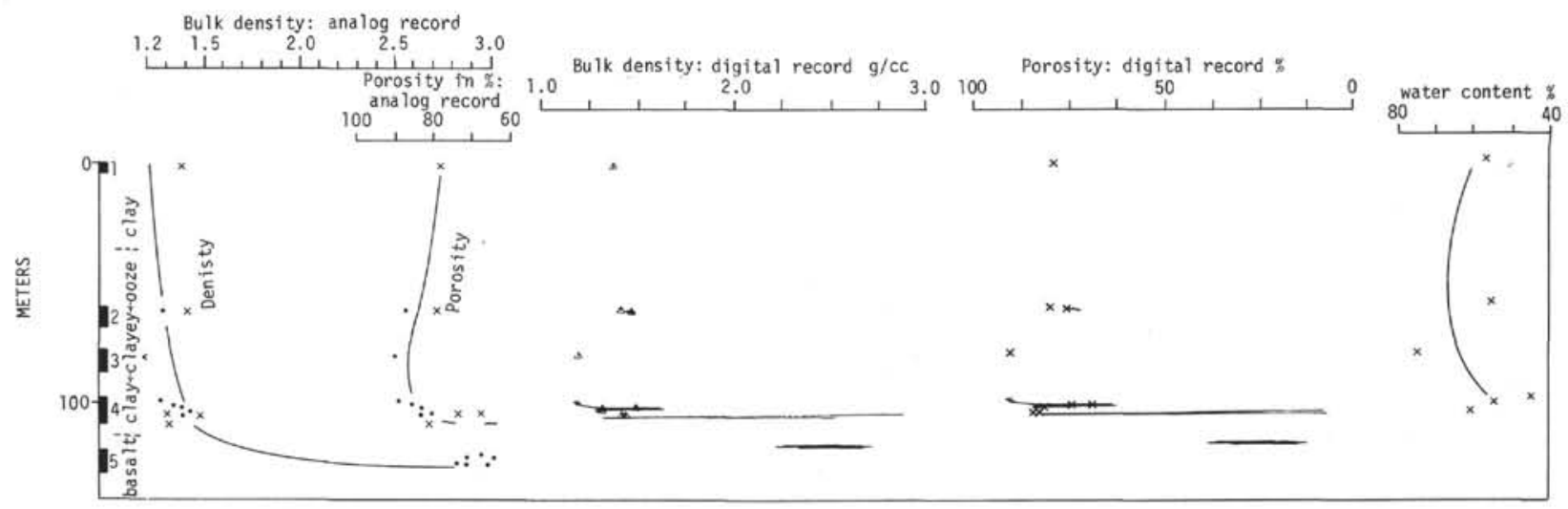

Figure 2. Plot of physical properties for Site 291. GRAPE analog record readings as well as computer plot are presented in addition to laboratory analyses (syringe and chunk methods). On the left the cores are given as black rectangles and the general lithology.

Most of the core sections were homogeneous enough to allow averaging of the GRAPE analog curve. Except for a few points, the scattering of data (Table 5, Figure 3 ) is small in the upper 160 meters. With increase in induration, an increase of irregularities can be observed (Table 5) and a larger scattering (Figure 3). Variations in the amount of foraminifera, radiolarians, clay, and volcanic ash primarily account for the variations in bulk density and porosity. It is also in this sediment packet, between 275 and 265 meters, that the increase of the mean bulk density is not associated with a decrease in water content.

With a few minor exceptions the laboratory-derived bulk density values are always lower than the GRAPE analog readings. Part can be due to drift in the GRAPE, but most differences must be a result of the syringe/chunk method which collects too small a sample to be completely representative of the larger part of the core or section. In addition, it is difficult to collect a good syringe sample from the easily ruptured ooze and chalk.

Figure 3 shows a steady, but small, increase/decrease of the bulk density/porosity with depth.

\section{Site 293}

Drilling and interval coring were carried out at Site 293 to a depth of 563.5 meters. Eighteen cores were recovered from the sediment column overlying basalt. No sediment was recovered from Core 1.

The sediment column consists of clay with sand, sandy silt, sandy clay, silty clay, and clayey silt intercalations as is common for a turbidite type series. With depth in the hole there is a decrease of the coarser components. The basaltic breccia is overlain by red deep-sea clay which in turn is covered by a grayish clay.

The physical properties are listed in Table 6 and the plots are presented in Figure 4. The scattering of the GRAPE plots is minor in spite of the lithological variations. An overall increase/decrease of bulk density/porosity occurs in the sediment column with depth. A sudden jump can be observed between the densities of the lower muds and the underlying basalts. Figure 4 also presents slightly lower/higher values for the density/porosity between the gray clayey muds of Cores 15 and 16 and the red deep-sea clays of Core 17.

The data obtained from the syringe method reveal a broader scatter than similar data determined by the GRAPE. This is to be expected when dealing with nonhomogeneous sediments in which the GRAPE data present averaged values per core section, while the syringe values represent point data.

\section{Vane Shear}

Only six vane-shear measurements were made on the cores from this site. In general the shear strength increases in a downward direction (Table 7). The grossly anomalous values are apparently due to inconsistencies in the measuring technique or a weakening of the cores by drilling fluid. Not enough points are present in Figure 5 to draw a realistic enveloping curve. Although a general increase in strength with depth is visible, about $33 \%$ of the points fall completely outside an average curve.

\section{Sites 294 and 295}

These two sites were drilled in the same general area about $1.8 \mathrm{~km}$ apart. Seven cores were recovered from Site 294 from a depth below the sea floor of 0-118 meters. Site 295 was cored between 101 and 158 meters, resulting in 4 cores. The location was in the low-relief undulating topography of the northeastern part of the West Philippine Basin. The entire 100-150 meters of pelagic cover over the acoustic basement consist of brown clay, slightly calcareous near the base, which possibly overlies basalt. The clay is estimated to have an

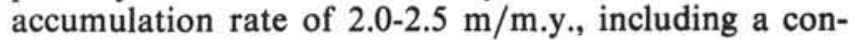
solidation factor.

In most instances the GRAPE data were sufficiently homogeneous to allow averaging for density and porosity. In general, the clayey sediments of Sites $294 / 295$ are of low density and high porosity, reflecting their poor consolidation (Tables 8 and 9; Figure 6). A minor increase/decrease in density/porosity can be observed downhole. However, these trends are flat or even show a minor reversal in Cores 1-3 at Site 295. This may be a 
TABLE 5

Bulk Density, Porosity, and Water Content as Determined by the GRAPE and Syringe Methods, Site292

\begin{tabular}{|c|c|c|c|c|c|c|c|c|c|c|c|}
\hline \multirow[b]{3}{*}{ Core } & \multirow[b]{3}{*}{ Section } & \multirow{3}{*}{$\begin{array}{l}\text { Diameter } \\
\text { (in.) }\end{array}$} & & & \multirow[b]{3}{*}{ Lithology } & \multicolumn{2}{|c|}{ GRAPE } & \multicolumn{3}{|c|}{ Syringe } & \multirow[b]{3}{*}{ Remarks $^{\mathrm{b}}$} \\
\hline & & & \multicolumn{2}{|c|}{ Interval $(\mathrm{cm})$} & & \multirow{2}{*}{$\begin{array}{c}\text { Bulk } \\
\text { Density } \\
(\mathrm{g} / \mathrm{cc})\end{array}$} & \multirow{2}{*}{$\begin{array}{c}\text { Porosity } \\
(\%)\end{array}$} & \multirow{2}{*}{$\begin{array}{c}\text { Water } \\
\text { Content } \\
(\%)\end{array}$} & \multirow{2}{*}{$\begin{array}{l}\text { Bulk } \\
\text { Density } \\
\text { (g/cc) }\end{array}$} & \multirow{2}{*}{$\begin{array}{c}\text { Porosity } \\
(\%)\end{array}$} & \\
\hline & & & GRAPE $^{a}$ & Syringe & & & & & & & \\
\hline 1 & 1 & & & 10 & Nanno ooze & & & 47.12 & 1.51 & 71.3 & \\
\hline & 3 & & & 104 & Clayey-glass ooze & & & 46.99 & 1.53 & 71.7 & \\
\hline \multirow{4}{*}{2} & 4 & 2.6 & A & 110 & Nanno ooze & 1.60 & 68.9 & 43.29 & 1.57 & 68.1 & \\
\hline & 1 & & & 130 & Foram-nanno ooze & & & 42.85 & 1.58 & 67.6 & \\
\hline & 2 & & & $144-150$ & Clayey foram-nanno ooze & & & 46.21 & 1.54 & 71.0 & \\
\hline & 3 & 2.6 & A & 80 & Clayey foram-nanno ooze & 1.75 & 59.0 & 43.36 & 1.34 & 58.1 & \\
\hline \multirow[t]{5}{*}{3} & 2 & 2.6 & $0-75$ & & Clayey micarb & 1.55 & 72.1 & & & & \\
\hline & & 2.6 & $75-150$ & & Clayey micarb & 1.62 & 67.5 & & & & \\
\hline & & 2.6 & 75 & & Volc. ash clayey micarb & 1.96 & 45.2 & & & & Chunk method \\
\hline & 3 & 2.6 & A & & Clayey ooze & 1.67 & 64.3 & & & & \\
\hline & 4 & 2.6 & A & 70 & Clayey ooze & 1.69 & 63.0 & 40.78 & 1.62 & 66.2 & \\
\hline \multirow[t]{5}{*}{4} & 1 & & & 100 & Nanno ooze & & & 41.37 & 1.60 & 66.3 & \\
\hline & 2 & 2.6 & A & & Nanno ooze & 1.66 & 64.9 & & & & \\
\hline & 3 & 2.6 & A & & Nanno ooze & 1.66 & 64.9 & & & & \\
\hline & 4 & 2.6 & A & & Nanno ooze & 1.68 & 63.6 & & & & \\
\hline & 5 & 2.6 & $\mathrm{~A}$ & & Nanno ooze & 1.66 & 64.9 & & & & \\
\hline \multirow[t]{3}{*}{5} & 2 & 2.6 & $0-75$ & & Nanno ooze & 1.68 & 63.6 & & & & \\
\hline & & 2.6 & $75-150$ & 90 & Nanno ooze & 1.73 & 60.3 & 36.69 & 1.66 & 61.0 & \\
\hline & 5 & 2.6 & A & 90 & Nanno ooze & 1.74 & 59.7 & 38.20 & 1.64 & 62.8 & \\
\hline \multirow[t]{3}{*}{6} & 2 & 2.6 & A & 53 & Nanno ooze & 1.70 & 62.3 & 38.37 & 1.65 & 63.5 & \\
\hline & 5 & 2.6 & A & 51 & Nanno ooze & 1.70 & 62.3 & 41.75 & 1.61 & 67.0 & \\
\hline & 6 & & & $0-6$ & Nanno ooze & & & 41.53 & 1.58 & 65.6 & \\
\hline 7 & 2 & 2.6 & A & 80 & Nanno ooze & 1.70 & 62.3 & 36.25 & 1.69 & 61.9 & \\
\hline & 5 & 2.6 & A & 50 & Nanno ooze & 1.70 & 62.3 & 36.61 & 1.64 & 60.2 & \\
\hline 8 & 2 & 2.6 & $0-75$ & & Micarb nanno ooze & 1.71 & 61.6 & & & & \\
\hline & & 2.6 & $75-150$ & & Micarb nanno ooze & 1.92 & 47.9 & & & & \\
\hline & 5 & 2.6 & A & 55 & Micarb nanno ooze & 1.74 & 59.7 & 35.55 & 1.73 & 61.6 & \\
\hline 9 & 2 & 2.6 & A & 83 & Nanno ooze & 1.76 & 58.4 & 36.88 & 1.65 & 60.9 & \\
\hline & 5 & 2.6 & A & 80 & Nanno ooze & 1.79 & 56.4 & 33.42 & 1.73 & 57.7 & \\
\hline 10 & 2 & 2.6 & A & & Nanno ooze & 1.75 & 59.0 & & & & \\
\hline 11 & 2 & 2.6 & A & 75 & Nanno ooze & 1.79 & 56.4 & 32.47 & 1.74 & 56.7 & \\
\hline & 5 & 2.6 & A & $144-150$ & Nanno ooze & 1.78 & 57.0 & 32.75 & 1.77 & 57.9 & \\
\hline 12 & 3 & 2.6 & A & & Foram-nanno ooze & 1.79 & 56.4 & & & & \\
\hline & 4 & 2.6 & $\mathrm{~A}$ & 129 & Foram-nanno ooze & 1.81 & 55.1 & 32.10 & 1.73 & 55.7 & \\
\hline 13 & 2 & 2.6 & $\mathrm{~A}$ & 78 & Foram-nanno ooze & 1.76 & 58.4 & 31.62 & 1.63 & 51.7 & 1) \\
\hline & & & & 90 & Foram-nanno ooze & & & 30.06 & 1.68 & 50.4 & 1) \\
\hline & 5 & 2.6 & A & & Nanno ooze & 1.80 & 55.7 & & & & \\
\hline 14 & 2 & 2.6 & A & & Nanno ooze & 1.65 & 65.6 & & & & \\
\hline & 5 & 2.6 & A & 75 & Nanno ooze & 1.79 & 56.4 & 30.90 & 1.77 & 54.8 & \\
\hline 15 & 3 & 2.6 & $\mathrm{~A}$ & & Nanno ooze & 1.87 & 51.1 & & & & \\
\hline & 4 & 2.6 & A & & Nanno ooze & 1.78 & 57.0 & & & & \\
\hline & 6 & & & 45 & Nanno ooze & & & 33.08 & 1.68 & 55.5 & \\
\hline 16 & 4 & 2.6 & A & & Foram-nanno ooze & 1.62 & 67.5 & & & & \\
\hline & 5 & 2.6 & A & $144-150$ & Foram-nanno ooze & 1.79 & 56.4 & 33.07 & 1.75 & 58.0 & \\
\hline & 6 & & & 136 & Foram-nanno ooze & & & 30.20 & 1.76 & 53.2 & \\
\hline 17 & 5 & 2.6 & A & 65 & Foram-nanno ooze & 1.67 & 64.3 & 36.26 & 1.68 & 60.9 & \\
\hline & 6 & 2.6 & A & 72 & Foram-nanno ooze and ash & 1.85 & 52.5 & 32.67 & 1.73 & 56.7 & \\
\hline
\end{tabular}




\begin{tabular}{|c|c|c|c|c|c|c|c|c|c|c|c|}
\hline \multirow[t]{3}{*}{18} & 5 & 2.6 & A & 68 & Nanno ooze, chalky & 1.79 & 56.4 & 33.77 & 1.74 & 58.8 & \\
\hline & 6 & 2.6 & $0-100$ & 49 & Nanno ooze, chalky & 1.79 & 56.4 & 32.48 & 1.66 & 54.0 & \\
\hline & & 2.6 & $100-150$ & & Nanno ooze, chalky & 1.74 & 59.7 & & & & \\
\hline \multirow[t]{2}{*}{19} & 2 & 2.6 & A & 75 & Nanno ooze, chalky & 1.79 & 56.4 & 30.64 & 1.80 & 55.1 & \\
\hline & 5 & 2.6 & A & 49 & Nanno ooze, chalky & 1.80 & 55.7 & 32.52 & 1.66 & 54.1 & \\
\hline \multirow[t]{2}{*}{20} & 2 & 2.6 & $0-75$ & & Nanno ooze, chalky & 1.72 & 61.0 & & & & \\
\hline & & 2.6 & $75-100$ & 80 & Nanno ooze, chalky & 1.80 & 55.7 & 30.73 & 1.76 & 54.1 & \\
\hline \multirow[t]{3}{*}{21} & 4 & & & $144-150$ & Nanno ooze, chalky & & & 33.03 & 1.99 & 65.8 & \\
\hline & 5 & 2.6 & A & 122 & Nanno ooze, chalky & 1.71 & 61.6 & 32.12 & 1.65 & 53.2 & Chunk method \\
\hline & & 2.6 & $75-80$ & & Nanno ooze, chalky & 1.78 & 57.0 & & & & \\
\hline \multirow[t]{2}{*}{22} & 3 & 2.6 & $0-50$ & & Ash nanno ooze & 1.67 & 64.3 & & & & \\
\hline & & 2.6 & $50-150$ & 106 & Ash nanno ooze & 1.71 & 61.6 & 31.07 & 1.64 & 50.9 & Chunk method \\
\hline \multirow[t]{2}{*}{23} & 3 & 2.6 & A & & Chalky nanno ooze & 1.80 & 55.7 & & & & \\
\hline & 4 & 2.6 & A & 74 & Chalky nanno ooze & 1.85 & 52.5 & 31.38 & 1.76 & 55.2 & \\
\hline \multirow[t]{2}{*}{24} & 2 & 2.6 & A & & Chalky nanno ooze & 1.76 & 58.4 & & & & \\
\hline & 3 & 2.6 & A & 78 & Chalky nanno ooze & 1.80 & 55.7 & 31.40 & 1.69 & 52.9 & Chunk method \\
\hline 25 & 1 & & & 111 & Chalky nanno ooze & & & 30.66 & 1.66 & 50.9 & Chunk method \\
\hline \multirow[t]{2}{*}{26} & 1 & & & $144-150$ & Nanno chalk & & & 28.85 & 1.77 & 51.1 & Chunk method \\
\hline & 2 & & & 107 & Nanno chalk & & & 29.28 & 1.78 & 52.0 & Chunk method \\
\hline 27 & 1 & & & 87 & Nanno chalk & & & 27.58 & 1.76 & 48.7 & Chunk method \\
\hline 29 & 1 & & & 104 & Nanno chalk & & & 29.31 & 1.71 & 50.2 & Chunk method \\
\hline \multirow[t]{3}{*}{30} & 1 & 2.4 & $0-50$ & & Nanno chalk & 1.84 & 53.1 & & & & \\
\hline & & 2.15 & $50-100$ & & Nanno chalk & 2.02 & 41.3 & & & & \\
\hline & & 2.2 & $100-150$ & 102 & Nanno chalk & 1.97 & 44.6 & 29.52 & 1.69 & 49.8 & Chunk method \\
\hline 31 & 2 & 2.33 & A & $144-150$ & Nanno chalk & 1.86 & 51.8 & 28.64 & 1.80 & 51.5 & Chunk method \\
\hline 32 & 1 & 2.42 & A & & Nanno chalk & 1.89 & 49.8 & & & & \\
\hline \multirow{3}{*}{33} & 1 & & & 26 & Nanno chalk & & & 22.77 & 1.55 & 35.4 & Chunk method \\
\hline & 2 & 1.82 & A & & Nanno chalk & 2.13 & 34.1 & & & & \\
\hline & & 2.32 & A & & Nanno chalk & 2.19 & 30.2 & & & & \\
\hline 34 & 1 & 2.6 & A & 96 & Nanno chalk & 1.76 & 58.4 & 25.04 & & & Chunk method \\
\hline 35 & 2 & 2.38 & A & 20 & Nanno chalk & 2.16 & 32.1 & 18.67 & & & Chunk method \\
\hline \multirow{3}{*}{36} & 1 & 2.2 & A & & Nanno chalk & 2.13 & 34.1 & & & & \\
\hline & 3 & 2.2 & A & $142-150$ & Nanno chalk & 1.89 & 49.8 & 32.48 & 1.70 & 55.1 & Chunk method \\
\hline & 5 & 2.3 & A & & Rad-nanno chalk & 2.16 & 32.1 & & & & \\
\hline \multirow[t]{2}{*}{37} & 2 & & & 122 & Nanno chalk & & & 28.06 & 1.82 & 51.0 & Chunk method \\
\hline & 3 & 2.6 & A & & Ash nanno chalk & 1.85 & 52.5 & & & & \\
\hline \multirow[t]{2}{*}{38} & 2 & 2.6 & $0-75$ & 54 & Nanno micarb chalk & 1.75 & 59.0 & 27.22 & 1.82 & 49.5 & Chunk method \\
\hline & & 2.6 & $75-100$ & & Nanno micarb chalk and ash & 1.79 & 56.4 & & & & \\
\hline 39 & 3 & 2.3 & A & 50 & Foram micarb nanno chalk & 2.25 & 26.2 & 17.35 & 1.99 & 34.5 & Chunk method \\
\hline 40 & 1 & 2.34 & A & & Basalt & 2.68 & & & & & \\
\hline 42 & 3 & 2.34 & $75-150$ & & Basalt & 2.68 & & & & & \\
\hline 44 & 5 & 2.35 & A & & Basalt & 2.69 & & & & & \\
\hline 46 & 2 & 2.30 & A & & Basalt & 2.76 & & & & & \\
\hline 47 & 2 & 2.35 & A & & Basalt & 2.72 & & & & & \\
\hline
\end{tabular}

${ }^{\mathrm{a}} \mathrm{A}=$ average reading from the GRAPE analog record.

$\left.b_{1}\right)=$ end of syringe was not covered properly, end of sample may have lost some water. 


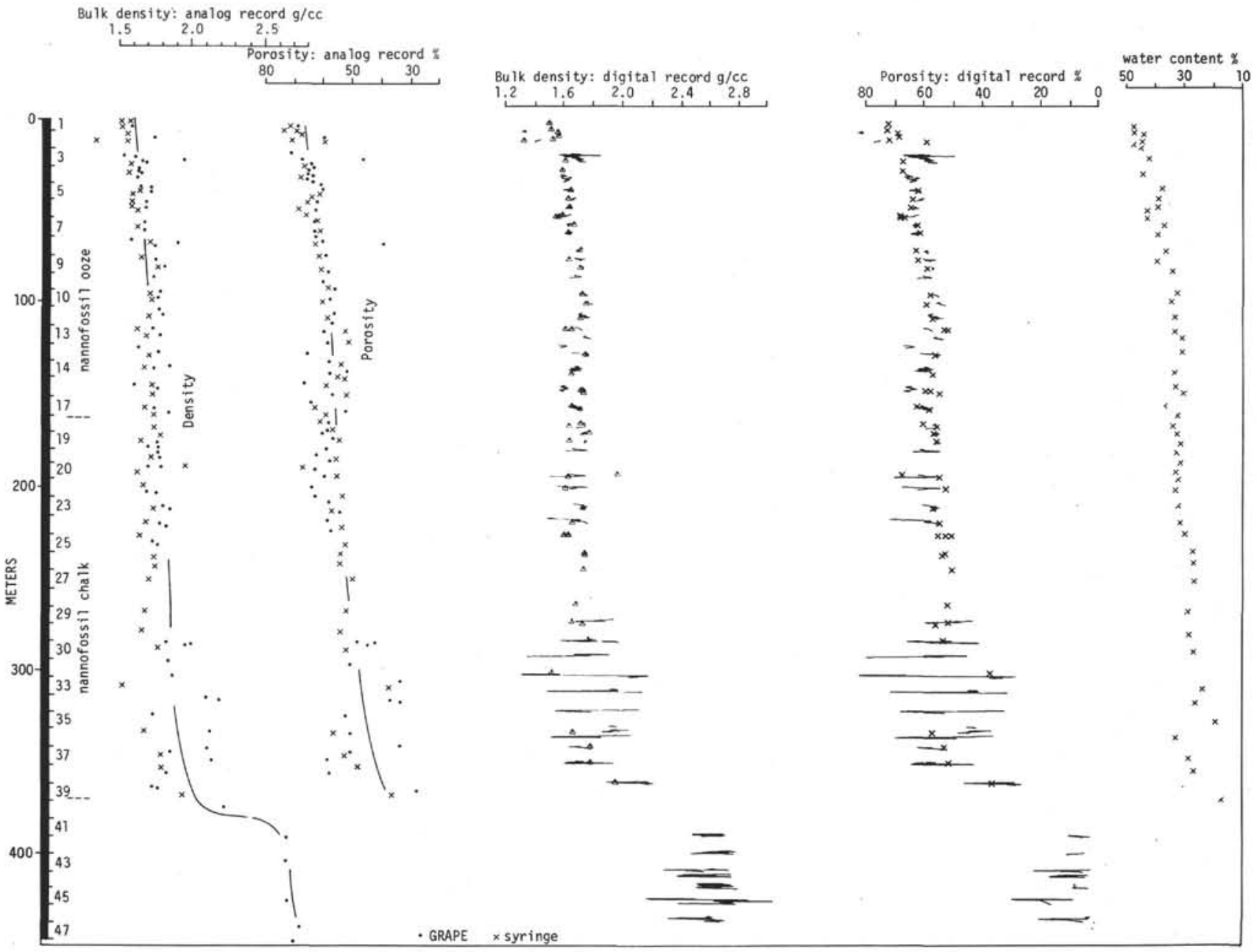

Figure 3. Plot of physical properties for Site 292. GRAPE analog record readings as well as computer plot are presented in addition to laboratory analyses (syringe and chunk methods). On the left the cores are given as black rectangles and the general lithology.

result of the greater drilling disturbances observed in the cores from Site 295 compared to Site 294.

The syringe data for density and porosity correlate closely with the GRAPE analog readings. The water content plot reveals more scattering and a general decrease downhole with a possible exception for the values from Site 295.

\section{Vane Shear}

The vane-shear data for Site 294 (Figure 7, Table 10) show the least variation for a given depth of any sequence cored during Leg 31. This result is due in part to the homogeneous lithology as well as minor remolding during coring. The enveloping curve is unusual in that it shows a concave upward shape.

In the same figure the data for Site 295 are presented (see Table 11). The scatter in these data is also thought to be the result of more intense drilling disturbance. As a result the data from Site 294 are considered to be more valuable and more indicative for the shear strength in this brown clay.

\section{Site 296}

Site 296 was primarily intended as a biostratigraphic hole. Located at the northern end of the Palau-Kyushu Ridge, the site had to be at a depth substantially shallower than the calcium carbonate compensation depth, far enough north to produce a midlatitude flora and fauna, and beneath sufficiently productive waters.

A total of 65 cores were retrieved over a depth range of $0-1087$ meters below the sea floor. The upper 48 cores (depth $0-453 \mathrm{~m}$ ) consist of Pleistocene to late Oligocene nannofossil oozes and chalks with varieties including clay, forams, radiolarians, or ash-bearing/rich and volcanic ash beds. In general, the volcanic activity decreased from late Oligocene to the Holocene, being replaced by a pelagic nannofossil sedimentation.

Radiolarians are present in the upper portions of the cored interval. They become absent with increasing depth and reappear again in Cores 22-38. Foraminifera are also variable in their content but occur down to Core 56. 
TABLE 6

Bulk Density, Porosity, and Water Content as Determined by the GRAPE and Syringe Methods, Site 293

\begin{tabular}{|c|c|c|c|c|c|c|c|c|c|c|c|}
\hline \multirow[b]{3}{*}{ Core } & \multirow[b]{3}{*}{ Section } & \multirow{3}{*}{$\begin{array}{l}\text { Diameter } \\
\text { (in.) }\end{array}$} & & & \multirow[b]{3}{*}{ Lithology } & \multicolumn{2}{|c|}{ GRAPE } & \multicolumn{3}{|c|}{ Syringe } & \multirow[b]{3}{*}{ Remarks } \\
\hline & & & \multicolumn{2}{|c|}{ Interval $(\mathrm{cm})$} & & \multirow{2}{*}{$\begin{array}{c}\text { Bulk } \\
\text { Density } \\
(\mathrm{g} / \mathrm{cc})\end{array}$} & \multirow{2}{*}{$\begin{array}{l}\text { Porosity } \\
(\%)\end{array}$} & \multirow{2}{*}{$\begin{array}{c}\text { Water } \\
\text { Content } \\
(\%)\end{array}$} & \multirow{2}{*}{$\begin{array}{l}\text { Bulk } \\
\text { Density } \\
\text { (g/cc) }\end{array}$} & \multirow{2}{*}{$\begin{array}{l}\text { Porosity } \\
\text { (\%) }\end{array}$} & \\
\hline & & & GRAPE $^{\mathrm{a}}$ & Syringe & & & & & & & \\
\hline \multirow[t]{3}{*}{2} & 4 & & & $144-150$ & Sandy clay & & & 42.70 & 1.51 & 64.4 & \\
\hline & & & & $144-150$ & Sandy clay & & & 32.31 & 1.71 & 55.2 & \\
\hline & 5 & 2.6 & A & 75 & Sand, silt, clay & 1.79 & 56.4 & 42.60 & 1.57 & 66.7 & \\
\hline \multirow[t]{2}{*}{3} & 3 & 2.6 & A & & Sandy silt & 1.50 & 75.4 & & & & \\
\hline & 5 & 2.6 & A & 100 & Clayey silt, silt & 1.68 & 63.6 & 33.73 & 1.70 & 57.3 & \\
\hline \multirow[t]{2}{*}{4} & 1 & & & $144-150$ & Clayey silt & & & 35.31 & 1.69 & 59.8 & \\
\hline & 2 & 2.6 & A & 45 & Clayey silt & 1.68 & 63.6 & 36.59 & 1.68 & 61.6 & \\
\hline 5 & 4 & 2.6 & A & 60 & Clayey silt, silt, sand & 1.65 & 65.6 & 33.94 & 1.61 & 54.6 & \\
\hline 6 & 2 & & & 102 & Clayey silt & & & 36.38 & 1.65 & 60.2 & \\
\hline \multirow[t]{3}{*}{7} & 1 & 2.6 & A & & Clayey silt & 1.65 & 65.6 & & & & \\
\hline & 2 & & & $144-150$ & Clayey silt & & & 39.12 & 1.60 & 62.7 & \\
\hline & 6 & 2.6 & A & & Clayey silt & 1.65 & 65.6 & & & & \\
\hline 8 & 1 & & & $144-150$ & Clayey silt & & & 30.11 & 1.74 & 52.5 & \\
\hline \multirow{2}{*}{9} & 2 & 2.6 & A & 10 & Clay & 1.65 & 65.6 & 34.20 & 1.63 & 55.9 & \\
\hline & 6 & 2.6 & A & & Clayey silt, silt & 1.76 & 58.4 & & & & \\
\hline \multirow[t]{3}{*}{10} & 2 & & & $144-150$ & Clayey silt & & & 33.60 & 1.66 & 55.9 & \\
\hline & & & & $144-150$ & Clayey silt & & & 34.32 & 1.70 & 58.3 & \\
\hline & 3 & 2.6 & A & & Clayey silt & 1.74 & 59.7 & & & & \\
\hline \multirow[t]{2}{*}{12} & 2 & 2.6 & A & & Clayey silt & 1.87 & 51.1 & & & & \\
\hline & 3 & 2.6 & A & & Clayey silt & 1.83 & 53.8 & & & & \\
\hline \multirow[t]{3}{*}{13} & 1 & & & $144-150$ & Clayey silt & & & 32.04 & 1.76 & 56.4 & \\
\hline & & & & $144-150$ & Clayey silt & & & 17.21 & 2.06 & 35.4 & \\
\hline & 2 & 2.6 & A & & Clayey silt & 1.75 & 59.0 & & & & \\
\hline \multirow[t]{3}{*}{15} & 1 & & & 130 & Clayey silt and clay & & & 29.64 & & & \\
\hline & 3 & & & $144-150$ & Clayey silt & & & 25.20 & 1.86 & 46.8 & \\
\hline & 4 & 2.6 & A & 130 & Clayey silt & 1.86 & 51.8 & 29.91 & 1.73 & 51.7 & \\
\hline 16 & 5 & 2.6 & A & 8 & Clay & 1.84 & 53.1 & 30.91 & 1.72 & 53.2 & \\
\hline 17 & 4 & & & $144-150$ & Clay & & & 36.42 & 1.67 & 60.8 & \\
\hline & 5 & 2.6 & A & & Clay & 1.76 & 58.4 & & & & \\
\hline 18 & 1 & 2.6 & $0-100$ & & Clay & 1.86 & & & & & \\
\hline & & 2.32 & $100-150$ & & Basalt & 2.62 & & & & & \\
\hline 20 & 1 & 2.2 & A & & Basaltic breccia & 2.58 & & & & & \\
\hline & & & Piece no. & & & & & & & & \\
\hline & & 2.15 & 2 & & Basaltic breccia & 2.64 & & & & & Count method \\
\hline & & 2.12 & 5 & & Basaltic breccia & 2.61 & & & & & Count method \\
\hline & & 2.09 & 7 & & Basaltic breccia & 2.65 & & & & & Count method \\
\hline & & 2.1 & 16 & & Basaltic breccia & 2.50 & & & & & Count method \\
\hline & & 2.2 & 18 & & Basaltic breccia & 2.60 & & & & & Count method \\
\hline 21 & 2 & 2.32 & A & & Basaltic breccia & 2.62 & & & & & \\
\hline
\end{tabular}

${ }^{\mathrm{a}} \mathrm{A}=$ average reading from the GRAPE analog record.

From 453-1087 meters a mixture of tuffs, lapilli tuffs, volcanic sandstones, and siltstones and occasional ashrich/bearing nannofossil chalks were encountered. This lower section especially illustrates a continued building up by accumulation of volcanic debris with accompanying subsidence of the Palau-Kyushu Ridge. Sedimentation breaks occur in the Miocene section (Cores 23-35).

The bulk density, porosity, and water content data, as presented in Table 12 and Figure 8, reveal that the density values obtained by the syringe method are almost always lower than the GRAPE analog readings. Although the position of the syringe is arbitrarily picked, it presents a point data and is too small in volume for accuracy. Figure 8 shows that, with a few exceptions, the scattering is low and that only a minor change with depth occurs. No significant difference can be seen between the nannofossil ooze, nannofossil chalk, and the ash-rich/bearing nannofossil chalk. Water content data reveal the same overall trend.

\section{Vane Shear}

The vane-shear measurements (Figure 9, Table 13) increase rapidly along a well-defined trend to 50 meters. At greater depths the data show more scattering and the rate of strengthening decreases. The variation in shear strength from 50 to 155 meters is in part due to drilling deformation, but also may be a function of periodic variation in natural consolidation-lithification factors at depths greater than 100 meters.

\section{Site 297}

This site was located on the outer swell of the Nankai Trough with a sediment cover typical of the western Shikoku Basin. In total, 27 cores were collected representing 679.5 meters of sediment. The upper 54 meters are characterized by a diatom/ash-rich clay that changes into a clay-rich nannofossil ooze for the next 36 meters, followed by 240 meters of clayey siltstone. This material becomes a silty claystone with interbedded 


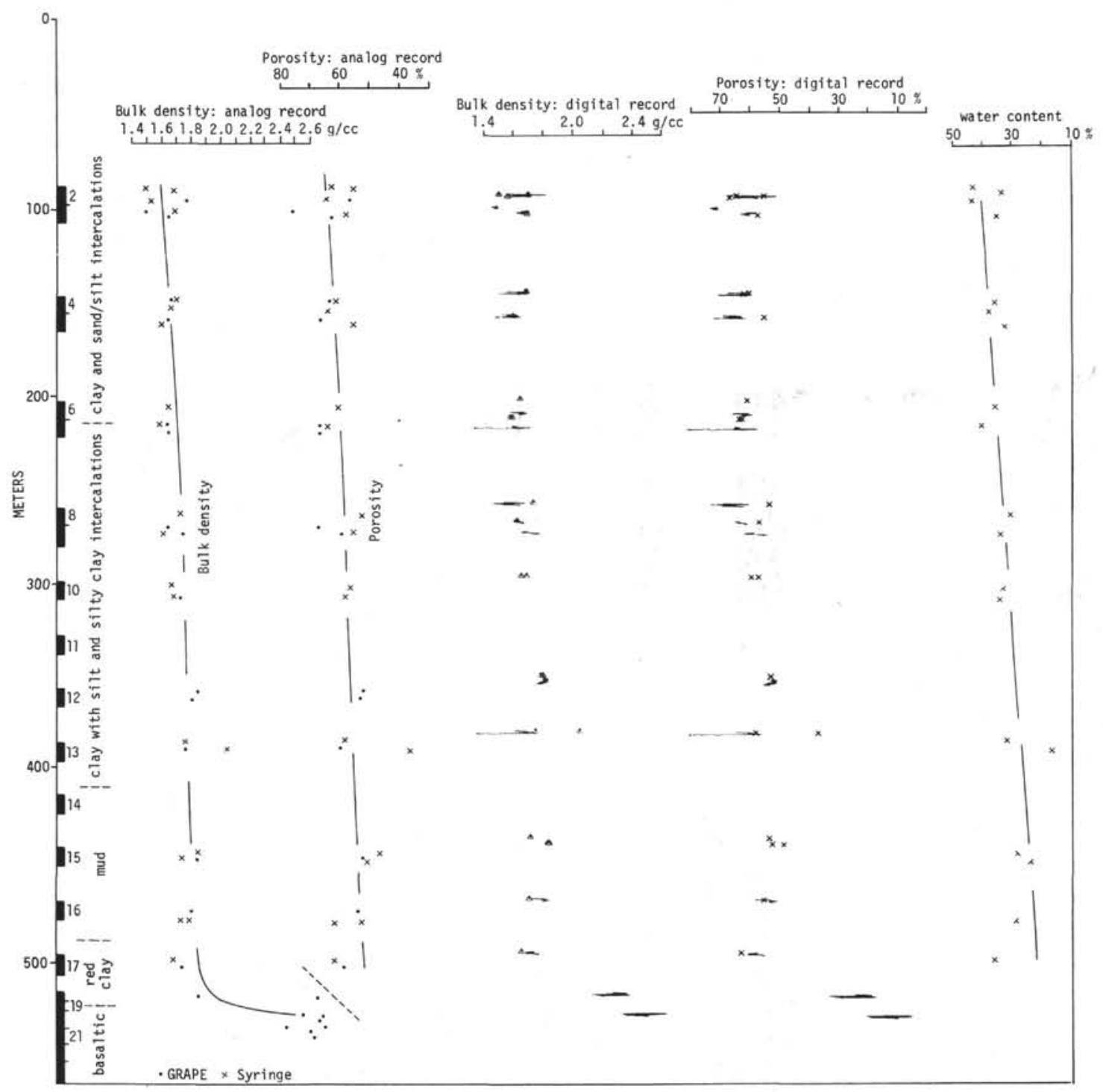

Figure 4. Plot of physical properties for Site 293. GRAPE analog record readings as well as computer plot are presented in addition to laboratory analyses (syringe and chunk methods). On the left the cores are given as black rectangles and the general lithology.

TABLE 7

Vane Shear Data, Site 293

\begin{tabular}{cclc}
\hline $\begin{array}{c}\text { Sample } \\
\text { (Interval in cm) }\end{array}$ & $\begin{array}{c}\text { Depth } \\
\text { (to nearest } \\
\text { half meter) }\end{array}$ & $\begin{array}{c}\text { Plane of } \\
\text { Measurement }\end{array}$ & $\begin{array}{c}\text { Shear } \\
\text { Strength } \\
\text { (mbars) }\end{array}$ \\
\hline $2-5,80$ & 96.5 & Vertical & 195.3 \\
$3-5,100$ & 106.0 & Vertical & 527.3 \\
$4-2,150$ & 158.0 & Horizontal & 332.0 \\
$5-4,150$ & 161.5 & Horizontal & 214.8 \\
$6-2,150$ & 205.5 & Horizontal & 507.8 \\
$12-0,0$ & 354.5 & Vertical & 703.1 \\
\hline
\end{tabular}

graded silt and sand in Cores 14-22 representing the 330570 meter depth. This is underlain by a fine vitric ash and ash-rich claystone.

Most core sections revealed a rather straight analog GRAPE curve, and the average could be used to determine the bulk density. Some sections gave very irregular curves making it difficult to select the most representative value. The laboratory analyses may not have been as accurate as on previous sites due to rougher seas. This induced rolling and additional vibration may account for the anomalously high laboratory density measurements relative to the GRAPE values.

The results are given in tabulated form in Table 14 and graphically in Figure 10. Although the average gives the normal increase/decrease in density/porosity-water content, a number of zones fall too far outside the mean- 


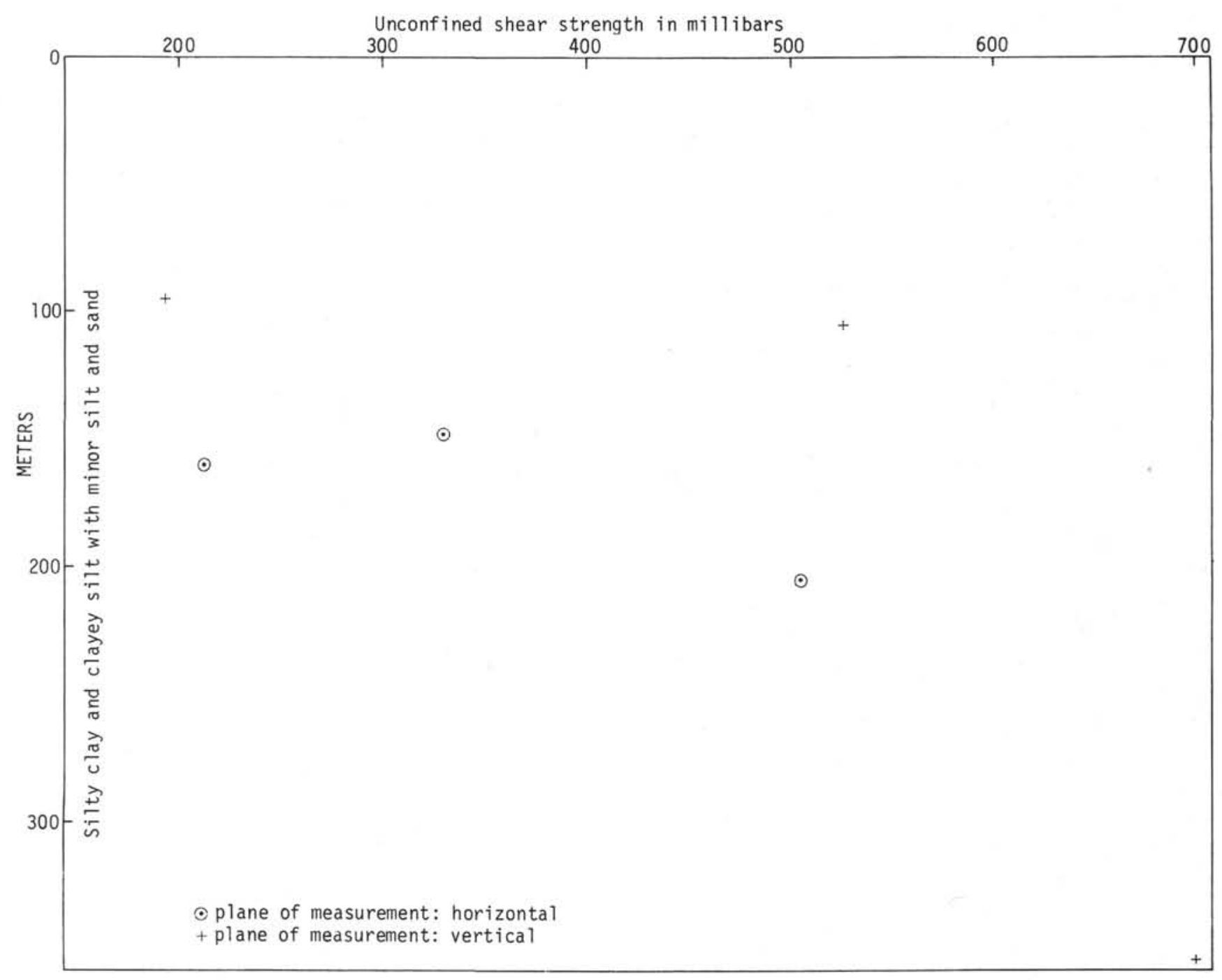

Figure 5. Plot of unconfined shear strength with depth, Site 293.

line to be considered as scattering. Figure 10 shows that all data points fall left of the mean for Cores 9-13, after which a sudden jump to the right occurs. Except for one density analog reading in Core 20 , this right-side position continues down to Core 24 . A change in lithology from clay to a sandy-silty clay probably accounts for this. Part of the scattering in this lithological unit results from the layering of graded silts and sand in the claystone. This is not visible in the water-content column due to less data points based on samples that were collected in claystone only.

A sudden change is seen when entering the lowest unit. Within this unit a downward increase in clay was observed which influences the values of the physical properties.

\section{Vane Shear}

The diatom-ash nannofossil-rich silty clays cored at this site comprise a typical hemipelagic sediment. The shear strength of these deposits (Figure 11, Table 15) increases approximately linearly to 125 meters. At greater depths the enveloping curve steepens and reflects a concave downward shape.

\section{Site 298}

In total, 611 meters were drilled with a recovery of 16 cores. Site 298 was located on the lowermost inner trench wall of the western Nankai Trough. This feature is thought to represent a recently rejuvenated deep-sea trench and a line of subduction. The prime objective at this site was to obtain a representative sample of deformed trench fill.

The upper four cores recovered predominantly a silty clay and clayey silt with varying amounts of sand and minor quantities of calcareous sandstone and limestone. Underneath this lithological unit the influence of the subduction could be observed by the shaly character of the sediment. The lithologies varied between fissile claystone, silty claystone, siltstone, and clayey and silty sands. The overconsolidation of the clay was remarkable (Trabant et al., this volume). In contrast with the fissile claystone and silty claystones, the sand 
TABLE 8

Bulk Density, Porosity, and Water Content as Determined by the GRAPE and Syringe Methods, Site 294

\begin{tabular}{|c|c|c|c|c|c|c|c|c|c|c|c|}
\hline \multirow[b]{3}{*}{ Core } & \multirow[b]{3}{*}{ Section } & \multirow{3}{*}{$\begin{array}{l}\text { Diameter } \\
\text { (in.) }\end{array}$} & \multirow{2}{*}{\multicolumn{2}{|c|}{ Interval $(\mathrm{cm})$}} & \multirow[b]{3}{*}{ Lithology } & \multicolumn{2}{|c|}{ GRAPE } & \multicolumn{3}{|c|}{ Syringe } & \multirow[b]{3}{*}{ Remarks } \\
\hline & & & & & & \multirow{2}{*}{$\begin{array}{c}\text { Bulk } \\
\text { Density } \\
(\mathrm{g} / \mathrm{cc})\end{array}$} & \multirow{2}{*}{$\begin{array}{c}\text { Porosity } \\
(\%)\end{array}$} & \multirow{2}{*}{$\begin{array}{c}\text { Water } \\
\text { Content } \\
(\%)\end{array}$} & \multirow{2}{*}{$\begin{array}{c}\text { Bulk } \\
\text { Density } \\
(\mathrm{g} / \mathrm{cc})\end{array}$} & \multirow{2}{*}{$\begin{array}{c}\text { Porosity } \\
(\%)\end{array}$} & \\
\hline & & & GRAPE $^{\mathrm{a}}$ & Syringe & & & & & & & \\
\hline 1 & 3 & 2.6 & A & & Silt-rich clay & 1.14 & 99.0 & & & & \\
\hline & 4 & 2.6 & A & 75 & Silt-rich clay & 1.20 & 95.1 & 57.22 & 1.37 & 78.2 & \\
\hline \multirow[t]{3}{*}{2} & 1 & & & $144-150$ & Clay & & & 71.31 & 1.25 & 89.1 & \\
\hline & & & & $144-150$ & Clay & & & 72.46 & 1.20 & 87.1 & \\
\hline & 2 & 2.6 & A & 90 & Clay & 1.23 & 93.1 & 67.36 & 1.30 & 87.3 & \\
\hline \multirow[t]{4}{*}{3} & 2 & 2.6 & A & & Clay & 1.27 & 90.5 & & & & \\
\hline & 4 & & & $144-150$ & Clay & & & 62.03 & 1.33 & 82.2 & \\
\hline & 5 & 2.6 & A & 40 & Clay & 1.26 & 91.1 & 40.06 & 1.57 & 78.8 & \\
\hline & & & & 90 & Clay & & & 65.77 & 1.26 & 83.1 & \\
\hline \multirow[t]{3}{*}{4} & 3 & 2.6 & A & & Clay & 1.33 & 86.6 & & & & \\
\hline & 5 & 2.6 & $0-100$ & & Clay & 1.57 & 70.8 & & & & Irregular \\
\hline & & 2.6 & $100-150$ & $144-150$ & Clay & 1.40 & 82.0 & 50.54 & 1.56 & 78.7 & \\
\hline \multirow[t]{2}{*}{6} & 1 & 2.6 & $0-75$ & & Clay & 1.40 & 82.0 & & & & \\
\hline & & 2.6 & $75-150$ & 60 & Clay and volc. ash & 1.63 & 66.9 & 59.94 & 1.35 & 80.7 & Average of peaks \\
\hline
\end{tabular}

${ }_{\mathrm{A}}^{\mathrm{A}}=$ average reading from the GRAPE analog record. Irregular $=$ irregular analog record.

TABLE 9

Bulk Density, Porosity, and Water Content as Determined by the GRAPE and Syringe Methods, Site 295

\begin{tabular}{|c|c|c|c|c|c|c|c|c|c|c|c|}
\hline \multirow[b]{3}{*}{ Core } & \multirow[b]{3}{*}{ Section } & \multirow{3}{*}{$\begin{array}{l}\text { Diameter } \\
\text { (in.) }\end{array}$} & & & \multirow[b]{3}{*}{ Lithology } & \multicolumn{2}{|c|}{ GRAPE } & \multicolumn{3}{|c|}{ Syringe } & \multirow[b]{3}{*}{ Remarks } \\
\hline & & & \multicolumn{2}{|c|}{ Interval $(\mathrm{cm})$} & & \multirow{2}{*}{$\begin{array}{c}\text { Bulk } \\
\text { Density } \\
(\mathrm{g} / \mathrm{cc})\end{array}$} & \multirow{2}{*}{$\begin{array}{c}\text { Porosity } \\
(\%)\end{array}$} & \multirow{2}{*}{$\begin{array}{c}\text { Water } \\
\text { Content } \\
(\%)\end{array}$} & \multirow{2}{*}{$\begin{array}{c}\text { Bulk } \\
\text { Density } \\
(\mathrm{g} / \mathrm{cc})\end{array}$} & \multirow{2}{*}{$\begin{array}{c}\text { Porosity } \\
(\%)\end{array}$} & \\
\hline & & & GRAPE $^{a}$ & Syringe & & & & & & & \\
\hline \multirow[t]{2}{*}{1} & 3 & 2.6 & A & 30 & Clay and volc. ash & 1.44 & 79.3 & 53.36 & 1.42 & 75.7 & \\
\hline & 4 & 2.6 & A & $143-150$ & Clay and volc. ash & 1.45 & 78.7 & 50.82 & 1.49 & 75.6 & \\
\hline \multirow[t]{2}{*}{2} & 2 & 2.6 & A & 40 & Clay and volc. ash & 1.35 & 85.2 & 55.38 & 1.40 & 77.5 & \\
\hline & 5 & & & $144-150$ & Clay and volc. ash & & & 59.05 & 1.36 & 80.3 & \\
\hline \multirow{3}{*}{3} & 3 & 2.6 & $\mathrm{~A}$ & 40 & Clay & 1.34 & 85.9 & 61.64 & 1.36 & 83.6 & \\
\hline & & & & $144-150$ & Clay & & & 59.00 & 1.37 & 80.9 & \\
\hline & 4 & 2.6 & A & 40 & Clay & 1.37 & 83.9 & 58.11 & 1.40 & 81.4 & \\
\hline
\end{tabular}

${ }^{\mathrm{a}} \mathrm{A}=$ average reading from the GRAPE analog record.

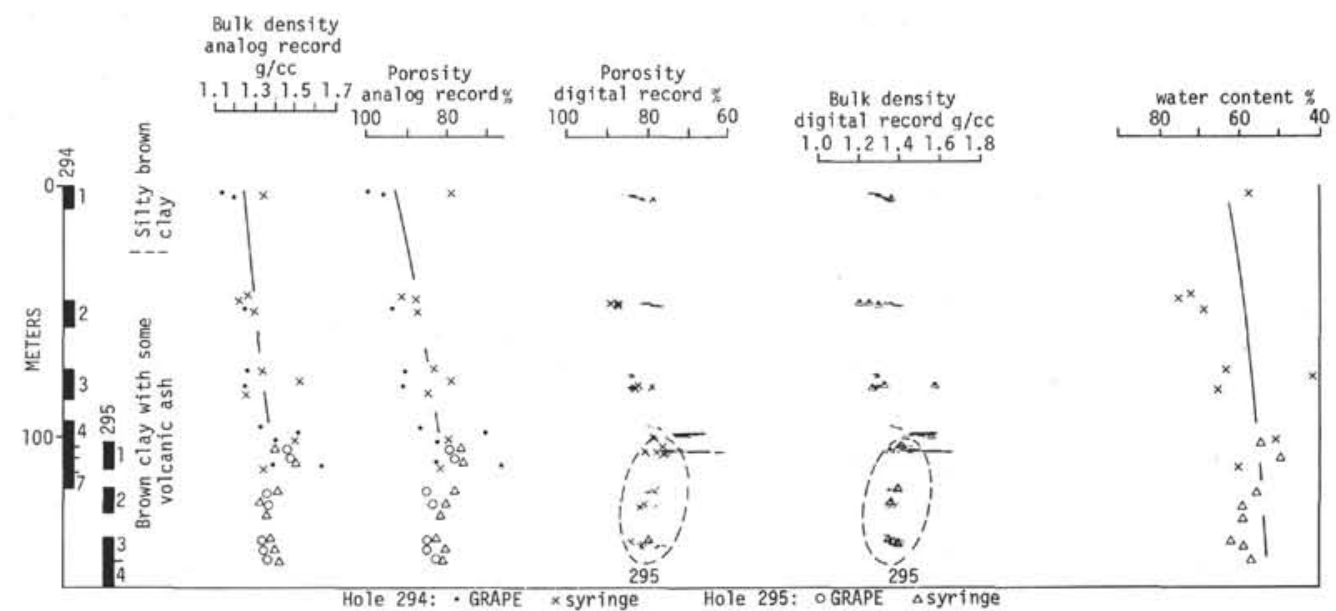

Figure 6. Plot of physical properties for Sites 294 and 295. GRAPE analog record readings as well as computer plot are presented in addition to laboratory analyses (syringe and chunk methods). On the left the cores are given as black rectangles and the general lithology. 


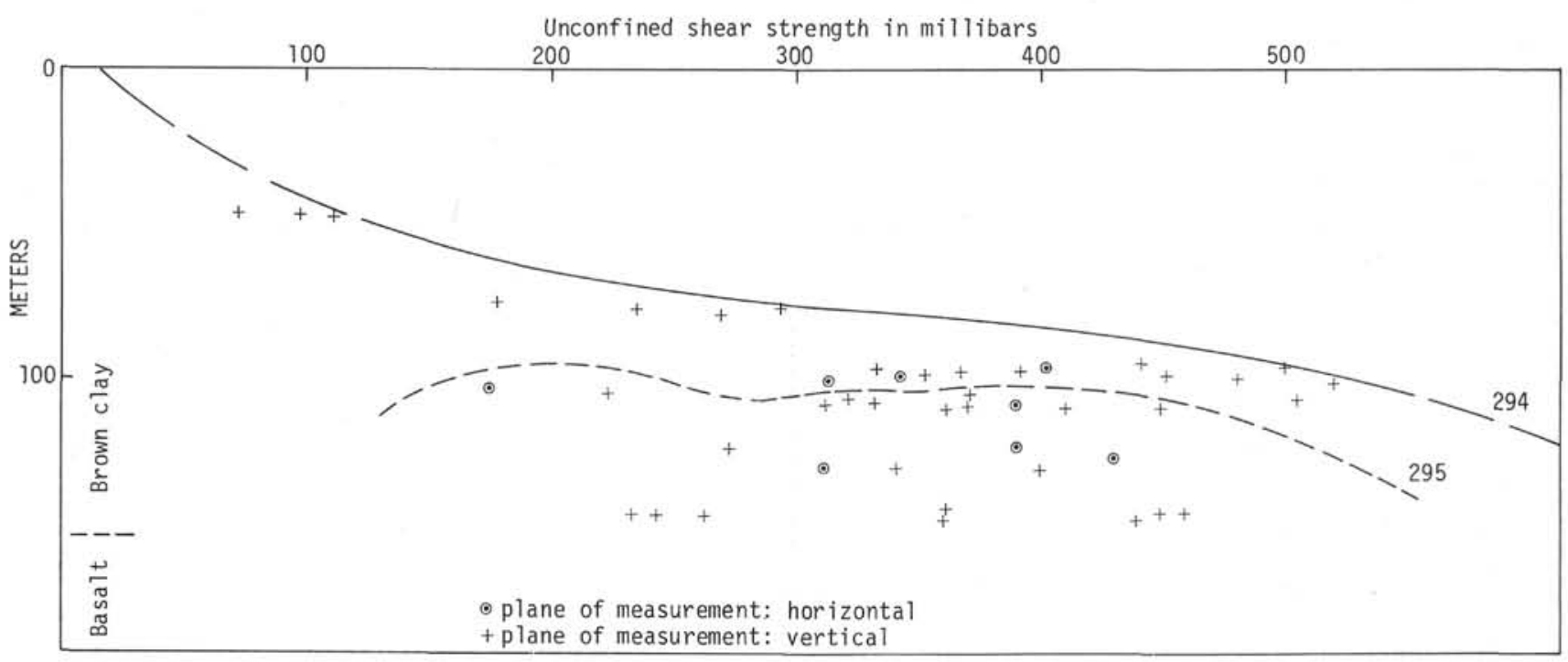

Figure 7. Plot of unconfined shear strength with depth, Sites 294 and 295. The dashed line separates the data from both sites.

TABLE 10

Vane Shear Data, Site 294

\begin{tabular}{cclc}
\hline $\begin{array}{c}\text { Sample } \\
\text { (Interval in cm) }\end{array}$ & $\begin{array}{c}\text { Depth } \\
\text { (to nearest } \\
\text { half meter) }\end{array}$ & $\begin{array}{c}\text { Plane of } \\
\text { Measurement }\end{array}$ & $\begin{array}{c}\text { Shear } \\
\text { Strength } \\
\text { (mbar) }\end{array}$ \\
\hline $2-1,136$ & 53 & Vertical & 72.2 \\
$2-2,35$ & 54 & Vertical & 97.6 \\
$2-2,120$ & 55 & Vertical & 111.3 \\
$3-1,140$ & 77 & Vertical & 177.6 \\
$3-2,110$ & 79 & Vertical & 292.8 \\
$3-3,40$ & 79 & Vertical & 234.2 \\
$3-4.90$ & 81 & Vertical & 268.4 \\
$4-1,135$ & 94 & Vertical & 439.2 \\
$4-2,100$ & 96 & Vertical & 497.8 \\
$4-2,150$ & 96.5 & Horizontal & 400.2 \\
$4-3,32$ & 97 & Vertical & 331.8 \\
$4-3,134$ & 98 & Vertical & 366.0 \\
$4-4,7$ & 98 & Vertical & 390.4 \\
$4-4,60$ & 99 & Vertical & 351.4 \\
$4-4,129$ & 99.5 & Vertical & 449.0 \\
$4-4,150$ & 99.5 & Horizontal & 341.6 \\
$4-5,45$ & 100 & Vertical & 478.3 \\
$4-6,0$ & 101 & Horizontal & 312.32 \\
$4-6,45$ & 101 & Vertical & 517.3 \\
$6-1,71$ & 114 & Vertical & 502.6 \\
\hline
\end{tabular}

beds remain unconsolidated/unlithified throughout this lithological unit. Sand and silt beds, ranging in thickness up to $16 \mathrm{~cm}$, occurred in 8 out of the 12 cores of this unit. Some were graded, others did not show such structure. Overturning of some beds could be established.

The analog records were very erratic due to the fissile nature of the material, and proper estimation of the density values may be slightly off. Many section curves were broken up into portions (Table 16) to provide better averages. When the record from a section was divided into two or three portions, a considerable difference in density resulted. Normally the middle portion had a much higher value than the top and bottom ones. This is thought to be due to fissility, creating more hair cracks the longer the material moves up during coring. In addi-
TABLE 11

Vane Shear Data, Site 295

\begin{tabular}{llll}
\hline $\begin{array}{c}\text { Sample } \\
\text { (Interval in cm) }\end{array}$ & $\begin{array}{c}\text { Depth } \\
\text { (to nearest } \\
\text { half meter) }\end{array}$ & $\begin{array}{c}\text { Plane of } \\
\text { Measurement }\end{array}$ & $\begin{array}{c}\text { Shear } \\
\text { Strength } \\
\text { (mbar) }\end{array}$ \\
\hline $1-2,0$ & 104.5 & Horizontal & 175.7 \\
$1-2,140$ & 106 & Vertical & 370.9 \\
$1-3,25$ & 106 & Vertical & 224.5 \\
$1-3,134$ & 107.5 & Vertical & 322.1 \\
$1-4,25$ & 108 & Vertical & 390.4 \\
$1-4,90$ & 108.5 & Vertical & 331.8 \\
$1-4,140$ & 109 & Vertical & 370.9 \\
$1-5,0$ & 109 & Horizontal & 390.4 \\
$1-5,50$ & 109.5 & Vertical & 312.3 \\
$1-5,98$ & 110 & Vertical & 409.9 \\
$1-5,100$ & 110 & Vertical & 449.0 \\
$1-5,140$ & 110.5 & Vertical & 361.1 \\
$1-5,150$ & 110.5 & Vertical & 390.4 \\
$2-2,0$ & 122.0 & Horizontal & 390.4 \\
$2-2,59$ & 122.5 & Vertical & 273.3 \\
$2-4,0$ & 125.0 & Horizontal & 429.4 \\
$2-6,0$ & 128.0 & Horizontal & 312.3 \\
$2-6,34$ & 128.0 & Vertical & 341.6 \\
$2-6,125$ & 129 & Vertical & 400.2 \\
$3-2,38$ & 154 & Vertical & 361.1 \\
$3-2,111$ & 154.5 & Vertical & 449.0 \\
$3-3,45$ & 155.5 & Vertical & 458.7 \\
$3-3,120$ & 156.0 & Vertical & 234.0 \\
$3-3,130$ & 156.0 & Vertical & 244.0 \\
$3-4,0$ & 156.5 & Vertical & 263.5 \\
$3-4,37$ & 157.0 & Vertical & 361.1 \\
$3-4,70$ & 157.0 & Vertical & 439.2 \\
$3-4,130$ & 158.0 & Vertical & 439.2 \\
\hline & & &
\end{tabular}

tion, more expansion can occur on the top and bottom of a core under release of hydrostatic pressure.

When comparing the water-content data, a difference can be seen between the syringe sampling and the chunk method, the first one creating more voids when inserting the syringe. Scattering and a downward increase in density are absent as can be seen in Figure 12. On the contrary, a strong scattering in porosity data exists. 
Bulk Density, Porosity, and Water Content as Determined by the GRAPE and Syringe Methods, Site 296

\begin{tabular}{|c|c|c|c|c|c|c|c|c|c|c|c|}
\hline \multirow[b]{3}{*}{ Core } & \multirow[b]{3}{*}{ Section } & \multirow{3}{*}{$\begin{array}{l}\text { Diameter } \\
\text { (in.) }\end{array}$} & & & \multirow[b]{3}{*}{ Lithology } & \multicolumn{2}{|c|}{ GRAPE } & \multicolumn{3}{|c|}{ Syringe } & \multirow[b]{3}{*}{ Remarks } \\
\hline & & & \multicolumn{2}{|c|}{ Interval $(\mathrm{cm})$} & & \multirow{2}{*}{$\begin{array}{c}\text { Bulk } \\
\text { Density } \\
(\mathrm{g} / \mathrm{cc})\end{array}$} & \multirow{2}{*}{$\begin{array}{c}\text { Porosity } \\
(\%)\end{array}$} & \multirow{2}{*}{$\begin{array}{c}\text { Water } \\
\text { Content } \\
(\%)\end{array}$} & \multirow{2}{*}{$\begin{array}{c}\text { Bulk } \\
\text { Density } \\
(\mathrm{g} / \mathrm{cc})\end{array}$} & \multirow{2}{*}{$\begin{array}{c}\text { Porosity } \\
(\%)\end{array}$} & \\
\hline & & & GRAPE & Syringe & & & & & & & \\
\hline \multirow[t]{2}{*}{1} & 3 & 2.25 & A & $\begin{array}{c}70 \\
140\end{array}$ & Foram-clay nanno ooze & 1.57 & 70.8 & 46.15 & 1.52 & 70.03 & \\
\hline & 4 & 2.25 & A & $144-150$ & $\begin{array}{l}\text { Foram-clay nanno ooze } \\
\text { Foram-clay nanno ooze }\end{array}$ & 1.57 & 70.8 & 43.56 & 1.54 & 67.23 & \\
\hline \multirow[t]{3}{*}{2} & 2 & 2.65 & $50-150$ & 110 & Foram-clay nanno ooze & 1.54 & 72.7 & 48.59 & 1.51 & 73.31 & \\
\hline & 5 & & & $144-150$ & Foram-clay nanno ooze & & & 40.73 & 1.59 & 64.71 & \\
\hline & 6 & & & 40 & Foram-clay nanno ooze & & & 42.54 & 1.63 & 69.40 & D \\
\hline \multirow[t]{3}{*}{3} & 2 & 2.65 & A & & Foram-clay nanno ooze & 1.64 & 66.2 & & & & \\
\hline & 3 & 2.65 & A & 110 & Foram-clay nanno ooze & 1.61 & 68.2 & 43.19 & 1.27 & 54.66 & D \\
\hline & 4 & 2.65 & A & & Foram-clay nanno ooze & 1.63 & 66.8 & & & & \\
\hline \multirow[t]{3}{*}{4} & 2 & 2.65 & A & 110 & Foram-clay nanno ooze & 1.55 & 72.1 & 48.42 & 1.49 & 72.29 & D \\
\hline & 3 & 2.65 & A & & Foram-clay nanno ooze & 1.57 & 70.8 & & & & \\
\hline & 4 & 2.65 & A & & Foram-clay nanno ooze & 1.53 & 73.4 & & & & \\
\hline \multirow[t]{4}{*}{5} & 2 & 2.65 & A & & Foram-clay nanno ooze & 1.57 & 70.8 & & & & \\
\hline & 3 & & & 40 & Foram-clay nanno ooze & & & 42.94 & 1.57 & 67.20 & \\
\hline & & & & $144-150$ & Clayey nanno ooze & & & 41.38 & 1.61 & 66.51 & \\
\hline & 4 & 2.65 & A & & Clayey nanno ooze & 1.63 & 66.8 & & & & \\
\hline \multirow[t]{2}{*}{6} & 4 & 2.65 & A & 40 & Foram-clay nanno ooze & 1.64 & 66.2 & 42.31 & 1.58 & 66.66 & \\
\hline & 5 & 2.65 & A & & Foram-clay nanno ooze & 1.65 & 64.9 & & & & \\
\hline \multirow[t]{2}{*}{7} & 2 & 2.65 & A & 40 & Foram-clay nanno ooze & 1.56 & 71.4 & 44.59 & 1.52 & 67.95 & \\
\hline & 4 & 2.65 & A & & Clayey nanno ooze & 1.59 & 69.5 & & & & \\
\hline 8 & 3 & 2.65 & A & 40 & Clayey nanno ooze & 1.63 & 66.8 & 42.67 & 1.54 & 65.63 & \\
\hline & 4 & 2.56 & A & 110 & Clayey nanno ooze & 1.67 & 64.2 & 38.32 & 1.65 & 63.29 & \\
\hline 9 & 2 & 2.65 & $0-50$ & & Foram-clay nanno ooze & 1.68 & 63.6 & & & & \\
\hline & & 2.65 & $50-150$ & 110 & Foram-clay nanno ooze & 1.63 & 66.8 & 41.53 & 1.61 & 66.69 & \\
\hline & 5 & 2.65 & A & 110 & Foram-clay nanno ooze & 1.63 & 66.8 & 44.14 & 1.55 & 68.54 & \\
\hline 10 & 3 & 2.65 & A & 40 & Clay micarb nanno ooze & 1.58 & 70.2 & 46.75 & 1.53 & 71.34 & \\
\hline & & & & $144-150$ & Clay micarb nanno ooze & & & 41.36 & 1.61 & 66.46 & \\
\hline & 6 & 2.65 & A & 40 & Clayey nanno ooze & 1.65 & 65.6 & 42.58 & 1.58 & 67.40 & \\
\hline 11 & 3 & & & 110 & Clayey nanno ooze & & & 44.99 & 1.54 & 69.26 & \\
\hline & 4 & 2.65 & A & & Clayey nanno ooze & 1.59 & 69.5 & & & & \\
\hline 12 & 5 & 2.65 & A & 75 & Clayey nanno ooze & 1.64 & 66.2 & 42.56 & 1.56 & 66.23 & \\
\hline 13 & 2 & 2.65 & AI & & Clayey nanno ooze & 1.64 & 66.2 & & & & \\
\hline & 3 & 2.65 & AI & 40 & Clayey nanno ooze & 1.62 & 67.5 & 43.04 & 1.55 & 66.91 & \\
\hline 14 & 1 & 2.65 & AI & & Clayey nanno ooze & 1.55 & 72.1 & & & & \\
\hline & 5 & 2.65 & AI & 40 & Clayey nanno ooze & 1.57 & 70.8 & 54.89 & 1.39 & 76.54 & \\
\hline 15 & 2 & 2.65 & A & & Clayey nanno ooze & 1.63 & 66.8 & & & & \\
\hline & 3 & & & $144-150$ & Clayey nanno ooze & & & 41.89 & 1.56 & 65.54 & \\
\hline & 4 & 2.65 & A & & Clayey nanno ooze & 1.68 & 63.6 & & & & \\
\hline 16 & 3 & 2.65 & A & 40 & Clayey nanno ooze & 1.68 & 63.6 & 39.69 & 1.63 & 64.85 & \\
\hline & 5 & 2.65 & A & 40 & Clayey nanno ooze & 1.70 & 62.3 & 37.42 & 1.66 & 61.94 & \\
\hline 17 & 2 & 2.65 & $0-75$ & & Clayey nanno ooze & 1.69 & 62.9 & & & & \\
\hline & & & $75-150$ & & Clayey nanno ooze & 1.72 & 60.9 & & & & \\
\hline & 5 & 2.65 & A & 40 & Clayey nanno ooze & 1.73 & 60.3 & 37.58 & 1.65 & 61.96 & \\
\hline & & & & 110 & Clayey nanno ooze & & & 34.93 & 1.73 & 60.34 & \\
\hline 18 & 2 & 2.65 & AI & 110 & Clayey nanno ooze & 1.73 & 60.3 & 38.34 & 1.51 & 57.90 & \\
\hline
\end{tabular}




\begin{tabular}{|c|c|c|c|c|c|c|c|c|c|c|c|}
\hline 19 & 2 & 2.65 & A & 40 & Clayey nanno ooze & 1.63 & 66.8 & 42.21 & 1.54 & 64.92 & \\
\hline & 5 & 2.65 & A & & Clayey nanno ooze & 1.67 & 64.2 & & & & \\
\hline \multirow[t]{3}{*}{20} & 2 & 2.65 & $0-75$ & & Clayey nanno ooze & 1.75 & 59.0 & & & & \\
\hline & 3 & & $75-150$ & & Clayey nanno ooze & 1.55 & & & & & \\
\hline & & & & $\begin{array}{l}144-150 \\
144-150\end{array}$ & $\begin{array}{l}\text { Clayey nanno ooze } \\
\text { Clayey nanno ooze }\end{array}$ & & & $\begin{array}{l}44.27 \\
48.72\end{array}$ & $\begin{array}{l}1.52 \\
1.46\end{array}$ & $\begin{array}{l}67.11 \\
70.94\end{array}$ & \\
\hline 21 & 3 & 2.65 & A & & Clayey nanno ooze (chalky) & 1.63 & 66.8 & & & & \\
\hline \multirow[t]{3}{*}{22} & 3 & 2.65 & AI & & Clayey nanno ooze (chalky) & 1.54 & 72.7 & & & & \\
\hline & 5 & 2.65 & $0-75$ & & Clayey nanno ooze (chalky) & 1.55 & 72.1 & & & & \\
\hline & & 2.65 & $75-150$ & & Clayey nanno ooze (chalky) & 1.74 & 59.6 & & & & \\
\hline \multirow[t]{2}{*}{23} & 2 & 2.65 & $0-75$ & & Clayey nanno ooze & 1.60 & 68.8 & & & & \\
\hline & & 2.65 & $75-150$ & & Clay nanno ooze-chalk & 1.72 & 60.9 & & & & \\
\hline 24 & 3 & 2.65 & A & & Clay nanno ooze-chalk & 1.71 & 61.6 & & & & \\
\hline \multirow[t]{4}{*}{25} & 2 & 2.65 & $\begin{array}{c}0-75 \\
75-150\end{array}$ & & Clayey nanno ooze & 1.58 & $\begin{array}{l}70.2 \\
65.6\end{array}$ & & & & \\
\hline & 3 & & $75-150$ & $144-150$ & $\begin{array}{l}\text { Clayey nanno ooze-chalk } \\
\text { Clayey nanno ooze-chalk }\end{array}$ & 1.65 & 65.6 & 34.19 & 1.69 & 57.89 & \\
\hline & & & & $144-150$ & Clayey nanno ooze-chalk & & & 36.75 & 1.64 & 60.21 & Chunk method \\
\hline & 4 & 2.65 & A & & Clayey nanno ooze-chalk & 1.72 & 60.9 & & & & \\
\hline \multirow[t]{2}{*}{26} & 3 & 2.65 & A & & Clayey nanno ooze-chalk & 1.73 & 60.3 & & & & \\
\hline & 5 & 2.65 & A & & Clayey nanno ooze-chalk & 1.74 & 59.6 & & & & \\
\hline 27 & 3 & 2.65 & A & & Clayey nanno ooze-chalk & 1.70 & 62.3 & & & & \\
\hline \multirow[t]{2}{*}{28} & 4 & 2.65 & A & & Clayey nanno ooze-chalk & 1.66 & 64.9 & & & & \\
\hline & 5 & 2.65 & A & & Clayey nanno ooze-chalk & 1.66 & 64.9 & & & & \\
\hline \multirow[t]{2}{*}{29} & 2 & 2.65 & $\mathrm{AC}$ & & $\begin{array}{l}\text { Clayey nanno ooze-chalk } \\
\text { and ash }\end{array}$ & 1.63 & 66.8 & & & & \\
\hline & 5 & 2.65 & A & & Clayey nanno chalk & 1.70 & 62.3 & & & & \\
\hline \multirow[t]{3}{*}{30} & 3 & 2.65 & $\mathrm{AC}$ & & Clayey rad nanno chalk & 1.58 & 70.2 & & & & \\
\hline & 4 & & & $144-150$ & Clayey rad nanno chalk & & & 36.31 & 1.65 & 59.76 & Chunk method \\
\hline & 5 & 2.65 & A & & Clayey rad nanno chalk & 1.72 & 60.9 & & & & \\
\hline 31 & 2 & 2.65 & A & & Clayey nanno chalk & 1.72 & 60.9 & & & & \\
\hline 32 & 3 & 2.65 & A & & Clayey nanno chalk & 1.74 & 59.6 & & & & \\
\hline \multirow[t]{3}{*}{33} & 3 & 2.65 & 75 & & Clayey nanno chalk & 1.73 & 60.3 & & & & \\
\hline & 4 & 2.65 & AC & & Clayey nanno chalk & 1.70 & 62.3 & & & & \\
\hline & 5 & 2.65 & AC & $144-150$ & Clayey nanno chalk & 1.79 & 56.4 & 29.33 & 1.77 & 51.89 & Chunk method \\
\hline \multirow[t]{2}{*}{36} & 3 & 2.65 & AC & & Clayey nanno chalk & 1.72 & 60.9 & & & & \\
\hline & 5 & 2.65 & $\mathrm{AC}$ & & Clayey nanno chalk & 1.75 & 59.0 & & & & \\
\hline \multirow[t]{2}{*}{37} & 3 & 2.65 & $\mathrm{AC}$ & & Clayey nanno chalk & 1.73 & 60.3 & & & & \\
\hline & 5 & 2.65 & $\mathrm{AC}$ & & Clayey nanno chalk & 1.73 & 60.3 & & & & \\
\hline \multirow[t]{2}{*}{38} & 3 & 2.65 & $\mathrm{AC}$ & & Clayey nanno chalk & 1.70 & 62.3 & & & & \\
\hline & & 2.65 & 50 & & Volc. ash & 1.95 & 45.9 & & & & \\
\hline \multirow[t]{3}{*}{39} & 3 & 2.65 & AC & & Clayey nanno chalk & 1.59 & 69.5 & & & & Ash layers \\
\hline & 4 & 2.65 & $0-75$ & & Clayey nanno chalk & 1.63 & 66.8 & & & & Ash layers \\
\hline & & 2.65 & $75-150$ & & Clayey nanno chalk & 1.66 & 64.9 & & & & Ash layers \\
\hline \multirow[t]{3}{*}{40} & 1 & & & $143-150$ & Clay-ash-nanno chalk & & & 35.01 & 1.63 & 57.22 & Chunk method \\
\hline & 3 & 2.65 & AC & & Clay-ash-nanno chalk & 1.69 & 62.9 & & & & \\
\hline & 4 & 2.65 & $\mathrm{AC}$ & & Clay-ash-nanno chalk & 1.73 & 60.3 & & & & \\
\hline 41 & 3 & 2.65 & $\mathrm{AC}$ & & Clay-ash-nanno chalk & 1.67 & 64.2 & & & & \\
\hline 45 & 2 & & & $144-150$ & Ash rich nanno chalk & & & 34.44 & 1.68 & 58.00 & Chunk method \\
\hline 46 & 3 & 2.65 & AC & & Ash rich nanno chalk & 1.75 & 59.0 & & & & \\
\hline 52 & 1 & 2.4 & Piece 3 & $144-150$ & Clay-ash-nanno chalk & 1.79 & 56.4 & 32.29 & 1.74 & 56.33 & Chunk method \\
\hline & & 2.35 & Piece 13 & & Clay-ash-nanno chalk & 1.71 & 61.6 & & . & & \\
\hline 56 & 6 & 2.34 & AC & & Lapilli tuff & 2.09 & 36.8 & & & & \\
\hline
\end{tabular}

Note: $\mathrm{A}=$ average reading of a rather smooth GRAPE analog record. $\mathrm{AI}=$ average reading of an irregular GRAPE analog record. $\mathrm{AC}=\mathrm{average}$ reading of an

irregular GRAPE analog record from a core section consisting of chunks. $\mathrm{D}=$ doubtful value due to balance problems. 


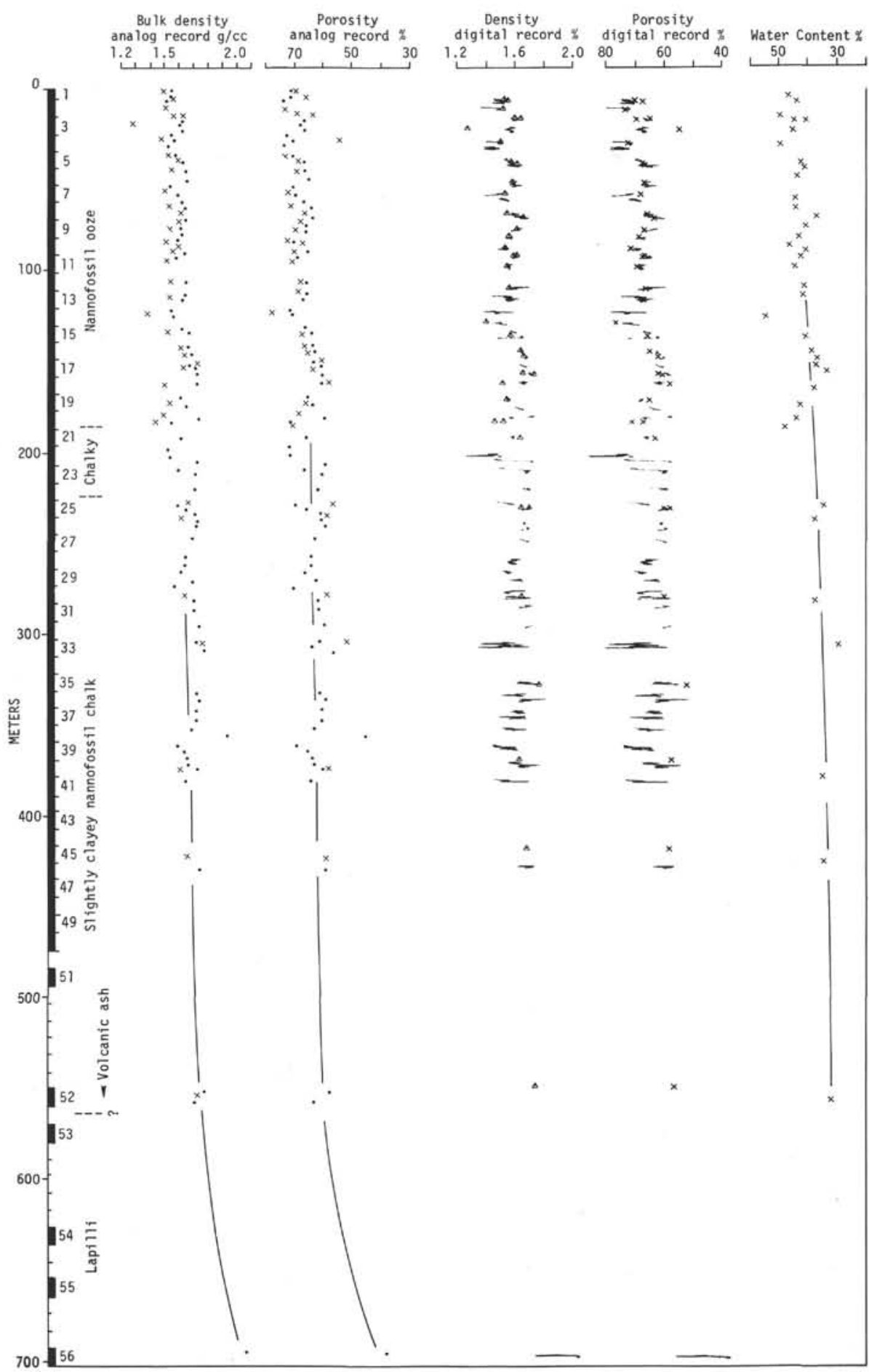

Figure 8. Plot of physical properties for Site 296. GRAPE analog record readings as well as computer plot are presented in addition to laboratory analyses (syringe and chunk methods). On the left the cores are given as black rectangles and the general lithology.

One piece of Core 10, Section 4, was measured on the GRAPE outside its liner. A bulk density of $1.83 \mathrm{~g} / \mathrm{cc}$ and porosity of $53.8 \%$ were calculated using the 2.65 in. diameter. The actual diameter was 2.45 in. which boosts the density up to $1.98 \mathrm{~g} / \mathrm{cc}$, and the porosity then becomes $43.9 \%$. However, not all diameters were constant but a general increase of all values by $0.1-0.15 \mathrm{~g} / \mathrm{cc}$ seems proper. This then places all laboratory values consistently lower than the GRAPE analog readings as has been normal for all other holes. 


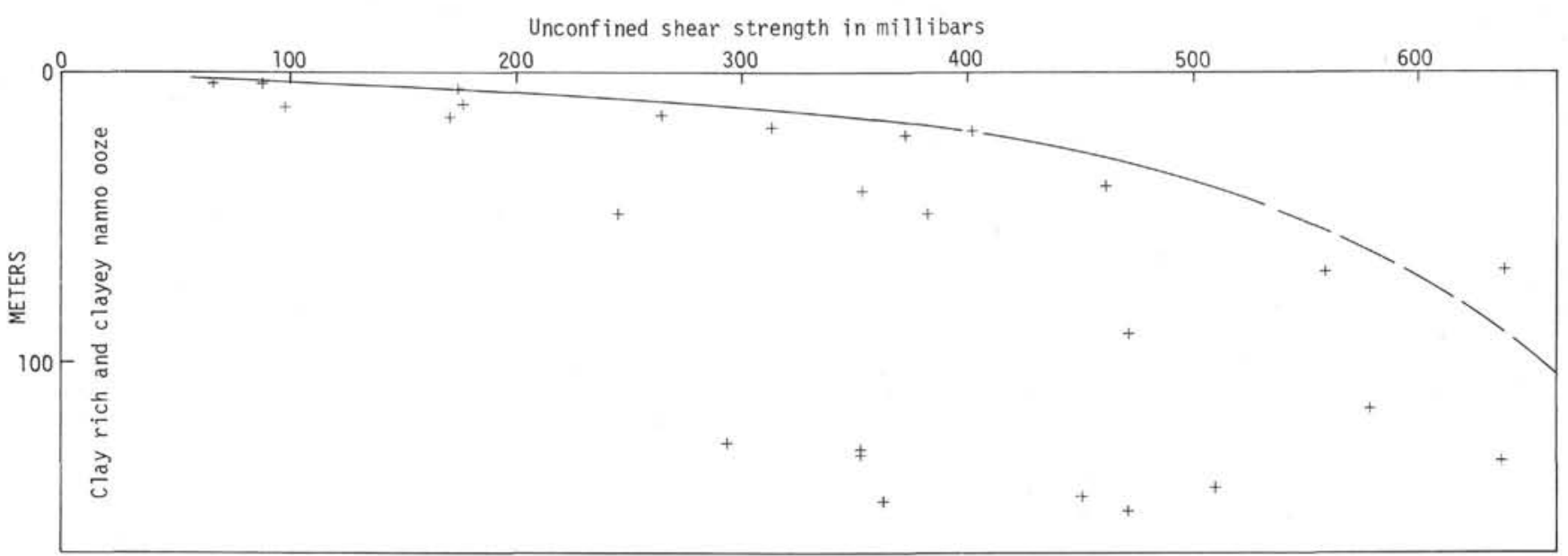

Figure 9. Plot of unconfined shear strength with depth, Site 296.

TABLE 13

Vane Shear Data, Site 296

\begin{tabular}{cccc}
\hline $\begin{array}{c}\text { Sample } \\
\text { (Interval in cm) }\end{array}$ & $\begin{array}{c}\text { Depth } \\
\text { (to nearest } \\
\text { half meter) }\end{array}$ & $\begin{array}{c}\text { Plane of } \\
\text { Measurement }\end{array}$ & $\begin{array}{c}\text { Shear } \\
\text { Strength } \\
\text { (mbar) }\end{array}$ \\
\hline $1-2,145$ & 3.5 & Vertical & 66.4 \\
$1-3,35$ & 4.0 & Vertical & 87.8 \\
$1-4,75$ & 6.0 & Vertical & 173.7 \\
$2-3,119$ & 11.0 & Vertical & 175.7 \\
$2-4,60$ & 12.0 & Vertical & 97.6 \\
$2-6,10$ & 14.5 & Vertical & 263.5 \\
$2-6,73$ & 15.0 & Vertical & 169.8 \\
$3-2,101$ & 22.0 & Vertical & 312.3 \\
$3-3,63$ & 23.0 & Vertical & 400.2 \\
$3-4,100$ & 25.0 & Vertical & 370.8 \\
$5-3,130$ & 43.0 & Vertical & 458.7 \\
$5-4,135$ & 44.5 & Vertical & 351.4 \\
$6-3,115$ & 50.5 & Vertical & 380.6 \\
$6-4,30$ & 51.5 & Vertical & 244.0 \\
$8-4,21$ & 71.5 & Vertical & 634.4 \\
$8-4,96$ & 72.5 & Vertical & 556.3 \\
$10-6,100$ & 91.5 & Vertical & 468.9 \\
$13-4,140$ & 120.5 & Vertical & 575.8 \\
$14-6,120$ & 129.5 & Vertical & 292.8 \\
$15-3,100$ & 134.5 & Vertical & 351.4 \\
$15-2,40$ & 132.0 & Vertical & 351.4 \\
$15-4,120$ & 136.0 & Vertical & 634.4 \\
$16-4,30$ & 145.0 & Vertical & 507.5 \\
$16-6,35$ & 148.0 & Vertical & 449.0 \\
$17-1,120$ & 152.0 & Vertical & 361.1 \\
$17-3,100$ & 155.0 & Vertical & 468.9 \\
\hline & & &
\end{tabular}

In Figure 12 no corrections of the analog readings have been used. Most values for bulk density from the shaly unit of this site are already higher than those from similar depths of other holes or they correspond to the higher values. The main reason for not using a correction factor is that larger errors may be entered than the analog readings present due to unknown variations in fissility.

\section{Vane Shear}

The sparse vane-shear data in this large-scale overturned anticline, formed by underthrusting of the adjacent trench sediments, indicate low shear strength at
130 meters but a rapid increase through the interval from 130 to $180 \mathrm{~m}$ (Table 17, Figure 13). The low shear strength at 130 meters could be an artifact of drilling deformation, but consolidation tests indicate that the material is underconsolidated (Trabant et al., this volume). Although a sharp gradient of strengthening may be spurious, the water content from 130 to 180 meters shows a spectacular decrease suggesting that the shear-strength values indeed may be representative. The obvious remolding due to structural deformation makes it difficult to compare the sparse shear-strength data from Site 298 with similar information from other sites.

\section{Site 299}

This site was located in the submarine canyon fan complex of the Tayama Channel in the northwest corner of the Yamato Basin, Sea of Japan (see Bouma, this volume). No distinct lithological changes were found in this basically silty clay series in which some forams, diatoms, and volcanic ash are scattered or in thin layers. Some sand and clay layers were also present. Thirtyeight cores were drilled representing 532 meters of section. The two bottom cores are high in volcanic ash (Table 18, Figure 14).

The density values show a minor increase with depth. The gassy nature of the cores from the lower part of the hole may account for the low density values. The scattering is rather large due to the varying lithologies. Cores dominated by sand give relative high density values. The data obtained by the syringe-chunk methods generally show trends similar to values calculated from the GRAPE analog records.

\section{Vane Shear}

Vane shear determinations (Figure 15, Table 19) were made entirely in silty clays and clayey silts. The enveloping curve shows a concave downward shape indicating a decreasing rate of strengthening with depth.

\section{Site 301}

The location of this site was selected in such a way that it was furthest away from any of the major channels 
TABLE 14

Bulk Density, Porosity, and Water Content as Determined by the GRAPE and Syringe Methods, Site 297

\begin{tabular}{|c|c|c|c|c|c|c|c|c|c|c|c|}
\hline \multirow[b]{3}{*}{ Core } & \multirow[b]{3}{*}{ Section } & \multirow{3}{*}{$\begin{array}{l}\text { Diameter } \\
\text { (in.) }\end{array}$} & & & \multirow[b]{3}{*}{ Lithology } & \multicolumn{2}{|c|}{ GRAPE } & \multicolumn{3}{|c|}{ Syringe } & \multirow[b]{3}{*}{ Remarks } \\
\hline & & & \multicolumn{2}{|c|}{ Interval $(\mathrm{cm})$} & & $\begin{array}{c}\text { Bulk } \\
\text { Density }\end{array}$ & & $\begin{array}{l}\text { Water } \\
\text { Content }\end{array}$ & $\begin{array}{c}\text { Bulk } \\
\text { Density }\end{array}$ & & \\
\hline & & & GRAPE & Syringe & & & (\%) & & $(\mathrm{g} / \mathrm{cc})$ & $(\%)$ & \\
\hline \multirow[t]{4}{*}{3} & 1 & & & $144-150$ & Diatom-ash-clay & & & 53.66 & 1.41 & 75.60 & \\
\hline & 2 & 2.65 & $0-75$ & & Diatom-rich clay & 1.48 & 76.7 & & & & Some ash \\
\hline & 3 & $\begin{array}{l}2.65 \\
2.65\end{array}$ & 75-150 & & Diatom-rich clay & 1.52 & 74.1 & & & & \\
\hline & $\begin{array}{l}3 \\
2\end{array}$ & & A & & Diatom-ash-clay & 1.49 & 76.1 & & & & \\
\hline \multirow[t]{2}{*}{4} & $\begin{array}{l}2 \\
5\end{array}$ & $\begin{array}{l}2.65 \\
2.65\end{array}$ & $\underset{0-75}{A}$ & 40 & $\begin{array}{l}\text { Diatom-ash-clay } \\
\text { Diatom-ash-clay }\end{array}$ & $\begin{array}{l}1.51 \\
1.58\end{array}$ & $\begin{array}{l}74.7 \\
70.2\end{array}$ & 43.41 & 1.58 & 68.74 & \\
\hline & & 2.65 & $75-150$ & 70 & Diatom-ash-clay & 1.60 & 68.8 & & & & \\
\hline \multirow[t]{3}{*}{5} & 2 & 2.65 & A & & Clay-rich nanno ooze & 1.51 & 74.7 & & & & \\
\hline & 4 & & & $144-150$ & Clay-rich nanno ooze & & & 45.60 & 1.54 & 70.17 & \\
\hline & 5 & 2.65 & A & 40 & Clay-rich nanno ooze & 1.59 & 69.5 & 44.89 & 1.54 & 69.27 & \\
\hline \multirow[t]{4}{*}{6} & 2 & 2.65 & $0-80$ & & Clay-rich nanno ooze & 1.52 & 74.1 & & & & \\
\hline & & 2.65 & $80-150$ & & Nanno-rich silty clay & 1.54 & 72.7 & & & & \\
\hline & 4 & 2.65 & A & 40 & Nanno-rich silty clay & 1.58 & 70.2 & 41.40 & 1.56 & 64.60 & \\
\hline & 5 & & & $144-150$ & Nanno-rich silty clay & & & 46.76 & 1.57 & 73.40 & \\
\hline 7 & 3 & 2.65 & $0-75$ & & Clayey silt & 1.47 & 77.4 & & & & \\
\hline & & & $75-150$ & & Clayey silt & 1.63 & 66.8 & & & & \\
\hline & 4 & 2.65 & A & 40 & Clayey silt & 1.58 & 70.2 & 42.36 & 1.60 & 67.91 & \\
\hline 8 & 3 & 2.65 & A & & Clayey silt & 1.62 & 67.5 & & & & \\
\hline & & & $72-78$ & & Volc. ash & 1.80 & 55.7 & & & & \\
\hline & 5 & & & $144-150$ & Nanno-rich clayey silt & & & 43.72 & 1.57 & 68.77 & \\
\hline & 6 & 2.65 & A & & Clayey silt & 1.62 & 67.5 & & & & \\
\hline 9 & 2 & 2.65 & A & & Clayey silt & 1.64 & 66.2 & & & & \\
\hline & 3 & 2.65 & A & 33 & Clayey silt & 1.62 & 67.5 & 42.70 & 1.58 & 67.51 & \\
\hline 10 & 3 & 2.65 & $0-75$ & & Clayey silt & 1.55 & 72.1 & & & & \\
\hline & & 2.65 & $75-150$ & & Clayey silt & 1.58 & 70.2 & & & & \\
\hline & 5 & & & $144-150$ & Clayey silt & & & 42.54 & 1.58 & 67.33 & \\
\hline & 6 & 2.65 & A & 29 & Clayey silt & 1.58 & 70.2 & 44.06 & 1.54 & 67.80 & \\
\hline 11 & 2 & 2.65 & $0-75$ & & Clayey silt & 1.50 & 75.4 & & & & \\
\hline & & 2.65 & $75-150$ & & Clayey silt & 1.58 & 70.2 & & & & \\
\hline & 3 & & & 30 & Clayey silt & & & 43.64 & 1.54 & 67.03 & \\
\hline & & & & 60 & Clayey silt & & & 43.34 & 1.57 & 67.94 & \\
\hline & & & & 120 & Clayey silt & & & 44.50 & 1.50 & 66.67 & Chunk method \\
\hline & & & & $144-150$ & Clayey silt & & & 42.38 & 1.58 & 66.89 & \\
\hline & 4 & 2.65 & A & & Clayey silt & 1.60 & 68.8 & & & & Volc, ash layers \\
\hline 12 & 2 & & & $144-150$ & Clay & & & 42.21 & 1.55 & 65.46 & \\
\hline & 3 & & & 25 & Clay & & & 41.31 & 1.54 & 63.72 & Chunk method \\
\hline 13 & 1 & & & 112 & Clay & & & 44.54 & 1.52 & 67.49 & Chunk method \\
\hline 14 & 2 & 2.65 & $0-75$ & & Clay & 1.77 & 57.7 & & & & \\
\hline & & 2.65 & $75-150$ & & Clay & 1.82 & 54.4 & & & & \\
\hline & 5 & 2.65 & A & $144-150$ & Clay & 1.82 & 54.4 & 29.86 & 1.86 & 55.40 & \\
\hline 15 & 2 & 2.65 & A & & Clay & 1.76 & 58.4 & & & & \\
\hline & 4 & 2.65 & $0-120$ & & Clay & 1.82 & 54.4 & & & & \\
\hline & & & $120-160$ & & Clayey sand & 1.96 & 45.2 & & $1:$ & & \\
\hline 16 & 2 & 2.65 & $\mathrm{AI}$ & 35 & Clay/silt-rich sand & 2.10 & 36.1 & 15.76 & 1.76 & 27.80 & \\
\hline 17 & 2 & & & $144-150$ & Peat-rich ashey silt & & & 14.51 & 2.08 & 30.23 & \\
\hline & 3 & 2.65 & $0-50$ & & Clay/silt-rich sand & 2.12 & 34.8 & & & & AI \\
\hline & & 2.65 & $50-100$ & & Sandy clay & 2.05 & 39.3 & & & & AI \\
\hline 18 & 1 & & & $144-150$ & Clay/silt-rich sand & & & 19.96 & 2.03 & 36.54 & \\
\hline & 2 & 2.65 & AI & & Clay/silt-rich sand & 2.05 & 39.3 & & & & \\
\hline 20 & 2 & & & $144-150$ & Clay/silt-rich sand & & & 22.92 & 1.70 & 39.09 & \\
\hline 22 & 2 & 2.65 & AI & & Clay/silt-rich sand & 1.95 & 45.9 & & & & \\
\hline & 4 & 2.65 & AI & & Clay/silt-rich sand & 1.98 & 43.9 & & & & \\
\hline 23 & 3 & 2.65 & AI & $144-150$ & Clay & 2.02 & 41.3 & 22.56 & 1.96 & 44.12 & Chunk method \\
\hline 23 & 4 & 2.65 & $0-80$ & & Clay/silt-rich sand & 1.99 & 43.7 & & & & \\
\hline & & 2.65 & $80-150$ & & Clay & 1.90 & 49.2 & & & & \\
\hline 24 & 1 & & & $144-150$ & Clay & & & 36.97 & 1.61 & 59.46 & Chunk method \\
\hline 25 & 3 & & & 58 & Volc. ash & & & 28.94 & 1.68 & 48.75 & Chunk method \\
\hline & 4 & 2.65 & A & & Volc. ash & 1.65 & 65.6 & & & & \\
\hline & 6 & 2.65 & A & & Volc. ash & 1.65 & 65.6 & & & & \\
\hline 26 & 1 & & & 4 & Volc. ash with clay & & & 23.43 & 1.91 & 44.69 & Chunk method \\
\hline
\end{tabular}

Note: $\mathrm{A}=$ average reading of a rather smooth GRAPE analog record. $\mathrm{AI}=$ average reading of an irregular GRAPE analog record. 


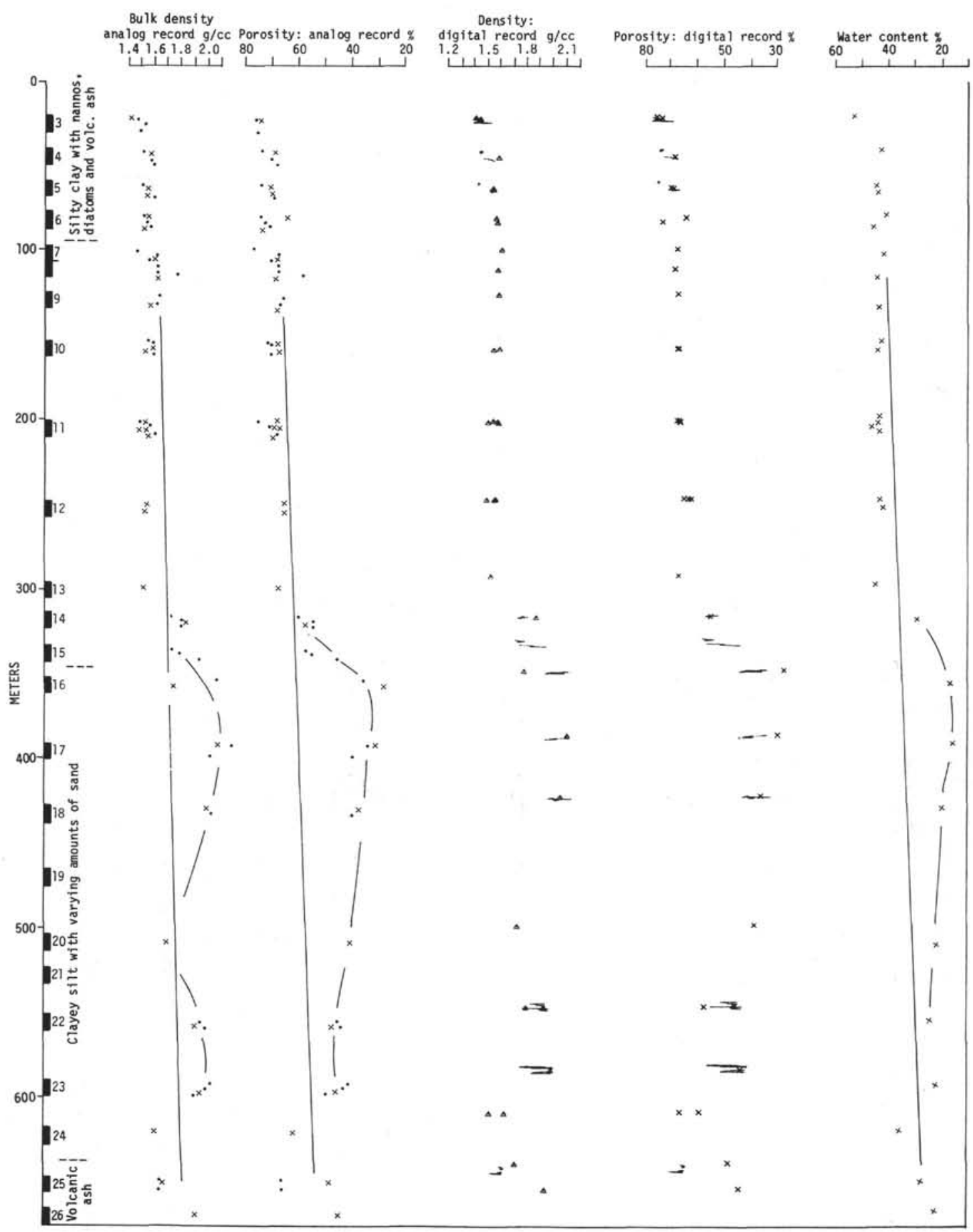

Figure 10. Plot of physical properties for Site 297. GRAPE analog record readings as well as computer plot are presented in addition to laboratory analyses (syringe and chunk methods). On the left the cores are given as black rectangles and the general lithology. 


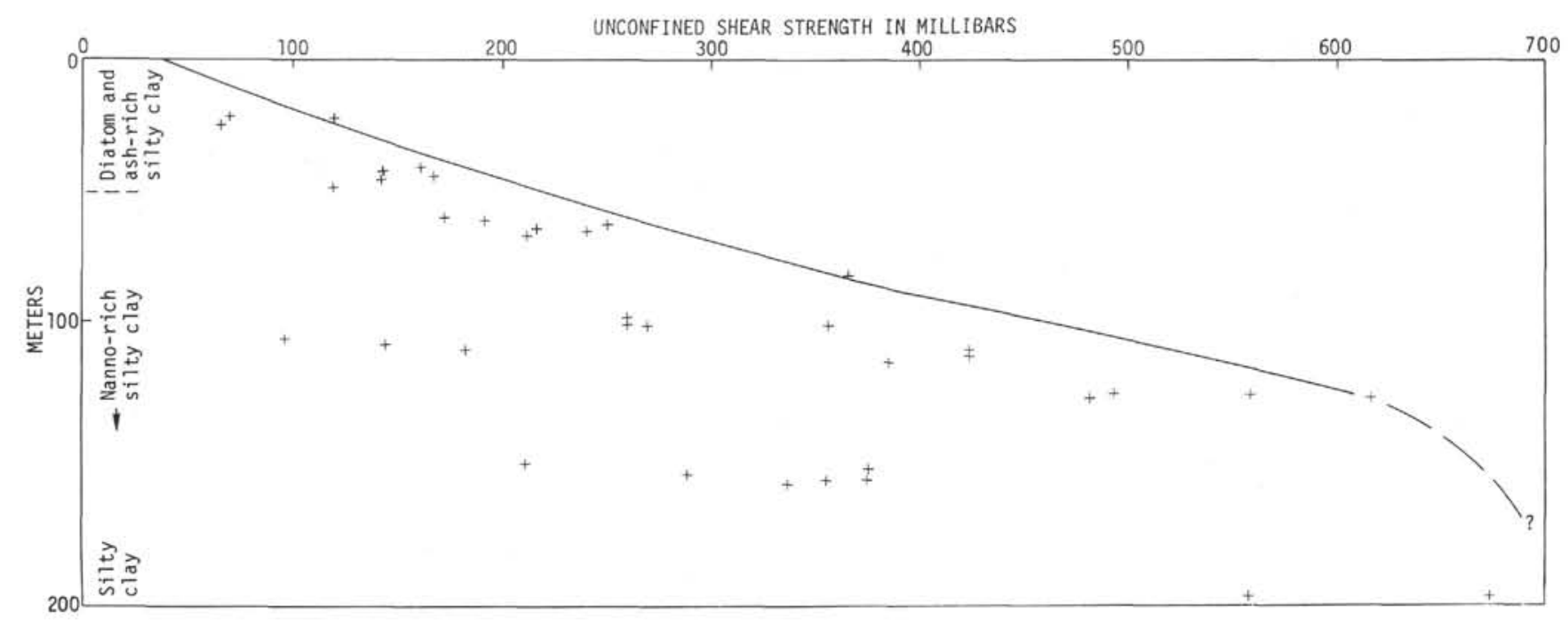

Figure 11. Plot of unconfined shear strength with depth, Site 297.

TABLE 15

Vane Shear Data, Site 297

\begin{tabular}{lccc}
\hline $\begin{array}{c}\text { Sample } \\
\text { (nterval in cm) }\end{array}$ & $\begin{array}{c}\text { Depth } \\
\text { (to nearest } \\
\text { half meter) }\end{array}$ & $\begin{array}{c}\text { Plane of } \\
\text { Measurement }\end{array}$ & $\begin{array}{c}\text { Shear } \\
\text { Strength } \\
\text { (mbar) }\end{array}$ \\
\hline $3-1,120$ & 26.0 & Vertical & 68.8 \\
$3-2,80$ & 27.5 & Vertical & 118.5 \\
$3-3,145$ & 29.5 & Vertical & 65.0 \\
$4-1,145$ & 41.0 & Vertical & 160.6 \\
$4-2,140$ & 42.5 & Vertical & 141.5 \\
$4-3,145$ & 44.0 & Vertical & 166.4 \\
$4-4,145$ & 45.5 & Vertical & 141.5 \\
$4-6,145$ & 48.5 & Vertical & 118.5 \\
$5-1,120$ & 59.5 & Vertical & 171.1 \\
$5-2,115$ & 61.0 & Vertical & 191.2 \\
$5-3,100$ & 62.5 & Vertical & 248.6 \\
$5-4,120$ & 64.0 & Vertical & 215.1 \\
$5-5,50$ & 65.0 & Vertical & 239.0 \\
$5-6,95$ & 67.0 & Vertical & 210.3 \\
$6-4,29$ & 83.0 & Vertical & 363.3 \\
$7-2,77$ & 102.0 & Vertical & 258.1 \\
$7-3,120$ & 103.0 & Vertical & 353.7 \\
$7-3,132$ & 104.0 & Vertical & 258.1 \\
$7-4,75$ & 105.0 & Vertical & 267.7 \\
$8-1,80$ & 107.0 & Vertical & 95.6 \\
$8-2,145$ & 109.0 & Vertical & 143.4 \\
$8-3,138$ & 110.5 & Vertical & 181.6 \\
$8-4,6$ & 110.5 & Vertical & 420.6 \\
$8-5,76$ & 113.0 & Vertical & 420.6 \\
$8-6,145$ & 115.0 & Vertical & 382.4 \\
$9-1,138$ & 131.0 & Vertical & 489.6 \\
$9-2,70$ & 132.0 & Vertical & 554.5 \\
$9-2,146$ & 132.5 & Vertical & 611.8 \\
$9-3,5$ & 132.5 & Vertical & 478.0 \\
$10-1,26$ & 153.0 & Vertical & 210.3 \\
$10-2,71$ & 154.5 & Vertical & 372.8 \\
$10-3,142$ & 157.0 & Vertical & 286.8 \\
$10-4,135$ & 161.0 & Vertical & 353.7 \\
$10-5,6$ & 161.0 & Vertical & 372.8 \\
$10-6,48$ & 161.5 & Vertical & 334.6 \\
$11-3,41$ & 207.5 & Vertical & 554.5 \\
$11-3,67$ & 207.5 & Vertical & 669.2 \\
\hline & & & \\
\hline & & & \\
\hline & & & \\
& & &
\end{tabular}

feeding the abyssal plain. Twenty cores were taken over a 497-meter interval. The upper 7 cores, representing 240.5 meters of sediment column, contained primarily silty clays and clays. Minor interbeddings of sandy silts, silty sands, clayey sands, sands, and volcanic ash were encountered. Diatoms, radiolarians, sponge spicules, and silicoflagellates were common minor constituents. Below this unit a clayey diatomite, grading into a diatomaceous claystone, was found. Clay-mineral content varies from $30 \%$ to $54 \%$ and diatomite content from $30 \%$ to $50 \%$.

Presence of gas was normal in most of the cores, resulting in many large and small expansion cracks making it difficult to carry out physical-property measurements. Syringe samples without cracks could not be collected at all except for the upper cores.

Most core sections had a slight difference between top and bottom density values. Very often the middle section was too broken up to obtain any rational curve at all (Table 20). Consequently, a large scattering of plotted data is to be expected (Figure 16). Using the limited number of data points and eliminating the higher values in Core 5, a minor downhole increase in density results.

Although the GRAPE values are doubtful, the syringe and chunk analyses are considered highly inaccurate. This becomes very obvious when viewing the water-content plots.

\section{Site 302}

This last hole of Leg 31 was drilled in 2399 meters of water on the Yamato Rise. A total of 18 cores was drilled representing 531.5 meters of section. The sediments were diatomaceous, except for both bottom cores. Lithologic variations enabled the shipboard sedimentologists to distinguish five units which is more detailed than that used for physical property studies. Core 18 consisted of volcanogenic material representing late Miocene volcanic activity which stratigraphically was followed by continuous pelagic sedimentation. 
TABLE 16

Bulk Density, Porosity, and Water Content as Determined by the GRAPE and Syringe Methods, Site 298

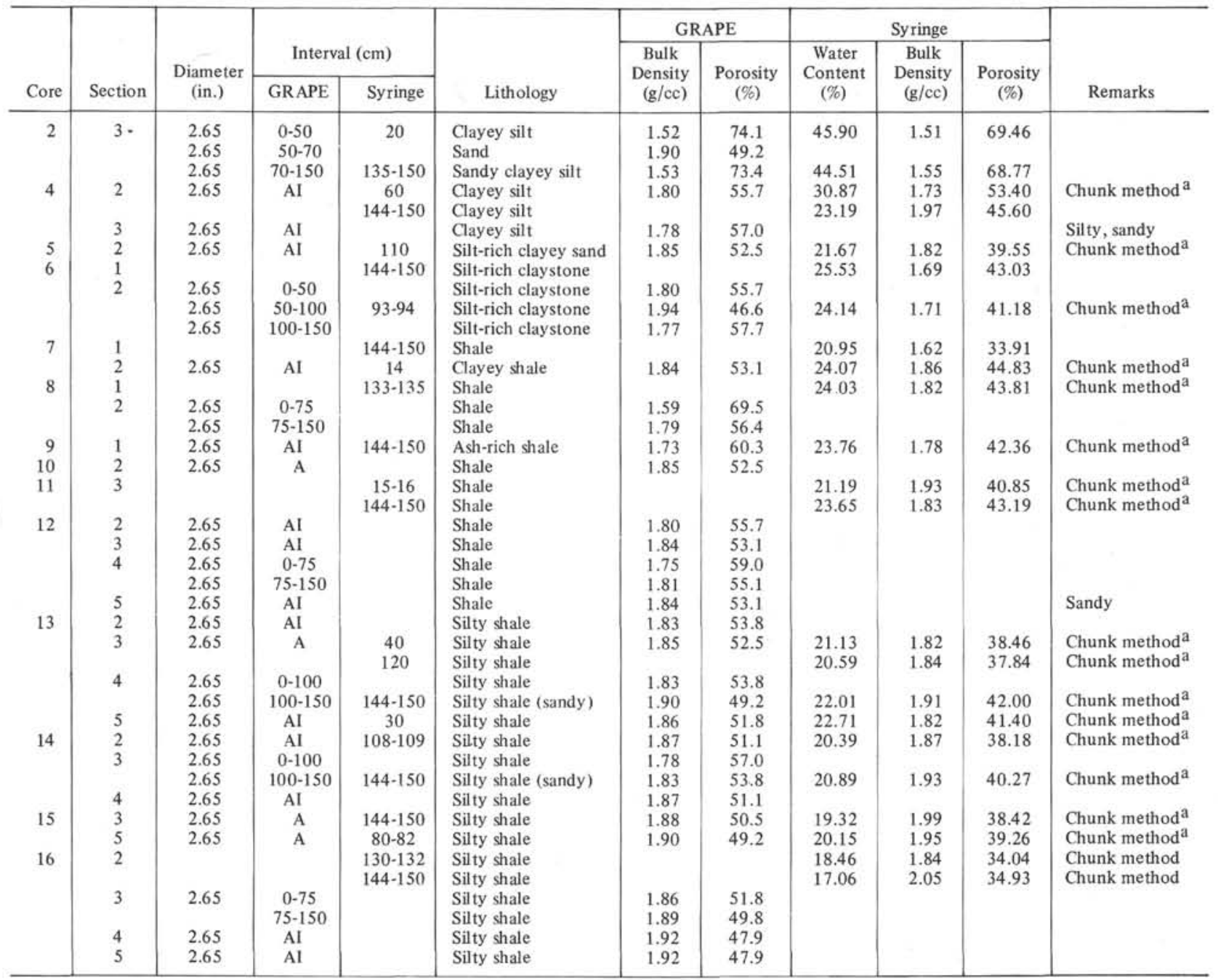

Note: $\mathrm{A}=$ average reading of a rather smooth GRAPE analog record. $\mathrm{AI}=$ average reading of an irregular GRAPE analog record.

${ }^{a}$ measurement may not be too accurate due to crumbly nature of samples resulting in possible loss of some small pieces during the analysis.

Variations in the type and amount of this type of deposition are reflected in the sediments.

From Cores 2 through 5 a minor downhole increase in density, coupled with medium scattering, can be observed (Table 21, Figure 17). This is followed by almost constant density, porosity, and water-content values through Core 14 . The zone of nearly constant values distinguishes itself from the top five cores by minimum scattering.

The diatomites have low bulk-density values and indicate the trend the physical properties follow below Core 14. Two pieces from Core 17, Section 2, were measured outside the liner, presenting values for density of 1.55 and $1.51 \mathrm{~g} / \mathrm{cc}$. By using the actual diameters, 2.35 and 2.37 in., respectively, the density values become 1.37 and $1.35 \mathrm{~g} / \mathrm{cc}$. This places their plots straight in line with those of the overlying unit.
In the zone where there are nearly constant values with depth, very little scattering occurs and values are lower than others obtained during Leg 31 . The values place these diatomaceous oozes in a category apart. Consolidation may take place initially, but overburden seems to have no effect (Trabant et al., this volume). In Figure 17 two mean lines are given, one for the upper five cores and one for the underlying ones.

\section{Vane Shear}

The Site 302 shear-strength data also show two trends (Figure 18, Table 22). Down to 80 meters the shear strength increases rapidly with depth; whereas, below this depth there is both a marked decrease in absolute strength and a decrease in the rate of increase of shear strength. This sharp discontinuity is apparently due to a transition from a predominantly clayey lithology to a 


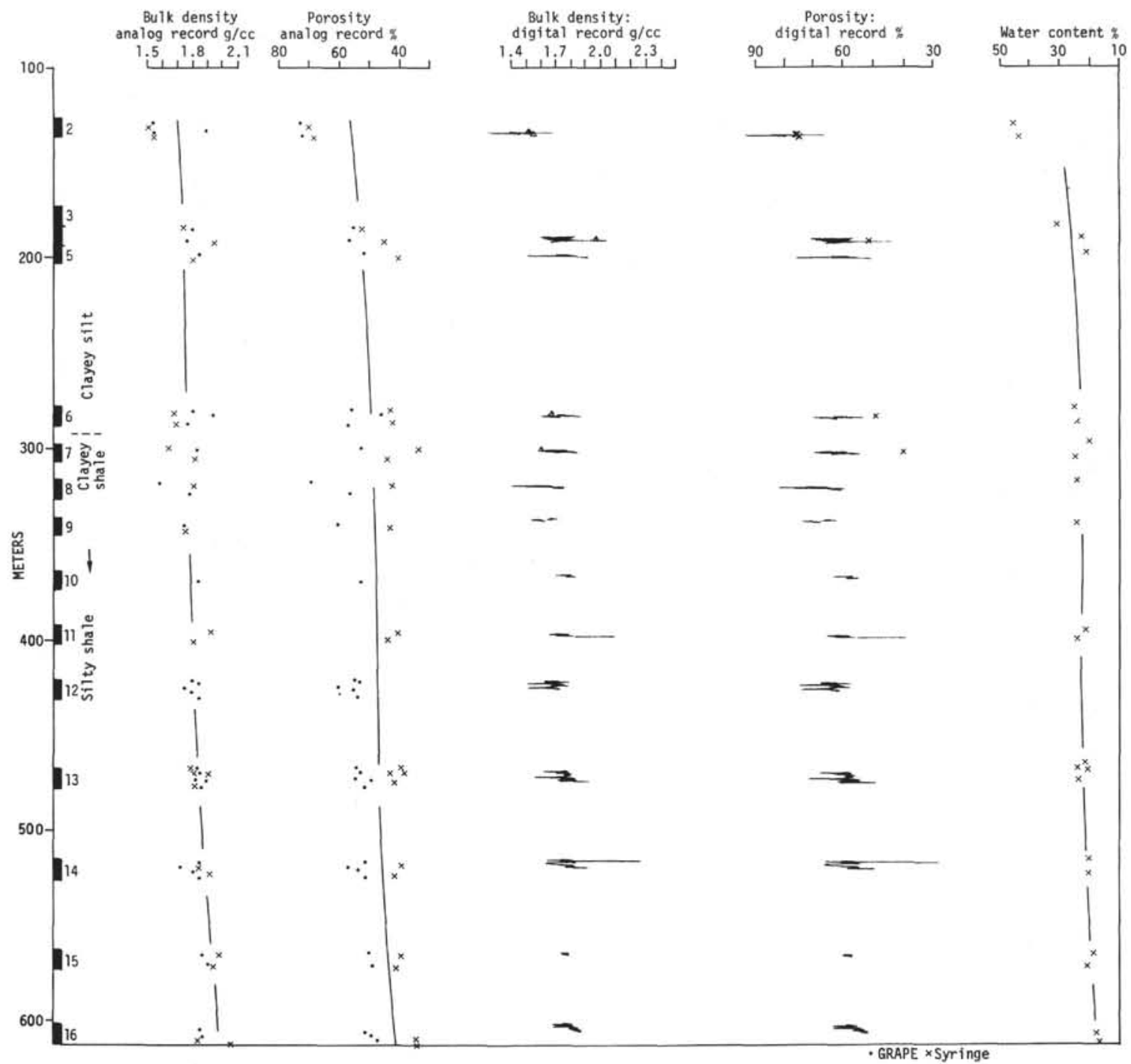

Figure 12. Plot of physical properties for Site 298. GRAPE analog record readings as well as computer plot are presented in addition to laboratory analyses (syringe and chunk methods). On the left the cores are given in black rectangles and the general lithology.

diatom ooze. This decrease in shear strength also corresponds with an increase of porosity from about $75 \%$ to $80 \%$ (water content similarly changes from less than $50 \%$ to more than $55 \%$ ).

\section{CONCLUSIONS}

The GRAPE measurements as well as the syringe/chunk methods are routinely performed often without a geotechnically trained scientist involved. As a result the data collected can only be used to identify overall trends rather than for specifics. Most of the flaws in the techniques have been extensively discussed by Bennett and Keller (1973). Coring distortion is the most serious source of errors with regard to GRAPE measurements. Generally, a decrease in the degree of disturbance can be observed downward in each core due to the distance over which material has moved up into the core barrel as well as the time it was subjected to drilling vibration. Once the sediment becomes more consolidated these effects decrease in magnitude. Consequently, the lowest sections should be measured only or, if more sections were measured, their results should be disregarded or handled very carefully based on distrubance observations from split sections. Also more notice should be given to breaks and water pockets in the core sections, and frequent measurements should be made on the diameter of the core section. These factors account for a large amount of the scattering. In addition, one deals with drift in the GRAPE unit.

Weighing onboard ship can introduce large errors which add considerably to the inaccuracies in 1-cc syringe sample collection (see also Bennett and Keller, 1973). Inserting the syringe often creates hair cracks which can significantly influence the small volume.

\section{Bulk Density Versus Lithology}

Although bulk densities are well known for different types of materials, the combination of instrument drift, 
TABLE 17

Vane Shear Data, Site 298

\begin{tabular}{lllr}
\hline $\begin{array}{c}\text { Sample } \\
\text { (Interval in cm) }\end{array}$ & $\begin{array}{c}\text { Depth } \\
\text { (to nearest } \\
\text { half meter) }\end{array}$ & $\begin{array}{c}\text { Plane of } \\
\text { Measurement }\end{array}$ & $\begin{array}{c}\text { Shear } \\
\text { Strength } \\
\text { (mbar) }\end{array}$ \\
\hline $2-2,47$ & 132.5 & Vertical & 23.4 \\
$2-2,83$ & 132.5 & Vertical & 37.1 \\
$2-2,137$ & 133 & Vertical & 23.4 \\
$2-3,48$ & 134 & Vertical & 25.4 \\
$2-3,90$ & 134.5 & Vertical & 33.2 \\
$2-4,128$ & 136 & Vertical & 27.3 \\
$2-4,145$ & 136 & Vertical & 23.4 \\
$4-1,52$ & 189.5 & Vertical & 415.0 \\
$4-1,138$ & 190 & Vertical & 268.5 \\
$4-1,138$ & 190 & Vertical & 439.4 \\
$4-2,38$ & 191 & Vertical & 512.6 \\
$4-2,89$ & 191.5 & Vertical & 585.9 \\
$4-2,138$ & 192 & Vertical & 488.2 \\
$4-3,105$ & 193 & Vertical & 549.3 \\
$5-2,27$ & 202 & Vertical & 585.9 \\
$5-2,37$ & 202 & Vertical & 488.2 \\
6, CC & 288 & Horizontal & 341.7 \\
6, CC & 288 & Horizontal & 439.4 \\
6, CC & 288 & Horizontal & 366.2 \\
6, CC & 288 & Horizontal & 659.1 \\
\hline
\end{tabular}

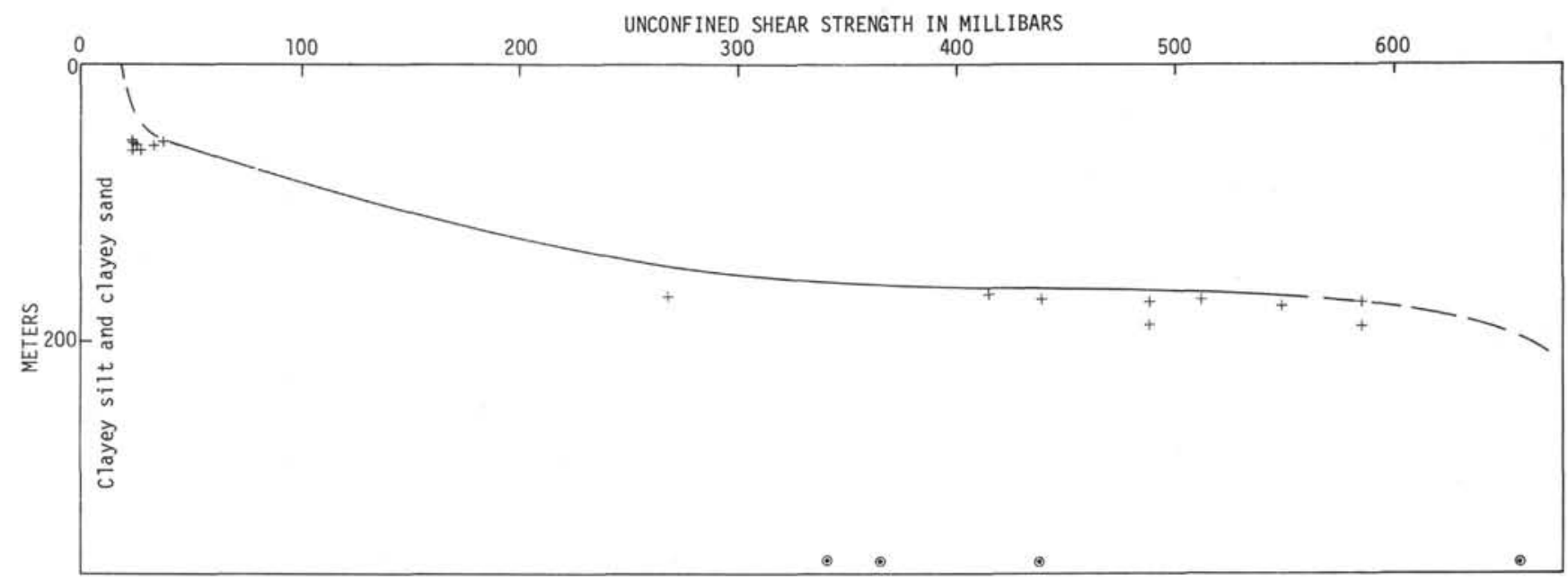

Figure 13. Plot of unconfined shear strength with depth, Site 298.

scattering due to sediment variations, and scattering based on artificial influences results in plots which do not reveal lithology. Figure 19 presents compilations of two sets of lithology groups with depth. One plot is made from all bulk density plots presented earlier per site where sediments were encountered that consist of any mixture of sand, silt, and clay as major constituents. It was found impossible to select accurately single lithologies due to insufficient size analyses. Such single lithology plots only become realistic if the degree of distortion is added. In Figure 19 the GRAPE analog readings are combined with the syringe/chunk data which accounts for even more scattering. A mean drawn through this plot presents a rather linear increase downward from about $1.4 \mathrm{~g} / \mathrm{cc}$ at the top to $1.84 \mathrm{~g} / \mathrm{cc}$ at the bottom. If diameters of the cores had been known better (see Test Results) and data from highly distorted sections eliminated, one would observe more parallel trends between various lithologies. The Site 298 plots would have been positioned at the outer right-hand side of the total plot and the Site 294/295 ones more on the left.

The other set of data points in Figure 19 is based on nannoplankton ooze/chalk with varying amounts of other components and on diatom ooze. The latter clearly has a lower density than the nannofossil series and displays a smaller increase in density with depth. A mean line for the diatom ooze is nearly vertical representing a value of $1.35 \mathrm{~g} / \mathrm{cc}$. Such a line for the nannofossil series starts at zero depth at about $1.55 \mathrm{~g} / \mathrm{cc}$ and may become as high as $2.09 \mathrm{~g} / \mathrm{cc}$ at 620 meters depth. If this is true the three points at Site 296 at about 545 meters depth are too low in value.

In general, it can be concluded that the bulk density, porosity, and water-content data are not accurate enough to draw precise conclusions. 
TABLE 18

Bulk Density, Porosity, and Water Content as Determined by the GRAPE and Syringe Methods, Site 299

\begin{tabular}{|c|c|c|c|c|c|c|c|c|c|c|c|}
\hline \multirow[b]{3}{*}{ Core } & \multirow[b]{3}{*}{ Section } & \multirow{3}{*}{$\begin{array}{l}\text { Diameter } \\
\text { (in.) }\end{array}$} & \multirow{2}{*}{\multicolumn{2}{|c|}{ Interval $(\mathrm{cm})$}} & & \multicolumn{2}{|c|}{ GRAPE } & \multicolumn{3}{|c|}{ Syringe } & \multirow[b]{3}{*}{ Remarks } \\
\hline & & & & & & \multirow{2}{*}{$\begin{array}{l}\text { Bulk } \\
\text { Density } \\
(\mathrm{g} / \mathrm{cc})\end{array}$} & \multirow{2}{*}{$\begin{array}{l}\text { Porosity } \\
(\%)\end{array}$} & \multirow{2}{*}{$\begin{array}{c}\text { Water } \\
\text { Content } \\
(\%)\end{array}$} & \multirow{2}{*}{$\begin{array}{c}\text { Bulk } \\
\text { Density } \\
(\mathrm{g} / \mathrm{cc})\end{array}$} & \multirow{2}{*}{$\begin{array}{c}\text { Porosity } \\
\text { (\%) }\end{array}$} & \\
\hline & & & GRAPE $^{a}$ & Syringe & & & & & & & \\
\hline 1 & 4 & & & 100 & Silty clay & & & 54.99 & 1.41 & 77.60 & \\
\hline & 5 & & & $144-150$ & Silty clay & & & 57.10 & 1.40 & 80.03 & \\
\hline 2 & 4 & 2.65 & A & 100 & Foram-rich silty clay & 1.54 & 73 & 50.49 & 1.46 & 73.63 & \\
\hline 3 & 4 & 2.65 & $\mathrm{~A}$ & & Silty clay & 1.53 & 73.5 & & & & \\
\hline \multirow[t]{2}{*}{4} & 4 & 2.65 & $0-60$ & & Foram-diatom-clay ooze & 1.50 & 75 & & & & \\
\hline & & 2.65 & $60-115$ & 115 & Silty clay & 1.55 & 72 & 53.66 & 1.40 & 74.97 & \\
\hline \multirow[t]{2}{*}{5} & 2 & 2.65 & $0-95$ & 67 & Silty clay & 1.48 & 77 & 44.21 & 1.58 & 69.83 & \\
\hline & & 2.65 & $95-150$ & & Foram-diatom silty clay & 1.52 & 74 & & & & \\
\hline 6 & 5 & 2.65 & A & 45 & Sandy silty clay & 1.54 & 73 & 42.76 & 1.58 & 67.49 & \\
\hline 7 & 3 & 2.65 & A & 111 & Silty clay & 1.53 & 73.5 & 49.30 & 1.46 & 71.94 & \\
\hline 8 & 3 & 2.65 & A & 127 & Silty clay & 1.53 & 73.5 & 50.44 & 1.46 & 73.86 & Volc. ash \\
\hline \multirow[t]{2}{*}{9} & 5 & 2.65 & $0-60$ & & Silty clay & 1.53 & 73.5 & & & & \\
\hline & & 2.65 & $60-150$ & & Silty sand & 1.76 & 58 & & & & \\
\hline \multirow[t]{3}{*}{10} & 4 & & & $144-150$ & Silty clay & & & 51.59 & 1.45 & 74.60 & \\
\hline & 5 & 2.65 & $0-75$ & & Sandy silty clay & 1.48 & 77 & & & & \\
\hline & & 2.65 & $75-150$ & 100 & Sandy silty clay & 1.60 & 68 & 48.95 & 1.47 & 72.10 & Less sandy \\
\hline 11 & 5 & 2.65 & A & & Silty clay & 1.48 & 77 & & & & \\
\hline \multirow{2}{*}{12} & 5 & 2.65 & $0-110$ & & Silty clay & 1.55 & 72 & & & & \\
\hline & & 2.65 & $110-150$ & & Sandy & 1.75 & 59 & & & & \\
\hline \multirow[t]{2}{*}{13} & 3 & 2.65 & A & & Clayey silt & 1.48 & 77 & & & & \\
\hline & 5 & 2.65 & A & & Silty clay & 1.50 & 75 & & & & \\
\hline 14 & 4 & 2.65 & $0-100$ & & Sandy silty clay & 1.55 & 72 & & & & \\
\hline & & 2.65 & $100-150$ & & Clayey silty sand & 1.69 & 63 & & & & \\
\hline 15 & 2 & 2.65 & A & & Clayey silt & 1.48 & 77 & & & & \\
\hline & 4 & & & $144-150$ & Clay & & & 39.16 & 1.63 & 63.69 & \\
\hline 16 & 3 & 2.65 & A & 15 & Silty clay & 1.61 & 68 & 41.37 & 1.55 & 64.26 & \\
\hline 17 & 2 & 2.65 & $0-40$ & & Sandy silty clay & 1.76 & 58 & & & & \\
\hline & & 2.65 & $60-100$ & & Silty clay & 1.61 & 68 & & & & \\
\hline & & 2.65 & $100-150$ & & Sandy silt & 1.80 & 56 & & & & \\
\hline 18 & 4 & 2.65 & $0-75$ & & Clay & 1.55 & 72 & & & - & \\
\hline & & 2.65 & $75-120$ & & Silty clay & 1.48 & 77 & & & & \\
\hline & & 2.65 & $120-150$ & & Sandy silty clay & 1.62 & 68 & & & & \\
\hline 19 & 5 & 2.65 & A & & Sandy silty clay & 1.73 & 60 & & & & \\
\hline 20 & 2 & 2.65 & $0-120$ & & Silty clay & 1.62 & 68 & & & & \\
\hline & & 2.65 & $120-150$ & $144-150$ & Sandy & 1.71 & 61 & 33.71 & 1.71 & 57.74 & \\
\hline 22 & 3 & 2.65 & A & & Silty clay & 1.54 & 73 & & & & \\
\hline & 4 & 2.65 & A & & Silty clay & 1.49 & 76 & & & & \\
\hline 29 & 1 & 2.65 & - & & Sandy silty clay & 1.60 & 68 & & & & \\
\hline 30 & 4 & 2.65 & A & $144-150$ & Silty clay & 1.60 & 68 & 38.75 & & & \\
\hline 31 & 2 & 2.65 & A & & Silty clay & 1.58 & 70 & & & & \\
\hline 32 & 1 & & & $144-150$ & Micarb-rich silty clay & & & 34.20 & & & \\
\hline & 2 & 2.65 & A & & Micarb-rich silty clay & 1.69 & 63 & & & & \\
\hline 33 & 2 & 2.65 & A & & Silty clay & 1.60 & 68 & & & & \\
\hline 35 & 2 & 2.65 & $0-70$ & & Silty clay & 1.53 & 73.5 & & & & \\
\hline 36 & 2 & & & $144-150$ & Slightly silty clay & & & 28.27 & & & \\
\hline & 4 & 2.65 & A & & Ash-rich silty clay & 1.84 & 53 & & & & Layered \\
\hline 37 & 2 & 2.65 & A & & Ash-rich silty clay & 1.82 & 54 & & & & Layered \\
\hline & 3 & 2.65 & A & & Ash-rich silty clay & 1.90 & 49 & & & & Layered \\
\hline
\end{tabular}

${ }^{\mathrm{a}} \mathrm{A}=$ average reading from the GRAPE analog record.

\section{Horizontal Versus Vertical Shear Strength}

Most vane-shear measurements were made on core faces, whereas a few were made on horizontal bedding surfaces. The shear-strength measurements taken in the vertical plane are generally higher than the adjacent horizontal determinations (see Figure 7 and Tables 7, $10,11,17$, and 20). This discrepancy can be accounted for by the fact that vertical measurements were taken across bedding anisotropy, but the horizontal measurements were made in the bedding plane which probably has a nearly isotropic fabric.

\section{Shear Strength Versus Lithology}

One of the most significant results of the shearstrength studies on Leg 31 was the opportunity to compare consistently determined strength profiles for a wide variety of deep-sea sediments. The enveloping curves of the uncorrected shear-strength data are summarized in Figure 20. In Figure 21 the various enveloping curves are identified by lithology: carbonate ooze (Site 299); pelagic brown clay (Site 294); diatom ooze (Site 302, lower portion); hemipelagic-terrigenous mud (average of Sites 297, 299, 302 [upper portion]). Results from Site 


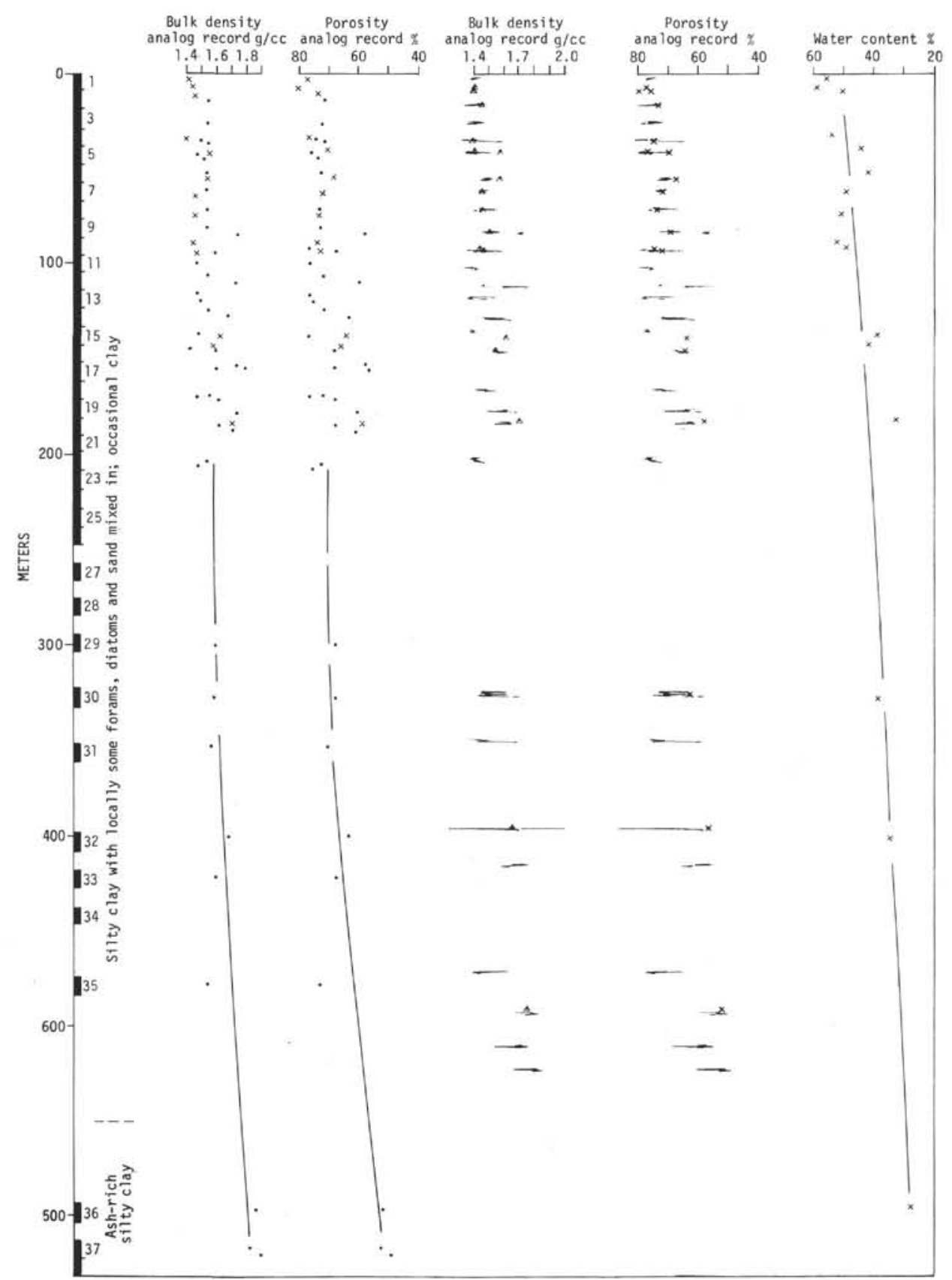

Figure 14. Plot of physical properties for Site 299. GRAPE analog record readings as well as computer plot are presented in addition to laboratory analyses (syringe and chunk methods). On the left the cores are given as black rectangles and the general lithology.

298 are not utilized in the following comparison since they show postdepositional structural disturbance.

In order to better compare shear strengths of various lithologies, the values and percentage differences for 50 and 100 meters have been compiled (Table 23). At 50 meters the pelagic brown clay is the weakest lithology, the hemipelagic-terrigenous mud is of medium strength and the carbonate ooze is by far the strongest. At 100 meters the relative differences in strength have markedly decreased. The carbonate ooze has the strongest lithology; the hemipelagic-terrigenous mud and brown pelagic clays are weaker, but of comparable strength; the diatom ooze is the weakest sediment at 100 meters.

The higher strength of the carbonate ooze is probably due to incipient cementation which would increase the cohesion of the sediment over and above that caused by compaction and dewatering. In support of this interpretation, Roth and Thierstein (1972) have noted slight degrees of secondary calcite overgrowth on particles in carbonate oozes buried approximately 100 meters. The weakness of diatomaceous deposits relative to clayey sediments has been previously noted in cores recovered 


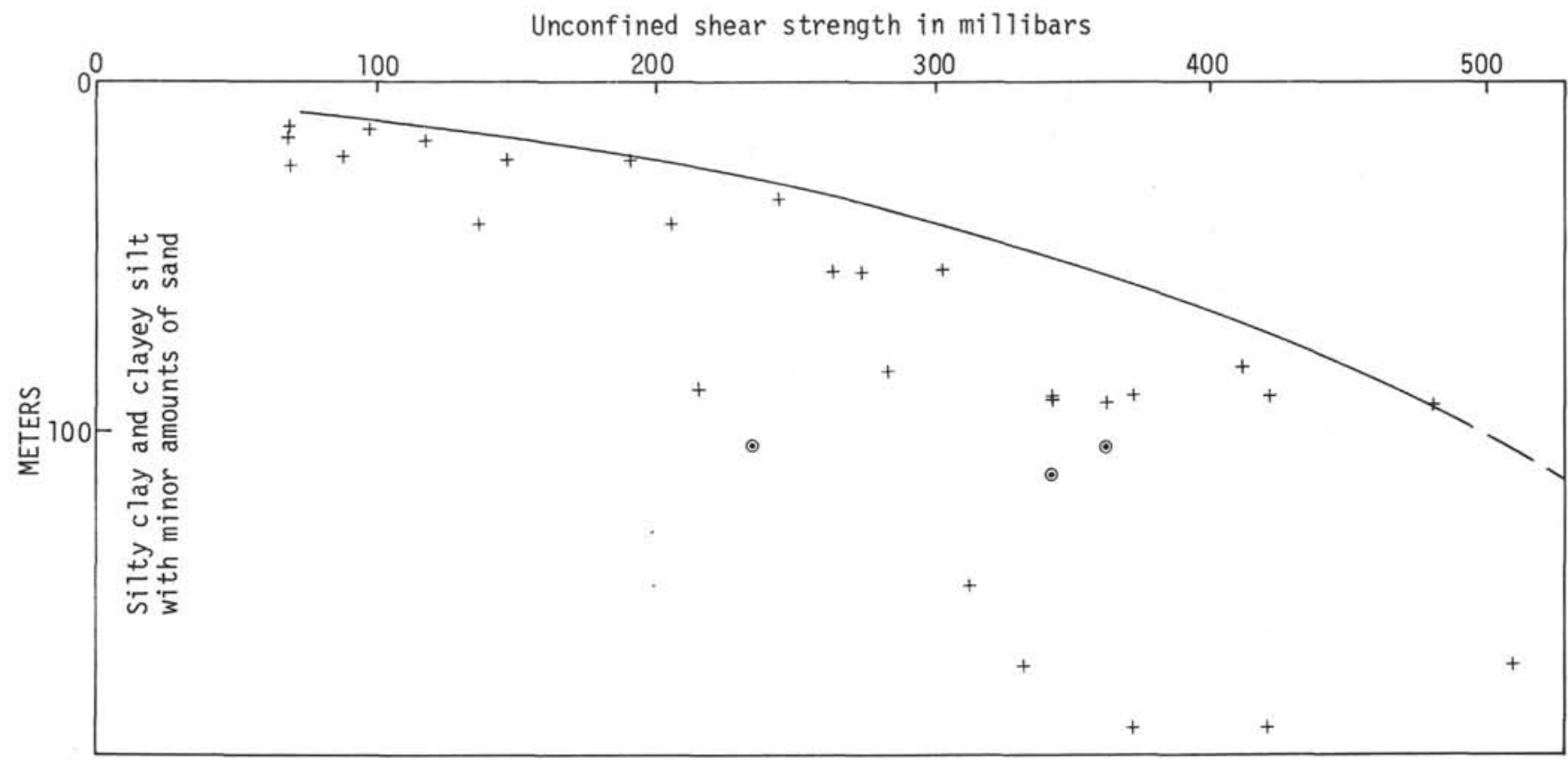

Figure 15. Plot of unconfined shear strength with depth, Site 299.

TABLE 19

Vane Shear Data, Site 299

\begin{tabular}{cccr}
\hline $\begin{array}{c}\text { Sample } \\
\text { (Interval in cm) }\end{array}$ & $\begin{array}{c}\text { Depth } \\
\text { (to nearest } \\
\text { half meter) }\end{array}$ & $\begin{array}{c}\text { Plane of } \\
\text { Measurement }\end{array}$ & $\begin{array}{c}\text { Shear } \\
\text { Strength } \\
\text { (mbar) }\end{array}$ \\
\hline $2-3,57$ & 15 & Vertical & 68.4 \\
$2-3,91$ & 15.5 & Vertical & 97.7 \\
$2-5,52$ & 18 & Vertical & 67.9 \\
$2-5,131$ & 19 & Vertical & 117.7 \\
$3-2,75$ & 25 & Vertical & 87.9 \\
$3-2,144$ & 25.5 & Vertical & 190.4 \\
$3-3,17$ & 25.5 & Vertical & 146.5 \\
$3-4,68$ & 27.5 & Vertical & 68.4 \\
$4-4,43$ & 37 & Vertical & 244.1 \\
$5-2,78$ & 42.5 & Vertical & 136.7 \\
$5-2,87$ & 42.5 & Vertical & 205.1 \\
$5-2,123$ & 43.0 & Vertical & 136.7 \\
$6-5,10$ & 55.5 & Vertical & 302.7 \\
$6-5,60$ & 56.0 & Vertical & 263.6 \\
$6-5,104$ & 56.5 & Vertical & 273.4 \\
$9-4,75$ & 83.5 & Vertical & 410.1 \\
$9-5,41$ & 89.5 & Vertical & 283.2 \\
$10-2,111$ & 90.0 & Vertical & 214.8 \\
$10-3,95$ & 91.5 & Vertical & 371.1 \\
$10-3,103$ & 91.5 & Vertical & 419.9 \\
$10-4,20$ & 92.0 & Vertical & 341.8 \\
$10-4,120$ & 93.0 & Vertical & 341.8 \\
$10-5,38$ & 94.0 & Vertical & 361.3 \\
$10-5,95$ & 94.5 & Vertical & 478.5 \\
11, CC & 104.5 & Horizontal & 234.4 \\
11, CC & 104.5 & Horizontal & 361.3 \\
12, CC & 114.0 & Horizontal & 341.8 \\
$16-2,10$ & 147.5 & Vertical & 312.5 \\
$18-4,30$ & 170.0 & Vertical & 507.8 \\
$18-4,97$ & 170.5 & Vertical & 332.0 \\
$20-3,108$ & 189.5 & Vertical & 419.9 \\
$20-3,112$ & 189.5 & Vertical & 371.1 \\
\hline & & & \\
& & & \\
\hline & & &
\end{tabular}

from the Bering Sea (Lee, 1973). Lee's consolidation experiments show that diatom oozes are markedly less compressible than clayey sediments at low to moderate stresses. Therefore, the relative increase in the number and extent of grain-to-grain contacts is less within a diatom ooze than in clayey sediment and the cohesion (shear strength) of the diatom ooze increases slowly during shallow burial.

The convergence in shear strength between the pelagic brown clay and hemipelagic-terrigenous mud may be due to the rapid decrease in water content (and porosity) of former lithology. For example, the water content of the pelagic brown clay (Site 294) decreases from $71 \%$ to $51 \%$ over the interval from 50 to 100 meters whereas the water content of the hemipelagic-terrigenous mud (average of Sites 297 and 299) drops only from $47 \%$ to $43.5 \%$ over the same interval. The initial high water content of the pelagic brown clay is undoubtedly due to its fine uniform grain size.

These physical or geotechnical properties, except the vane shear, are measured as a routine precedure onboard Glomar Challenger. However, on most legs no experts are present and the sedimentologist(s) and/or geophysicist(s) have to take responsibility for this aspect of the program in addition to his normal duties. As a result, the data from many legs are not comparable and the field of marine geotechnique, which is still in its infant stage, suffers from this great opportunity the Deep Sea Drilling Program can offer.

\section{RECOMMENDATIONS}

The routine of the GRAPE measurements should be changed. The marine technicians are instructed to 
TABLE 20

Bulk Density, Porosity, and Water Content as Determined by the GRAPE and Syringe Methods, Site 301

\begin{tabular}{|c|c|c|c|c|c|c|c|c|c|c|c|}
\hline \multirow[b]{3}{*}{ Core } & \multirow[b]{3}{*}{ Section } & \multirow{3}{*}{$\begin{array}{l}\text { Diameter } \\
\text { (in.) }\end{array}$} & \multirow{2}{*}{\multicolumn{2}{|c|}{ Interval $(\mathrm{cm})$}} & \multirow[b]{3}{*}{ Lithology } & \multicolumn{2}{|c|}{ GRAPE } & \multicolumn{3}{|c|}{ Syringe } & \multirow[b]{3}{*}{ Remarks } \\
\hline & & & & & & \multirow{2}{*}{$\begin{array}{c}\text { Bulk } \\
\text { Density } \\
(\mathrm{g} / \mathrm{cc})\end{array}$} & \multirow{2}{*}{$\begin{array}{l}\text { Porosity } \\
\text { (\%) }\end{array}$} & \multirow{2}{*}{$\begin{array}{c}\text { Water } \\
\text { Content } \\
(\%)\end{array}$} & \multirow{2}{*}{$\begin{array}{c}\text { Bulk } \\
\text { Density } \\
(\mathrm{g} / \mathrm{cc})\end{array}$} & \multirow{2}{*}{$\begin{array}{l}\text { Porosity } \\
(\%)\end{array}$} & \\
\hline & & & GRAPE $^{a}$ & Syringe & & & & & & & \\
\hline \multirow[t]{5}{*}{2} & 2 & 2.65 & $0-130$ & & Silty clay & 1.46 & 78 & \multirow{8}{*}{51.12} & \multirow{8}{*}{1.45} & \multirow{7}{*}{74.09} & \\
\hline & & 2.65 & $130-150$ & & Sandy silty clay & 1.53 & 73 & & & & \\
\hline & 3 & & & $144-150$ & Silty clay & & & & & & \\
\hline & 4 & 2.65 & $0-100$ & & Silty clay & 1.45 & 79 & & & & \\
\hline & & 2.65 & $100-150$ & & Silty clay with ash & 1.52 & 74 & & & & \\
\hline \multirow[t]{3}{*}{3} & 2 & 2.65 & $0-50$ & & Silty clay & 1.51 & 74.7 & & & & Gas voids \\
\hline & & 2.65 & $50-120$ & & Sand & 1.60 & 69 & & & & \\
\hline & & 2.65 & $120-150$ & & Silty clay & 1.51 & 74.7 & & & \multirow{4}{*}{35.23} & Gas voids \\
\hline \multirow{3}{*}{$\begin{array}{l}4 \\
5\end{array}$} & 3 & & & $144-150$ & Sandy silty clay & & & \multirow[t]{3}{*}{20.62} & \multirow[t]{3}{*}{1.71} & & \\
\hline & 6 & 2.65 & $30-100$ & & Clay & 1.70 & 62 & & & & Gas voids \\
\hline & & 2.65 & $100-150$ & & Clay & 1.75 & 59 & & & & Gas voids \\
\hline 8 & 2 & & & $144-150$ & Clayey diatom ooze & & & 48.17 & 1.45 & 69.89 & \\
\hline 11 & 1 & & & $144-150$ & Clayey diatomite & & & 41.29 & 1.53 & 63.10 & Chunk method \\
\hline \multirow[t]{3}{*}{15} & 3 & & & $144-150$ & Clayey diatomite & & & 45.67 & 1.49 & 67.94 & Samll gas voids \\
\hline & 4 & 2.65 & $0-45$ & & Clayey diatomite & 1.52 & 74 & & & & Gas voids \\
\hline & & 2.65 & $95-150$ & & Clayey diatomite & 1.60 & 69 & & & & Gas voids \\
\hline \multirow[t]{5}{*}{18} & 2 & 2.65 & $0-95$ & & Clay & 1.58 & 70 & & & & Gas voids \\
\hline & & 2.65 & $95-130$ & & Sandy silty clay & 1.70 & 62 & & & & Gas voids \\
\hline & 3 & & & $\begin{array}{l}144-150 \\
144-150\end{array}$ & $\begin{array}{l}\text { Clay } \\
\text { Clay }\end{array}$ & & & $\begin{array}{l}47.92 \\
25.45\end{array}$ & 1.37 & 65.80 & $\mathrm{a}$ \\
\hline & & & & $144-150$ & Clay & & & 25.73 & 1.83 & 47.06 & Chunk method ${ }^{a}$ \\
\hline & 4 & 2.65 & AI & & Diatomaceous claystone & 1.65 & 66 & & & & Gas voids \\
\hline \multirow[t]{2}{*}{19} & 5 & 2.65 & $0-50$ & & Micarb claystone & 1.54 & 73 & & & & Gas voids \\
\hline & & 2.65 & $100-150$ & & Micarb claystone & 1.60 & 69 & & & & Gas voids \\
\hline \multirow[t]{4}{*}{20} & 3 & 2.65 & $0-60$ & & Diatomaceous claystone & 1.65 & 66 & & & & Gas voids \\
\hline & & 2.65 & $70-130$ & & Diatomaceous claystone & 1.60 & 69 & & & & Gas voids \\
\hline & 4 & & $144-150$ & & Diatomaceous claystone & & & 39.71 & 1.55 & 61.49 & a \\
\hline & & & $\begin{array}{l}144-150 \\
144-150\end{array}$ & & $\begin{array}{l}\text { Diatomaceous claystone } \\
\text { Diatomaceous claystone }\end{array}$ & & & $\begin{array}{l}37.00 \\
37.98\end{array}$ & 1.61 & 61.01 & $\begin{array}{l}\mathrm{b} \\
\text { Chunk method }\end{array}$ \\
\hline
\end{tabular}

Note: Most analog records have irregular curves due to gas voids. AI = average reading of a very irregular GRAPE analog record.

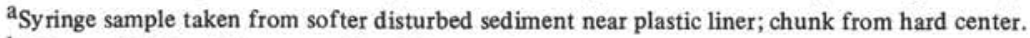

byolume slightly off due to small voids in sample.

measure at least two sections per core, normally the numbers 2 and 5 . Little attention is paid to the degree of visible disturbance of the uncut core. The scientists in charge should select which sections are to be measured, preferably at least always the lowest section. In addition to disturbance, measurements should be done on the diameter of each measured section and the thickness of the liner. Too often this diameter is assumed to be 2.60 in. $(6.6 \mathrm{~cm})$ for normal cores and 2.25 in. $(5.71 \mathrm{~cm})$ for punch cores. It is recommended to measure less core sections and to spend more time on each measurement. The scientist in charge should have a good updated set of instructions available instead of sets of instructions of different dates. He should make a list of each section measured with regard to dimensions, lithology, filling of the liner, and degree of distortion. Also some quantitative notes about each analog record should be made. This scientist also should select the location for taking cylinder samples and larger syringe samples.

Utilization of the "Torvane" appparatus on Leg 31 has shown that it is a viable instrument for rapid determination of unconfined shear strength on split core faces. In addition to estimates of consolidation and lithification, vane-shear measurements provide a rapid means of quantitatively estimating core disturbance within a given lithology. In view of the small variation of vane-shear strength values between lithologies, routine collection of vane-shear data on successive DSDP cruises is recommended. It is expected that consistent patterns in shear strength for a given lithology will emerge.

\section{ACKNOWLEDGMENTS}

The authors are thankful to all their colleagues, technical and clerical personnel who were onboard Glomar Challenger during Leg 31 for their help in collecting these data. Specific thanks go to Stan M. White for his encouragement to carry out this particular study.

Bruce R. Sidner critically read the manuscript and Mrs. Margie L. Dupler did all the final typing. Mark Bouma assisted in the plotting of the graphs. Their help is greatly appreciated.

Acknowledgment is made to the donors of the Petroleum Research Fund, American Chemical Society (Grant No. 248363) for partial support of this work at the University of California, Santa Cruz.

\section{REFERENCES}

Bennett, R.H. and Keller, G.H., 1973. Physical properties evaluation. I $n$ van Andel, T.H., Heath, G.R., et al., Initial Reports of the Deep Sea Drilling Project, Volume 16: Washington (U.S. Government Printing Office), p. 513-519.

Boyce, R.E., 1972a. Syringe technique and rock chunk technique. Porosity, wet-bulk density and water content: Unpublished report, June 15, Deep Sea Drilling Project.

1972b. Cylinder technique: porosity, water content and wet-bulk density: Unpublished report, June 15, Deep Sea Drilling Project. 


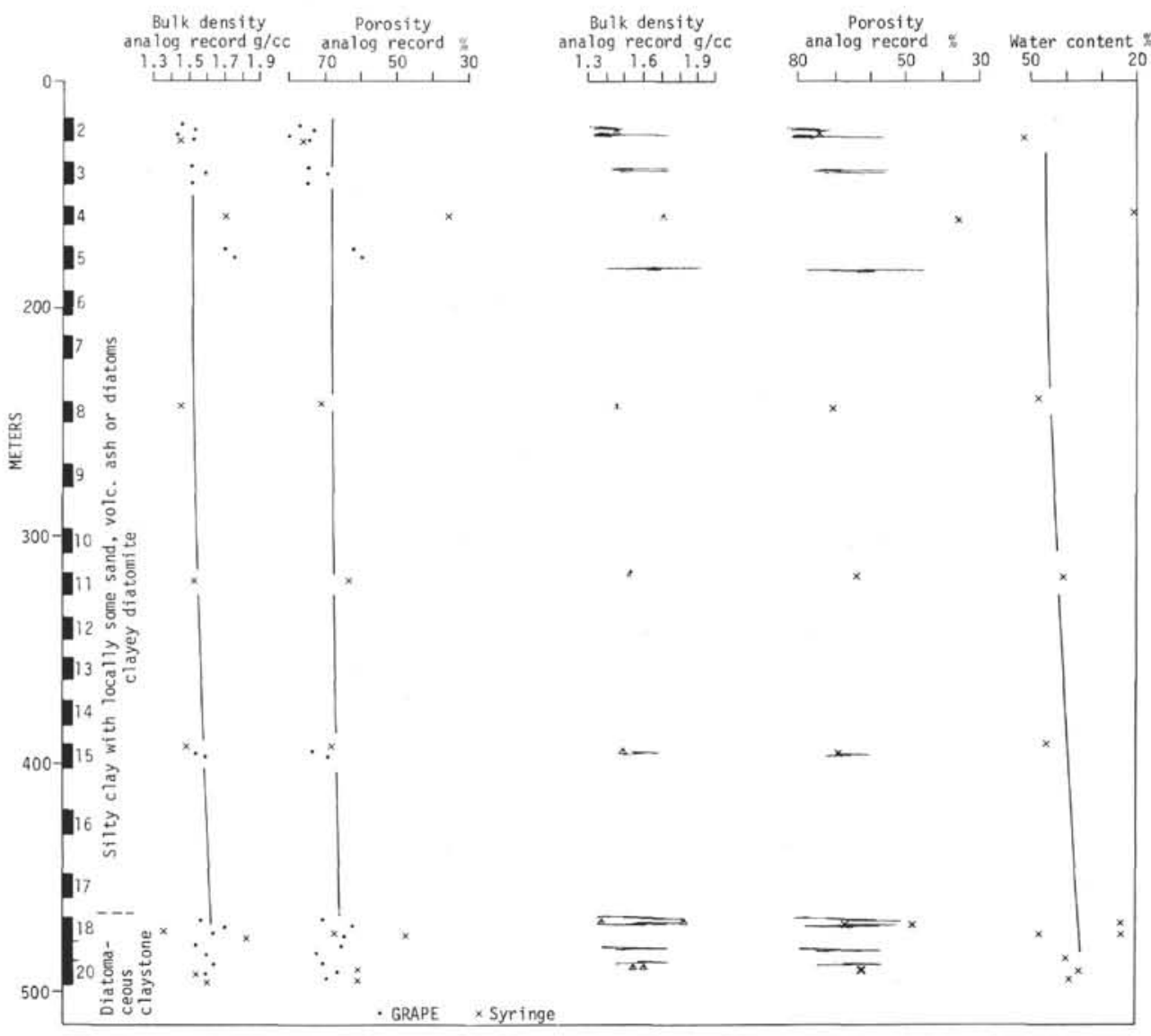

Figure 16. Plot of physical properties for Site 301. GRAPE analog record readings as well as computer plot are presented in addition to laboratory analyses (syringe and chunk methods). On the left the cores are given as black rectangles and the general lithology.

1972c. GRAPE. Memorandum to shipboard scientists responsible for physical properties aboard the Glomar Challenger: Unpublished report, October 12, 1972, Deep Sea Drilling Project.

1973a. Cylinder technique, attenuation coefficients, porosity, water content and wet-bulk density: Unpublished report, revised 20 April 1973, Deep Sea Drilling Project. 1973b. Discrete sampling technique, definitions and equations: Unpublished report, Deep Sea Drilling Project. 1973c. Physical properties-methods. In Edgar, N.T., Saunders, J.B., et al., Initial Reports of the Deep Sea Drilling Project, Volume 15: Washington (U.S. Government Printing Office), p. 1115-1127.

1973d. Renovated GRAPE and POROSITYDENSITY Program: Memorandum, Deep Sea Drilling Project (to N.T. Edgar), January 11.

$1973 \mathrm{e}$. Wet-bulk density determination of marine sediments by gamma ray attenuation: derivation of the techniques and its use for data collected during Legs 3 through 11 of the Deep Sea Drilling Project: Unpublished Manuscript, Deep Sea Drilling Project.

1974a. Instructions for grain density, wet-bulk density, water content and porosity determinations by individual samples and gamma ray attenuation porosity evaluator: Unpublished report, January 18, 1973, revised January 16, 1974, Deep Sea Drilling Project.

1974b. Diameter problems in 2-minute count GRAPE data: Memorandum to shipboard scientists and technicians. June 3, 1974. Deep Sea Drilling Project.
Cernock, P.J., 1970. Sound velocities in Gulf of Mexico sediments as related to physical properties and simulated overburden pressures: Tech. Rept., Texas A\&M Univ., Res. Found., ref. 70-5-T.

Evans, H.B., 1965. GRAPE-A device for continuous determination of material density and porosity. SPWLA Logging Symp., 6th Ann., Dallas, Texas, 1965, Trans., v. 2, p. B1-25.

Gealy, E.L., 1971. Saturated bulk density, grain density and porosity of sediment cores from the western equatorial Pacific: Leg 7, Glomar Challenger. In Winterer, E.L., et al., Initial Reports of the Deep Sea Drilling Project, Volume 7: Washington (U.S. Government Printing Office), p. 1081-1104.

Harms, J.C. and Choquette, P.W., 1965. Geologic evaluation of a gamma-ray porosity device. SPWLA Logging Symp., 6th Ann., Dallas, Texas, 1965, Trans., v. 2, p. C1-37.

Lee, H.J., 1973. Measurements and estimates of engineering and other physical properties, Leg 19. In Creager, J.S., Scholle, D.W., et al., Initial Reports of the Deep Sea Drilling Project, Volume 19: Washington (U.S. Government Printing Office), p. 701-719.

Manheim, F.T., Dwight, L., and Belastock, R.A., 1974. Porosity, density, grain density and related physical properties of sediments from the Red Sea drill cores. In Whitmarsh, R.B., Weser, O.E., Ross, D.A., et al., Initial Reports of the Deep Sea Drilling Project, Volume 23: Washington (U.S. Government Printing Office), p. 887-907. 
TABLE 21

Bulk Density, Porosity, and Water Content as Determined by the GRAPE and Syringe Methods, Site 302

\begin{tabular}{|c|c|c|c|c|c|c|c|c|c|c|c|}
\hline \multirow[b]{3}{*}{ Core } & \multirow[b]{3}{*}{ Section } & \multirow{3}{*}{$\begin{array}{l}\text { Diameter } \\
\text { (in.) }\end{array}$} & \multirow{2}{*}{\multicolumn{2}{|c|}{ Interval $(\mathrm{cm})$}} & \multirow[b]{3}{*}{ Lithology } & \multicolumn{2}{|c|}{ GRAPE } & \multicolumn{3}{|c|}{ Syringe } & \multirow[b]{3}{*}{ Remarks } \\
\hline & & & & & & \multirow{2}{*}{$\begin{array}{c}\text { Bulk } \\
\text { Density } \\
(\mathrm{g} / \mathrm{cc})\end{array}$} & \multirow{2}{*}{$\begin{array}{c}\text { Porosity } \\
(\%)\end{array}$} & \multirow{2}{*}{$\begin{array}{c}\text { Water } \\
\text { Content } \\
(\%)\end{array}$} & \multirow{2}{*}{$\begin{array}{c}\text { Bulk } \\
\text { Density } \\
(\mathrm{g} / \mathrm{cc})\end{array}$} & \multirow{2}{*}{$\begin{array}{c}\text { Porosity } \\
(\%)\end{array}$} & \\
\hline & & & GRAPE $^{\mathrm{a}}$ & Syringe & & & & & & & \\
\hline \multirow[t]{6}{*}{2} & 2 & 2.65 & A & 35 & Diatom-rich silty clay & 1.45 & 79 & 59.18 & 1.33 & 78.66 & \\
\hline & 5 & & & 130 & Diatom-rich silty clay & & & 48.24 & 1.46 & 70.63 & \\
\hline & & & & $144-150$ & Diatom-rich silty clay & & & 44.58 & 1.52 & 67.97 & \\
\hline & 6 & 2.65 & $0-40$ & & Diatom-rich silty clay & 1.46 & 78 & & & & \\
\hline & & 2.65 & $67-120$ & & Diatom-rich silty clay & 1.33 & 87 & & & & Also volc. ash \\
\hline & & 2.65 & $120-150$ & & Diatom-rich silty clay & 1.46 & 78 & & & & \\
\hline \multirow[t]{4}{*}{3} & 2 & 2.65 & $0-60$ & & Zeolite-rich clay & 1.55 & 72 & & & & \\
\hline & & 2.65 & $60-120$ & 72 & Rad zeolite-rich clay & 1.46 & 78 & 54.19 & 1.40 & 79.06 & \\
\hline & & 2.65 & $120-150$ & & Zeolite-rich clay & 1.55 & 72 & & & & \\
\hline & 5 & 2.65 & A & 75 & Micarb zeolite-rich clay & 1.51 & 75 & 49.38 & 1.50 & 74.20 & \\
\hline \multirow[t]{4}{*}{4} & 3 & 2.65 & $0-75$ & 55 & Zeolite clay & 1.56 & 71 & 48.19 & 1.49 & 71.86 & \\
\hline & & 2.65 & $75-100$ & & Zeolite clay & 1.50 & 75 & & & & \\
\hline & 5 & 2.65 & $0-75$ & & Zeolite clay & 1.55 & 72 & & & & \\
\hline & & 2.65 & $75-150$ & & Zeolite clay & 1.50 & 75 & & & & \\
\hline \multirow[t]{5}{*}{5} & 2 & 2.65 & A & & Diatom ooze & 1.46 & 78 & & & & \\
\hline & 4 & & & $144-150$ & Diatom ooze & & & 57.71 & 1.36 & 78.29 & \\
\hline & 5 & 2.65 & $0-62$ & & Diatom ooze & 1.47 & 77 & & & & \\
\hline & & 2.65 & $62-96$ & & Diatom ooze & 1.35 & 85 & & & & \\
\hline & & 2.65 & $96-150$ & & Diatom ooze & 1.47 & 77 & & & & \\
\hline \multirow[t]{2}{*}{7} & 2 & 2.65 & A & 70 & Diatom ooze & 1.41 & 81 & 57.44 & 1.32 & 75.97 & \\
\hline & 5 & 2.65 & A & 75 & Diatom ooze & 1.42 & 81 & 55.90 & 1.37 & 76.70 & \\
\hline \multirow[t]{3}{*}{8} & 2 & 2.65 & A & 75 & Diatom ooze & 1.34 & 86 & 62.94 & 1.28 & 80.34 & \\
\hline & 4 & 2.65 & A & 75 & Diatom ooze & 1.36 & 85 & 60.38 & 1.31 & 79.09 & \\
\hline & 5 & & & $144-150$ & Diatom ooze & & & 60.86 & 1.26 & 76.71 & \\
\hline 9 & 2 & 2.65 & A & 75 & Diatom ooze & 1.34 & 86 & 62.95 & 1.28 & 80.57 & \\
\hline \multirow[t]{2}{*}{10} & 3 & 2.65 & A & 50 & Diatom ooze & 1.38 & 83 & 60.11 & 1.33 & 79.77 & \\
\hline & 6 & 2.65 & $\mathrm{~A}$ & 75 & Diatom ooze & 1.38 & 83 & 57.86 & 1.34 & 77.71 & \\
\hline \multirow[t]{2}{*}{11} & 4 & 2.65 & A & $144-150$ & Diatom ooze & 1.37 & 84 & 61.91 & 1.30 & 80.74 & \\
\hline & 5 & 2.65 & $\mathrm{~A}$ & 75 & Diatom ooze & 1.37 & 84 & 61.27 & 1.28 & 78.51 & \\
\hline 12 & 4 & 2.65 & A & 75 & Diatom ooze & 1.41 & 81 & 57.49 & 1.31 & 75.13 & \\
\hline 13 & 2 & 2.65 & $\mathrm{~A}$ & 75 & Diatom ooze & 1.42 & 81 & 55.48 & 1.36 & 75.43 & \\
\hline \multirow[t]{3}{*}{14} & 2 & 2.65 & A & 75 & Diatom ooze & 1.37 & 84 & 58.37 & 1.31 & 76.43 & \\
\hline & 4 & & & $144-150$ & Diatom ooze & & & 57.95 & 1.34 & 77.68 & \\
\hline & 5 & 2.65 & A & 75 & Diatom ooze & 1.37 & 84 & 57.12 & 1.32 & 76.46 & \\
\hline \multirow[t]{3}{*}{17} & 1 & & & $144-150$ & Zeolite-rich clay & & & 38.38 & 1.57 & 60.11 & Chunk method \\
\hline & 2 & 2.35 & piece & & Zeolite-rich clay & 1.37 & 84 & & & & \\
\hline & & 2.37 & piece & & Zeolite-rich clay & 1.35 & 85 & & & & \\
\hline
\end{tabular}

${ }^{\mathrm{a}} \mathrm{A}=$ average reading from the GRAPE analog record.

Roth, P.H. and Thierstein, H., 1972. Calcareous nannoplankton. In Hayes, D.E., Pimm, A.C., et al., Initial Reports of the Deep Sea Drilling Project, Volume 14: Washington (U.S. Government Printing Office), p. 421-481.
Schlumberger, 1966. The formation Density Log. In Schlumberger log interpretation principles. Paris (KecranServant (23827)), p. 47-49. 
A. H. BOUMA, J. C. MOORE

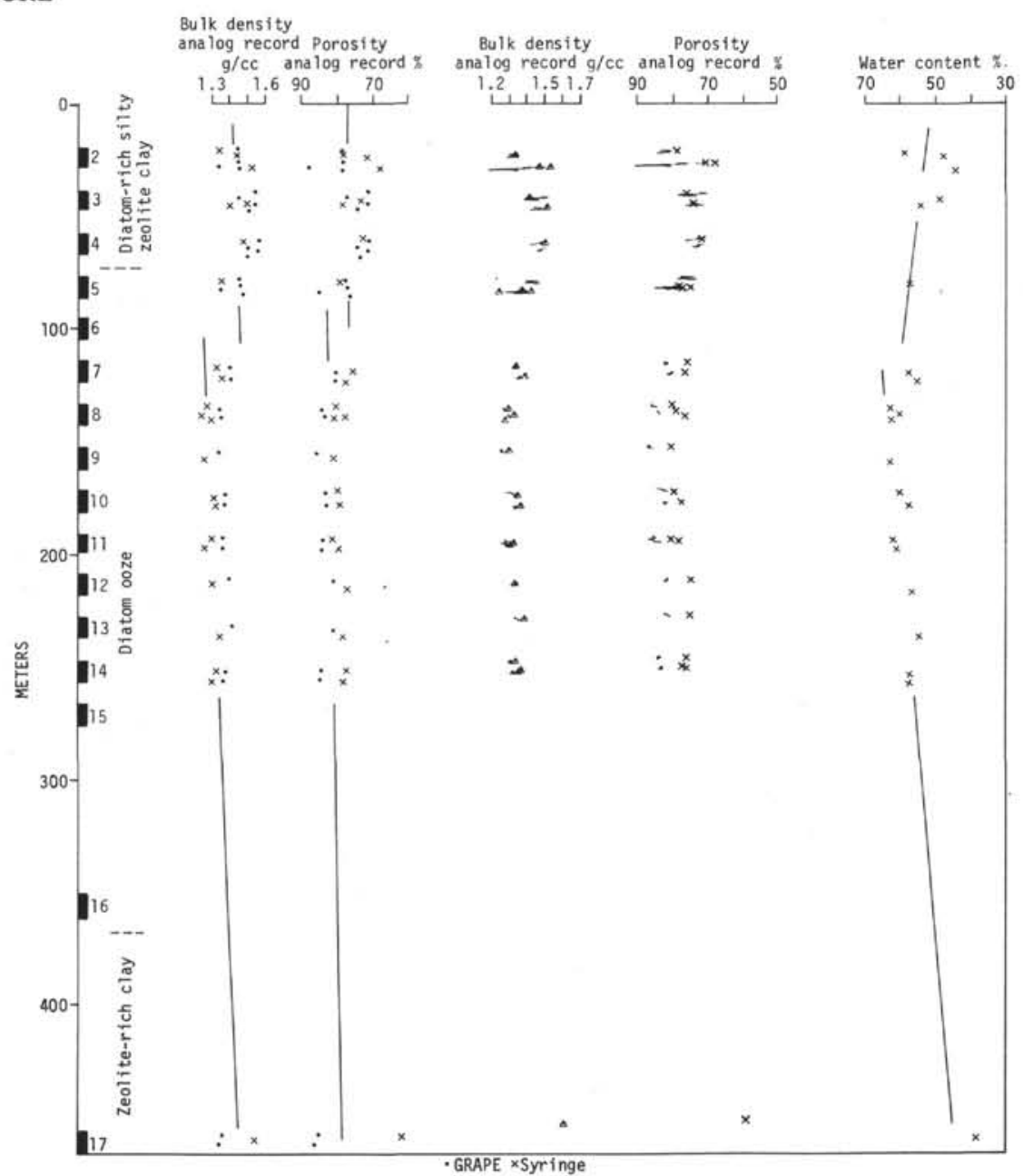

Figure 17. Plot of physical properties for Site 302. GRAPE analog record readings as well as computer plot are presented in addition to laboratory analyses (syringe and chunk methods). On the left the cores are given as black rectangles and the general lithology.

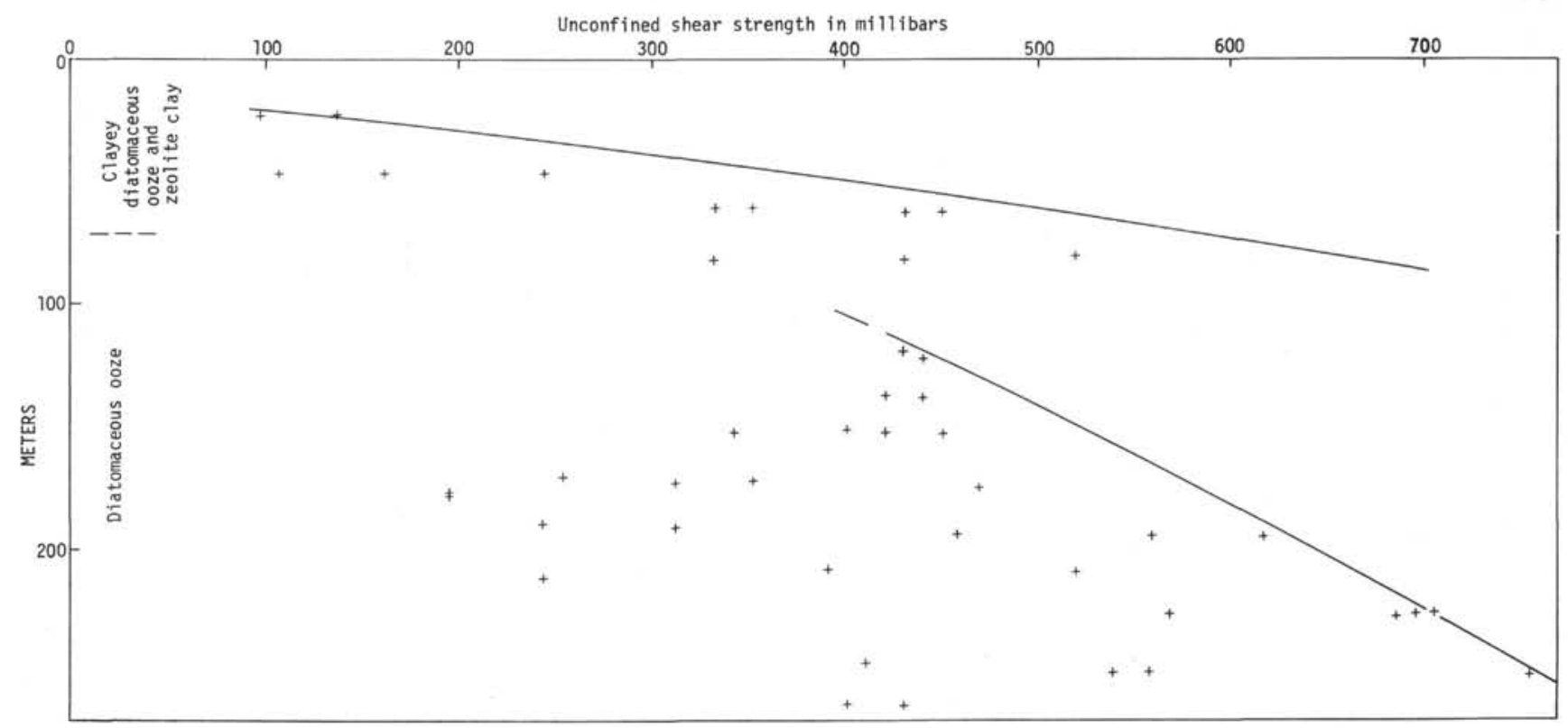

Figure 18. Plot of unconfined shear strength with depth, Site 302. 
TABLE 22

Vane Shear Data, Site 302

\begin{tabular}{|c|c|c|c|}
\hline $\begin{array}{c}\text { Sample } \\
\text { (Interval in } \mathrm{cm} \text { ) }\end{array}$ & $\begin{array}{c}\text { Depth } \\
\text { (to nearest } \\
\text { half meter) }\end{array}$ & $\begin{array}{c}\text { Plane of } \\
\text { Measurement }\end{array}$ & $\begin{array}{l}\text { Shear } \\
\text { Strength } \\
\text { (mbar) }\end{array}$ \\
\hline $2-4,10$ & 24.0 & Vertical & 97.6 \\
\hline $2-3,140$ & 24.0 & Vertical & 136.6 \\
\hline $3-6,100$ & 47.0 & Vertical & 162.0 \\
\hline $3-6,50$ & 46.5 & Vertical & 244.0 \\
\hline $3-6,145$ & 47.5 & Vertical & 107.4 \\
\hline $4-3,100$ & 63.0 & Vertical & 351.4 \\
\hline $4-3,135$ & 63.5 & Vertical & 331.8 \\
\hline $4-4,140$ & 65.0 & Vertical & 429.4 \\
\hline $4-4,135$ & 65.0 & Vertical & 448.9 \\
\hline $5-3,145$ & 82.5 & Vertical & 517.3 \\
\hline $5-4,145$ & 84.0 & Vertical & 429.4 \\
\hline $5-5,100$ & 85.0 & Vertical & 331.8 \\
\hline $5-5,120$ & 85.0 & Vertical & 683.2 \\
\hline $7-4,140$ & 120.5 & Vertical & 429.4 \\
\hline $7-6,140$ & 123.5 & Vertical & 439.2 \\
\hline $8-4,26$ & 138.0 & Vertical & 419.7 \\
\hline $8-4,106$ & 139.0 & Vertical & 439.2 \\
\hline $9-1,86$ & 159.5 & Vertical & 400.2 \\
\hline $9-1,135$ & 160.0 & Vertical & 419.7 \\
\hline $9-2,22$ & 160.0 & Vertical & 341.6 \\
\hline $9-2,111$ & 161.0 & Vertical & 448.9 \\
\hline $10-1,87$ & 172.5 & Vertical & 253.8 \\
\hline $10-2,87$ & 174.0 & Vertical & 351.8 \\
\hline $10-3,56$ & 175.0 & Vertical & 312.3 \\
\hline $10-4,87$ & 177.0 & Vertical & 468.0 \\
\hline $10-5,92$ & 178.5 & Vertical & 195.2 \\
\hline $10-6,76$ & 180.0 & Vertical & 195.2 \\
\hline $11-2,72$ & 194.0 & Vertical & 244.0 \\
\hline $11-3,74$ & 195.5 & Vertical & 312.3 \\
\hline $11-5,20$ & 198.0 & Vertical & 456.7 \\
\hline $11-5,75$ & 199.0 & Vertical & 556.3 \\
\hline $11-5,121$ & 199.0 & Vertical & 614.8 \\
\hline $12-2,42$ & 214.5 & Vertical & 390.4 \\
\hline $12-3,42$ & 216.0 & Vertical & 517.3 \\
\hline $12-4,37$ & 217.5 & Vertical & 244.0 \\
\hline $12-4,115$ & 218.0 & Vertical & 244.0 \\
\hline $13-1,83$ & 235.5 & Vertical & 702.7 \\
\hline $13-1,136$ & 236.0 & Vertical & 566.1 \\
\hline $13-2,30$ & 236.5 & Vertical & 693.0 \\
\hline $13-2,108$ & 237.0 & Vertical & 683.2 \\
\hline $14-2,89$ & 251.5 & Vertical & 409.9 \\
\hline $14-5,17$ & 255.0 & Vertical & 556.3 \\
\hline $14-5,65$ & 255.5 & Vertical & 536.8 \\
\hline $14-5,127$ & 256.5 & Vertical & 751.5 \\
\hline $15-1,70$ & 274.5 & Vertical & 400.2 \\
\hline $15-1,124$ & 275.0 & Vertical & 429.4 \\
\hline $16-1,140$ & 361.0 & Vertical & 927.2 \\
\hline
\end{tabular}

Bulk density

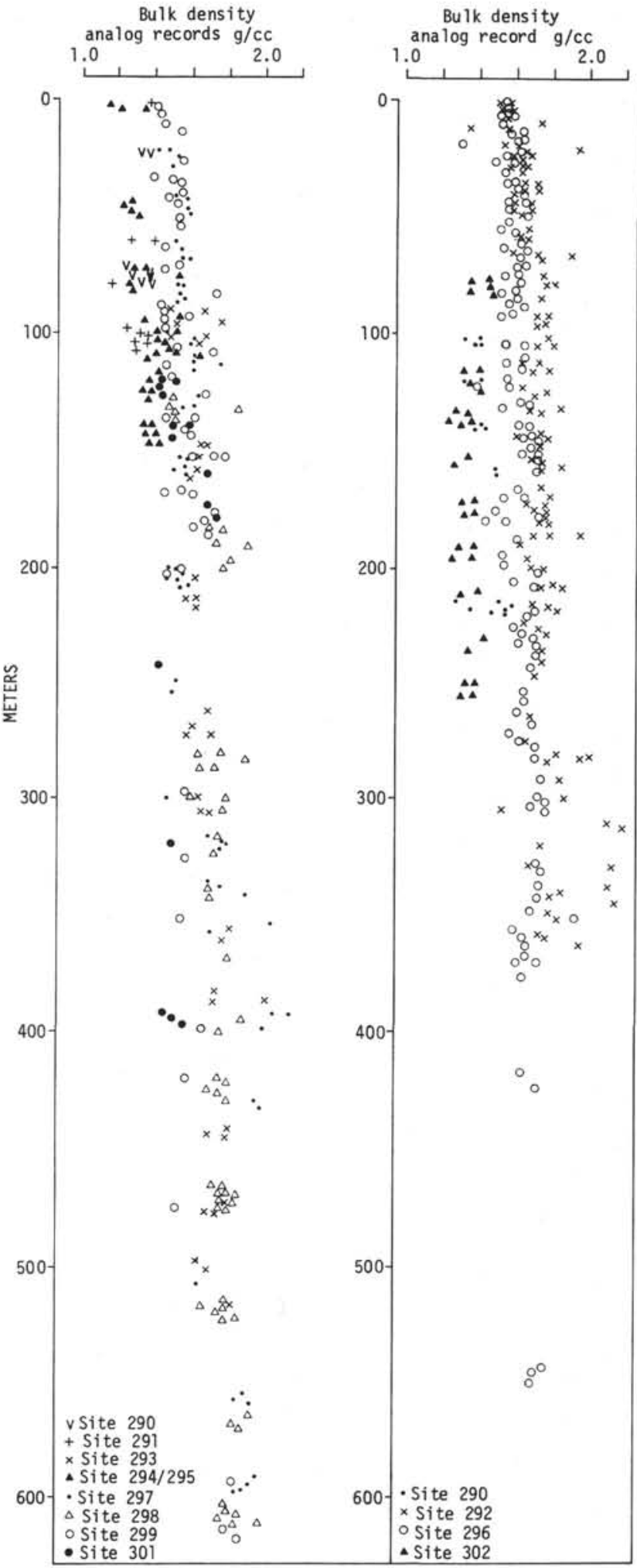

Figure 19. Plots of bulk densities obtained from GRAPE analog records for all sites of Leg 31, grouped according to major lithologies. For explanation, see text. 


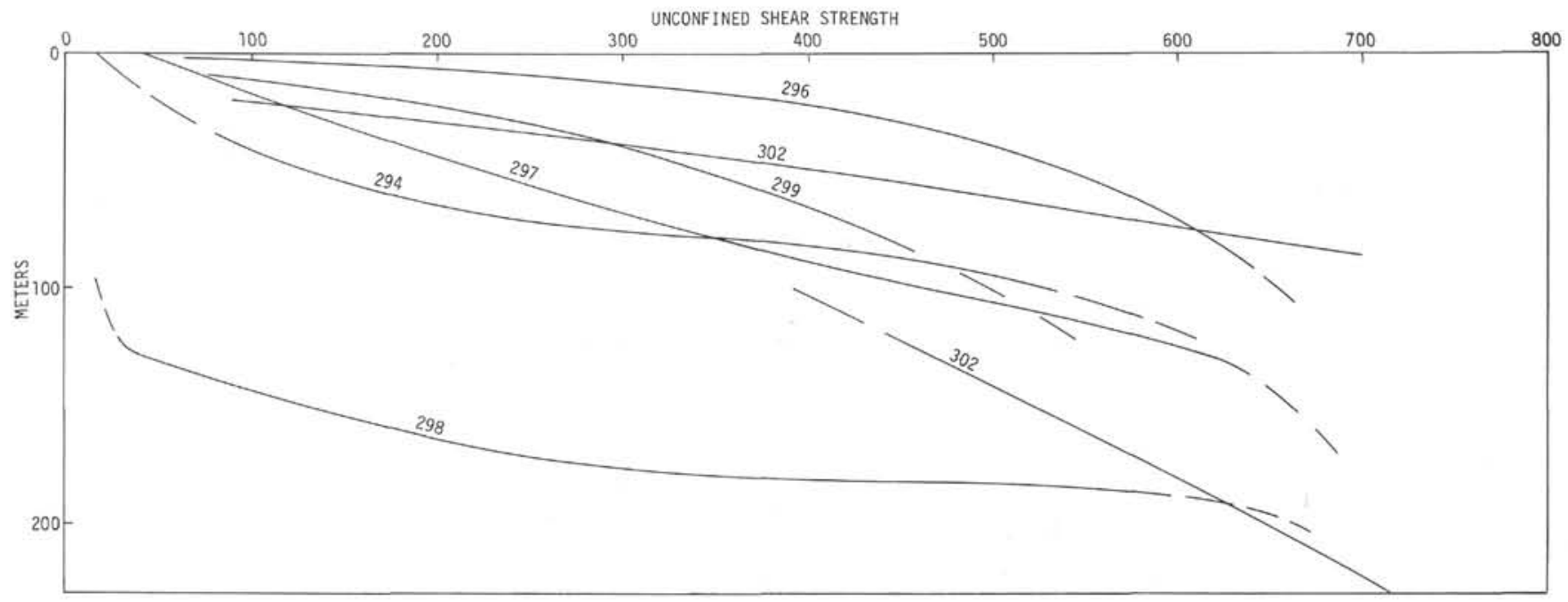

Figure 20. Summary of enveloping curves for all shear strength data for Leg 31.

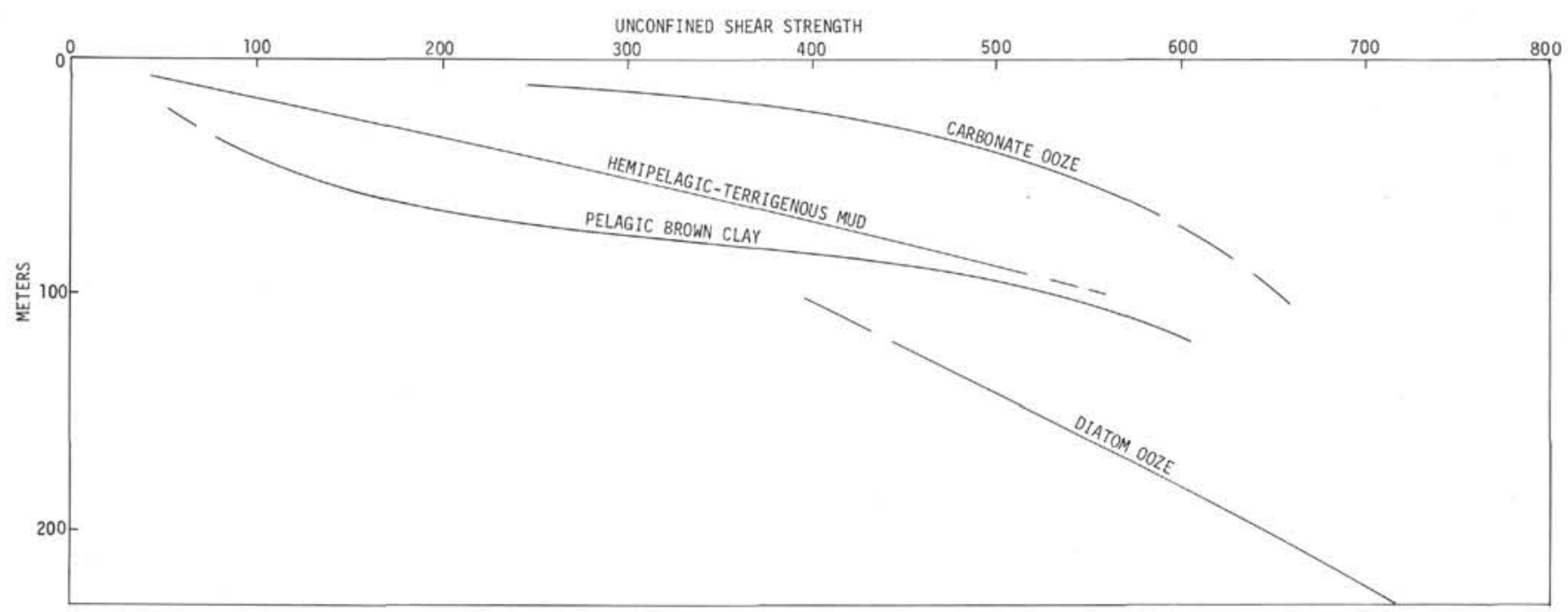

Figure 21. Summary of enveloping curves for shear strength characterized by homogeneous lithology. Carbonate ooze (Site 296), hemipelagic-terrigenous mud (average Sites 297, 299, 302-upper portion), pelagic brown mud (Site 294), diatom ooze (Site 302-lower portion).

TABLE 23

Shear Strength of Diatom Ooze, Pelagic Brown

Clay, Hemipelagic-Terrigenous Mud, and Carbonate Ooze

\begin{tabular}{ccccc}
\hline $\begin{array}{c}\text { Depth } \\
(\mathrm{m})\end{array}$ & $\begin{array}{c}\text { Diatom } \\
\text { Ooze }\end{array}$ & $\begin{array}{c}\text { Pelagic } \\
\text { Brown Clay }\end{array}$ & $\begin{array}{c}\text { Hemipelagic- } \\
\text { terrigenous } \\
\text { Mud }\end{array}$ & $\begin{array}{c}\text { Carbonate } \\
\text { Ooze }\end{array}$ \\
\hline \multirow{2}{*}{50} & - & 125 & 300 & 538 \\
& - & 0 & 140 & 330 \\
100 & 390 & 535 & 560 & 650 \\
& 0 & 37 & 44 & 67 \\
\hline
\end{tabular}

Note: Absolute strength indicated in mbar. Shear strength of lithology increases from left to right. Relative increase in strength (as \% over weakest lithology at given depth) also indicated. 